\title{
Archaeology in Turkey
}

\author{
MARIE-HENRIETTE GATES
}

This year's report, on archaeological activities in Turkey (fig. 1) during the 1994 excavation season and the 1995 findings that have made their way into public view, illustrates the extent to which long-term projects can become invigorated by new directions, and old issues can be revitalized by new discoveries.* While such developments could be seen as independent trajectories, in the case of Anatolian research they are certainly encouraged by the annual meetings of the Turkish Ministry of Culture's General Directorate of Monuments and Museums. These scholarly forums serve not only as an opportunity for the directors of each project to present the season's findings. Far more significantly, they offer archaeologists the chance to perceive and assess their own research within the broader context of the region and cultural period. Finally, the need to compress a season's results into a 15-minute presentation may also be responsible for the precise articulation of the well-defined research goals that now characterize the majority of these projects. Archaeology in Turkey is proceeding on all fronts toward the end of the century with an energy inspired and coordinated, to no small degree, by these meetings. Indeed, the large-scale projects that are celebrating centennials this decade-Ephesos in 1995, Miletos in 1999illustrate these trends toward wider inquiries into the environmental and cultural background for their urban centers, and are providing excellent but by no means unique models. Specialists in all periods are proving themselves responsive to the challenge of expanding the scope of their investigations.

In this light, several cultural areas are reemerging from a long sleep as dynamic centers for research. Neolithic central Anatolia, for example, long iden. tified with a few isolated and independent sites, can be expected to take on a decidedly fuller personality in the coming years thanks to the excavations at

* This newsletter was written in large part from notes taken at the 17th Annual Archaeological Symposium in Ankara (29 May-2 June 1995), organized by the Turkish Ministry of Culture's General Directorate of Monuments and Museums. I am very grateful to the speakers, to the many colleagues who sent me summaries and photographs, and to Scott Redford, who wrote up the separate entries for the Islamic sites (included here in their own section for the first time). Among my Bilkent colleagues, all of whom provided assistance, A. Ricci, N. Karg, and I. Özgen espe-

American Journal of Archaeology 100 (1996) 277-335
Aşıklı, now in their seventh season, and in the Konya Plain at Çatalhöyük and related Pınarbaşı, reopened on an ambitious scale in 1993. These multidisciplinary projects at last join the long-term investigations around Burdur. They will encourage others to enter this important field, where questions can as yet be framed only in the most elementary terms (where, for example, is the Cappadocian side of the PPNA obsidian network?). On the Aegean coast, the second millennium B.C. is also receiving renewed attention. Together with Troy, Liman Tepe, and Panaztepe, the remarkable Minoan finds from the new investigations at Miletos and the Mycenaean level encountered in 1995 below the Ephesos Artemision promise a future reevaluation in perspectives on both sides of the Aegean.

The neighboring Hittite kingdom also continues to achieve a sharper focus. In a pattern set by the past few years, two new excavations started up at Hittite sites in 1994: at Kınık, source of the Kastamonu metal hoard, and at Kilise Tepe in the Göksu valley, on the route between the plateau and the "Lower Lands." At Ortaköy and Kuşaklı, researchers recov. ered more local color, together with their ancient place-names, Sapinuwa and Sarissa, over the course of the year. These two projects seem fated to proceed in tandem despite their geographic distance: their Storm-Gods were invoked in immediate sequence in, for instance, Šuppiluliuma's treaty with Kurtiwaza (KBo 1.1 - the first tablet in the Keilschrifttexte aus Boghazköi series, published 80 years ago). To these can be added another new city, Tikunani, mentioned in a recently published letter from the Great King Hattušili I to his vassal, its king Tunija/TunipTeššup (M. Salvini in SMEA 34 [1994] 61-80). This letter would represent the earliest-known document attributable to the first named Hittite king. According to Salvini's reading, the tablet was written in

cially helped with Byzantine and bibliographical matters. C.W. Gates attended most of the survey sessions, and it is because of his careful notes that the survey projects can be summarized here. It is a pleasure to express my warmest thanks to all of them, as well as to Tracey Cullen and the $A J A$ office for their encouragement and patient support. I am also grateful to Danielle Newland for revising the map of Turkey (fig. 1), originally drawn by Liesbeth Wenzel. 


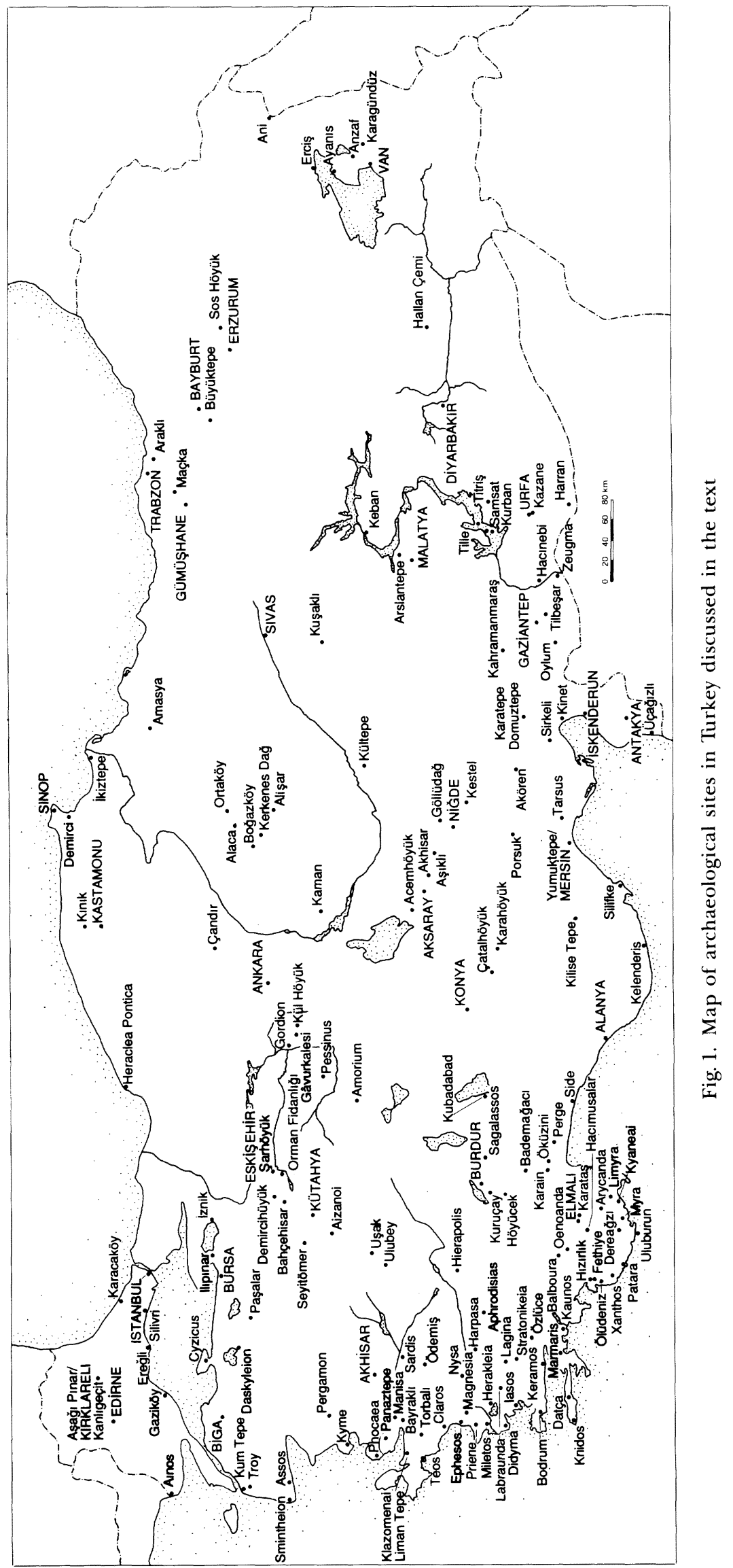


Tikunani while Hattušili engaged in a military campaign at the southeastern reaches of his kingdom. Unfortunately, the tablet on which it was written, together with several others, emerged from the London antiquities market and not in the context of formal excavations. Instead of rescuing a site from anonymity and presenting it with a historical setting, this significant text has merely complicated the difficult puzzle of Hittite geography with yet another query.

The number of antiquities torn from their contexts and transformed, within a second, into orphans of time and place, increases at such a rate that the subject has become familiar in the general press (recently Archaeology 48:2 [1995] 44-56). Perhaps more alarming is the escalation of stealing from known contexts. Six directors reported during the 1995 symposium that their sites, among the most visible classical ones, were the targets of clandestine digging. The archaeological team at Perge, alerted to unofficial activities in the necropolis, found not only a smashed sarcophagus but shovels, hammers, and picks abandoned in the haste of flight by thieves. The Turkish Ministry of Culture has just repatriated, at great expense and after long negotiations, two large, inventoried sculptures from the gardens of the Erdek and Çanakkale Museums, pieces that can only have been removed with heavy equipment. Everyone who participates in this illegal market bears the guilt: the scholars who agree to validate this merchandise; the dealers and their staff who conceal the ugliness of their transactions with elegant showrooms and high-society auctions; and the buyers, no matter how small they imagine their purchases to be.

It is against this backdrop that the resurfacing of "Priam's Gold," after a disappearance lasting nearly 50 years in the storerooms of Moscow's Pushkin Museum and St. Petersburg's Hermitage, should be considered (for bibliography, see below). The circumstances of its discovery in 1873, the photograph of Sophie Schliemann wearing its finest pieces, the very name given to what actually represents at least 18 hoards excavated over two decades - all belong to a Romantic 19th-century perspective. Disputes about the ultimate ownership of these objects should also be understood as stemming from this outdated approach to the past. Better, then, to devote both passion and energy to more pressing obligations. Another Homeric connection, this time appropriate, came to light in 1994 during salvage excavations in a necropolis near Biga, ancient Granikos. In the words of the Turkish press (Cumhuriyet, 18 February 1995), two Late Archaic burials of "incomparable historic value," one of them illustrating a Trojan theme, were saved from the clandestine market by the alertness of Çanakkale's museum director, Nurten Sevinç, who excavated them with exemplary care. The first, a child's marble chamber tomb, contained a wooden table, a lyre with ivory decorations, and leather, all items that would not have survived informal digging. The second is a large marble sarcophagus carved on all sides with reliefs depicting Polyxena sacrificed on the tomb of Achilles, and a lively funerary banquet. Whether this sarcophagus does indeed date to the early fifth century B.C. (and is not Archaizing), one question that will not arise is its provenance and context. Conservation of all the finds was carried out by the Troia project in an exemplary spirit of cooperation.

Finally, 1994 appears to have been the Year of the Horse: Miocene hipparion at Özlüce and in the Sinap formation, Neolithic horse at Aşıklı, late Middle Bronze Age horses at Troy, Medieval horses at Kinet. The results obtained from faunal analysis, together with archaeobotany, trace element analysis, dendrochronology, and other techniques, have assumed their place beside basic archaeological data to be reported as a standard component of a season's findings.

\section{BIBLIOGRAPHY}

Conferences. The 1992 and 1993 annual reports on excavations given at the 15th and 16th archaeological symposia (May 1992 and 1993) were published as XV. Kazı Sonuçları Toplantısı I-II (Ankara 1994) and XVI. Kazı Sonuçları Toplantısı I-II (Ankara 1995), ab. breviated here as KST 15:1 and 15:2 (1994), 16:1 and 16:2 (1995). The 1993 reports on survey and scientific research, XII. Araştırma Sonuçları Toplantısı (Ankara 1995) and X. Arkeometri Sonuçları Toplantısı (Ankara 1995), appear here as AraşST 12 (1995) and ArkST 10 (1995). Reports for the 1994 season, the subject of this newsletter, were presented on 29 May-2 June 1995 at the 17 th archaeological symposium, but will not appear in print until later this year.

Turkish museum personnel also convene annually to present the results of their work, primarily salvage and conservation projects. Their 1994 reports, $V$. Müze Kurtarma Kazllar Semineri (Ankara 1995), are abbreviated here as MKKS 5 (1995).

The Phrygians took center stage at two conferences. Participants from Balkan countries met with Anatolian archaeologists in Ankara on 3-6 June 1995, to discuss "Thracians and Phrygians: Problems of Parallelism," a session organized by Middle East Technical University and the Bulgarian Institute of Thracology. A conference held in Rome by the Institute for Mycenaean and Aegean-Anatolian Studies (16-17 October 1995) focused on the Phrygians in 
their Anatolian milieu. A broader range of Anatolian issues was addressed in a special session at the 1995 ASOR meetings in Philadelphia (18 November 1995).

The following 1996 conferences in Turkey have been announced: "Ceramic Production Centers and Exchange Networks in Hellenistic and Roman Anatolia" (Istanbul, Institut français d'études anatoliennes - late May); "Settlement and Housing in Anatolia through the Ages" (Istanbul, UNESCO-Habitat II/Istanbul University-5-7 June); Third International Congress of Hittitology (Çorum - 16-20 September); "International Symposium on the Ottoman House” (Amasya, University of Warwick/British Institute of Archaeology, Ankara - 24-27 September).

Journals and general publications. The widely circulated historical magazine Toplumsal Tarih included in its August 1995 edition a serious 10-page discussion by N. Asgari, U. Esin, and A. Özyar on the state of Turkish archaeology; it reflects an interest by the general public in issues beyond the more spectacular site presentations of Arkeoloji ve Sanat. More specialized publications have recently devoted entire issues to Anatolian topics: BiblArch 58:2 (1995) (but note that the maps should be used with caution), and TelAviv 21:1 (1994) (on Urartu). Ankara University's Faculty of Language, History, and Geography (AÜ-DTÇF) announces the founding of an annual journal, Archivum Anatolicum, devoted to Anatolian epigraphy and philology (MBA-classical). The first volume, edited by H. Ertem, appeared in 1995.

Since the Newsletter for Anatolian Studies compiles full and frequent lists of publications, the selection here, beyond items listed under individual sites, is deliberately kept brief. The first in the bibliographical series for Bronze Age Anatolian excavations has appeared, and can be welcomed as an essential reference: M. Korfmann, A. Baykal-Seeher, and S. Kılıç eds., Anatolien in der frühen und mittleren Bronzezeit I: Bibliographie zur Frühbronzezeit (TAVO Beiheft B, 73.1, Wiesbaden 1994). For Hellenistic architectural sculpture, one can now consult F. Rumscheid, Untersuchungen zur kleinasiatischen Bauornamentik des Hellenismus (Beiträge zur Erschliessung hellenistischer und kaiserzeitlicher Skulptur und Architektur 14, Mainz 1994). And at the far end of the chronological spectrum for this newsletter, recent discussions of Byzantine issues (many of them archaeological) have been collected by C. Mango and G. Dagron eds., Constantinople and Its Hinterland: 27th Spring Symposium of Byzantine Studies, April 1993 (Society for the Promotion of Byzantine Studies Publications 3, Cambridge 1995).

Museums, exhibits, and catalogues. The Byzantine wing of the Istanbul Archaeological Museum opened in June 1995, an occasion accompanied by an exhibit entitled "Istanbul through the Ages." The Trojan metalwork that has been housed for the past 50 years in Moscow's Pushkin Museum was due to go on display there on 1 March 1996, for one year. The circumstances of its rediscovery are presented by $D$. Easton in "Priam's Gold: The Full Story," AnatSt 44 (1994) 221-43, and "The Troy Treasures in Russia," Antiquity 69 (1995) 11-14, and by M. Korfmann in Studia Troica 5 (forthcoming). A full, detailed catalogue to accompany the "Lydian Treasure," on view at the Museum of Anatolian Civilizations, Ankara, since its repatriation in 1993, is in press.

Festschrifts and memorials. Halet Çambel's colleagues and students have celebrated her many con. tributions to Anatolian archaeology with some works of their own in Readings in Prehistory: Studies Presented to Halet Cambel (Istanbul 1995), hereafter Readings Cambel. (The editors - an anonymous collectivespecify that this will be followed by a true Festschrift for her 80th birthday in 1996.) The colleagues, students, and admirers of Emily Vermeule have also marked her achievements in a volume edited by J.B. Carter and S.P. Morris, The Ages of Homer: A Tribute to Emily Townsend Vermeule (Austin 1995), hereafter Festschrift Vermeule, with many articles on Troy and its neighbors.

A two-volume publication in the memory of Metin Akyurt and Bahattin Devam, young archaeologists tragically killed by a car bomb at Girnavaz in 1991, presents a rich collection of archaeological studies from prehistory to Medieval Anatolia: Studies for Ancient Near Eastern Cultures: In Memoriam I. Metin Akyurt - Bahattin Devam Anı Kitabı (Istanbul 1995).

All archaeologists working in Turkey grieve at the sudden death of Osman Özbek, head of the General Directorate's department overseeing excavations and research, in June 1995 at the age of 43. Although he was responsible for the ultimate processing of all research paperwork, a task that required heroic patience at cyclical times during the year, he remained a master at welcoming each of us and show. ing genuine interest in our projects - even to thanking us personally for our efforts and discoveries. We miss him deeply.

\section{MIOCENE ERA}

Paşalar. The year 1994 marked the concluding season for Berna Alpagut and her international team of investigators, who spent a full decade investigating this Middle Miocene deposit southwest of Bursa. It has proved to be Anatolia's richest site for pri. mates, with specimens representing $7 \%$ of a total 19,000 fossil finds. The identification of stones that 
may have been used as pounders, and a study of primate diet based on teeth, are bringing the behavior of these 15 million-year-old hominids into sharper focus.

Final publications of the excavations and specialized studies, including several dissertations, are in progress, and will appear in a monograph series. All fossil finds have already been recorded in a photographic data base. Reports on the 1992 and 1993 seasons appear in KST 15:1 (1994) 1-22 and 16:2 (1995) 397-425. A general summary, coedited by Alpagut and P. Andrews, has been published in the Journal of Human Evolution 28 (1995) 301-405.

Sinap Formation (Ankara). Survey and salvage excavations were continued for a sixth season in 1994 in the Sinaptepe region $55 \mathrm{~km}$ northwest of Ankara, where hominid remains collected more than 30 years ago had already alerted prehistorians to the region's potential as a bridge between Africa, the Near East, and Europe. The current project, coordinated by Berna Alpagut with Finnish and American colleagues under the aegis of the Ankara Museum's director Illhan Temizsoy, has succeeded in locating geological deposits that form a continuous Middle Miocene to Early Pleistocene sequence spanning 13-14 million years. Over 100 sites have been mapped and in some cases tested with soundings. Of particular interest are the hipparion fossils of both New World and evolved Old World types recovered from several locations and different stratigraphic contexts. Future seasons will begin to investigate the earlier, 15 million-year-old tufa deposits that underlie the Sinap alluvial sedimentary formation. It is hoped that the region will eventually be linked to an intercontinental stratigraphic chronology. Preliminary reports with extensive bibliographical references appear in ArkST 9 (1994) 237-56 and ArkST 10 (1995) 177-99.

Çandır. The Middle Miocene deposits exposed 80 km northeast of Ankara, on the Ankara-Çankırı highway, were investigated during a sixth season by Erksin Güleç and an international team of collaborators. Excavations in the two localities already begun in 1993 produced fossil assemblages of bovids, proboscidae, and carnivores comparable to the previous years' finds, and to the earlier fauna of the Sinaptepe area. A lower jaw of Australopithecene type could relate to Ethiopian hominids. For previous seasons, see KST 15:1 (1994) 63-75.

Özlüce/Muğla. Berna Alpagut followed her brief survey of 1993 in the southern Aegean national park near Muğla with a broader two-month investigation in 1994 of the region's Jurassic formations, in many places threatened by industrial development and lig. nite mines. The deposits belong to the 9 million. year-old Turolian phase known from Mongolia to Spain, and previously documented in Anatolia around the Black Sea. Best represented among the faunal collections from $121 \times 1 \mathrm{~m}$ soundings at Özlüce are hipparion $(35 \%)$, followed by large mammals such as elephant and rhinoceros. The Özlüce fossils are exceptionally complete, and include an elephant apparently trapped in a mudflow. Its western extension, near Mytilene on the island of Samos, has produced similar taxa.

\section{PALAEOLITHIC}

Karain and Öküzini. The concurrent projects at the Palaeolithic caves of Karain and neighboring Öküzini, directed by Işın Yalçınkaya with a large inter. national team, pursued the programs of previous seasons during the 1994 campaign. At Karain, excavations in the "Kökten Hall" continued to define the main stratigraphy and its long span of Middle Palaeolithic cultural components with Mousterian and Levallois characteristics. Surveys in the immediate region have located an open-air site with typical Mousterian tools, probably a camp for the occupants of caves like Karain; and several more caves, primarily Epipalaeolithic but often reused in the classical period.

Results from the Öküzini excavations complemented those of previous years, with further research into the Upper Palaeolithic/Epipalaeolithic phases contemporary with the later occupation at Karain. The larger tools and triangular cores of the lower strata were gradually replaced, in the expected sequence, by Epipalaeolithic triangular microliths. Exceptional 1994 finds that illustrate Öküzini's fine bone tool industry include a wing-tipped arrowhead, a harpoon, spatulas, and an object incised with designs such as a fish. Continued use of the cave in Neolithic times was again attested, in 1994, by a contracted burial accompanied by a large number of stone, bone, and shell beads, a deliberately broken idol-like stone, and a ceramic cup.

Reports on the 1992-1993 seasons and associated surveys appear in KST 15:1 (1994) 23-61 (Karain and Öküzini) and 16:1 (1995) 1-25 (Karain); for ESR dating of Karain tooth enamels and residue analysis of stone tools, see ArkST 9 (1994) 33-37 (O. Çetin and A.M. Özer) and 257-66 (S. Demirci et al.). Caves found by regional surveys are also reported by Yalçınkaya in 1994 Anadolu Medeniyetleri Müzesi Konferansları (Ankara 1995) 55-76, and by H. Taşkıran in AraşST 11 (1994) 227-36. On art at Öküzini, see M. Otte et al., Antiquity 69 (1995) 931-44.

Şehremuz-Samsat. The 1980 s salvage excavations in the upper Euphrates near Samsat have appeared 


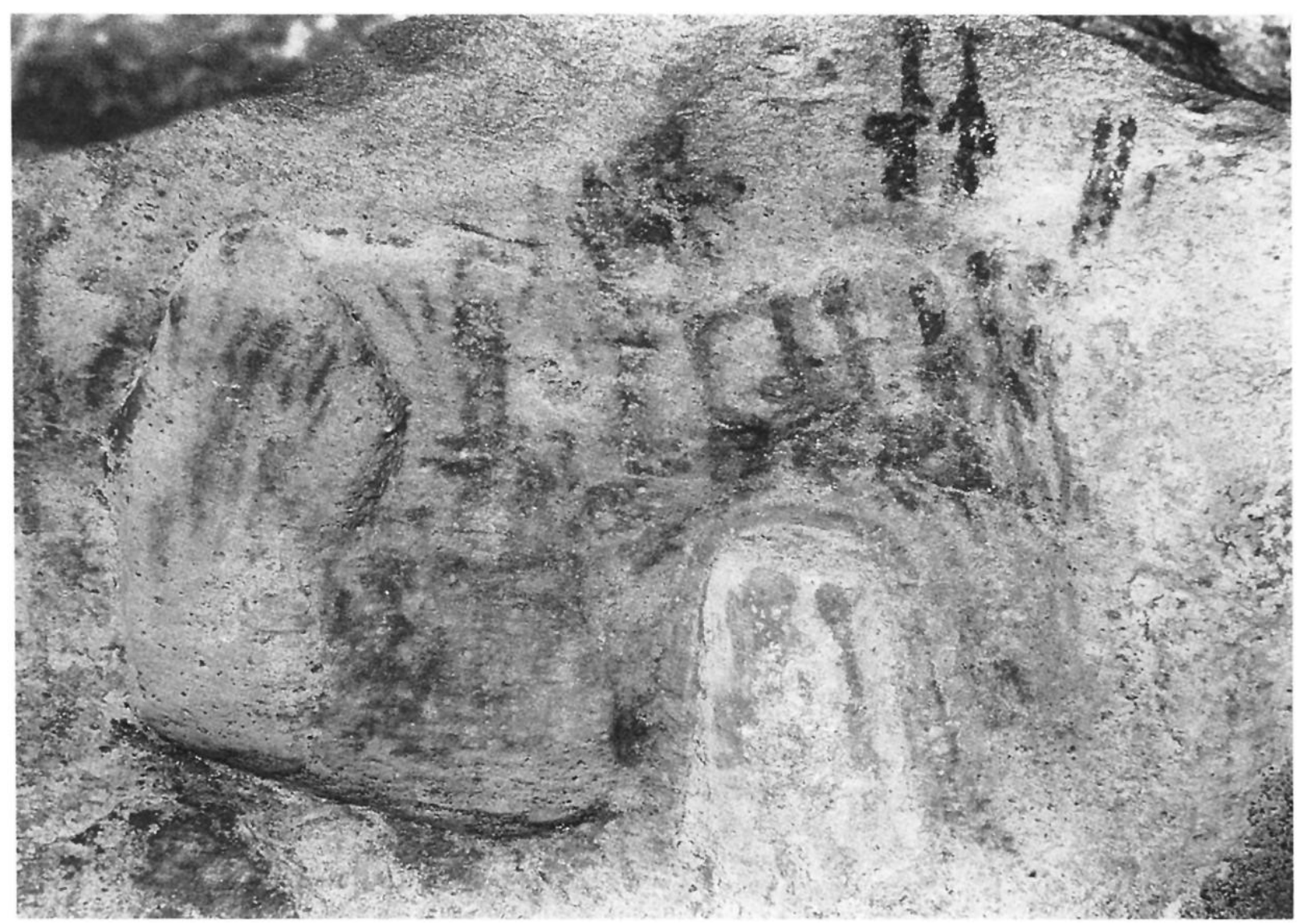

Fig. 2. Latmos-Beşparmak Dağı. Prehistoric cave painting. (Courtesy A. Peschlow-Bindokat)

in a final publication: G. Albrecht and H. Müller. Beck eds., Das Paläolithikum von Şehremuz bei Samsat am Euphrat (Tübinger Monographien zur Urgeschichte 10, Tübingen 1994).

Üçağızl. The analysis of various pigments processed by the Upper Palaeolithic/Aurignacian occupants of this cave site in the coastal Hatay has been published by A. Minzoni-Déroche et al. in Antiquity 69 (1995) 153-58. These pigments, dating to 32,000 b.p., would represent the earliest attested use of ferruginous ore to produce the color red.

Latmos-Bessparmak Dağı. Although prehistoric settlement in the area is barely attested, the 1994 Herakleia survey team directed by Anneliese Peschlow-Bindokat discovered, in the northern reaches of the mountains, two small rock shelters decorated in red and brown pigments with figural scenes. The better preserved of the two (fig. 2) represents a number of upright figures, primarily women with exaggerated buttocks and breasts, and at least one clear scene of sexual intercourse. This type of parietal art is otherwise unknown in central and Aegean Anatolia. It could date as late as the Chalcolithic period; but context and subject would per- haps place it much earlier, even into the Upper Palaeolithic (10,000 B.C.). A preliminary publication, with illustrations, appears in AntW 26 (1995) 114-17.

Classical remains recorded by the Latmos area sur. vey are presented below under "Classical, Hellenistic, and Roman Caria: Herakleia am Latmos."

\section{EARLY NEOLITHIC}

Hallan Çemi. The 1994 excavations conducted by Michael Rosenberg, University of Delaware, at this largely aceramic site on a tributary of the Batman River reinforced the results of the previous three seasons, while extending its occupational phases from two to three and perhaps four building levels. Throughout these phases, circular structures enclosed the same open activity area, although their building materials and architectural details changed noticeably. The settlement was smaller (well under $0.5 \mathrm{ha}$ ) than earlier estimates indicated, and perhaps appropriate for several generations of a modest ex tended family living in the eighth millennium B.C. They would relate to their contemporaries in the Jebel Sinjar and upper Tigris of northern Iraq. Dr. Rosenberg kindly reports: 
"The 1994 excavations succeeded in coordinating the stratigraphic relationship for three and possibly four architectural levels to the north and south of the central area that remained open throughout the site's occupation. The two upper levels, already known from earlier seasons, could be readily distinguished by their different construction techniques. In the latest phase, the walls of the two semisubterranean circular structures were built of upright sandstone slabs and wooden posts. In contrast, the preceding, second phase used pebble/cobble walls held together with mortar. These are now represented by four structures, three of them circular and carefully paved with sandstone slabs, and the fourth smaller, unpaved, and U-shaped. In 1994, a third and earlier level was also found to share all of the features of the second phase, including the two types of buildings. Evidence for the presence of circular wattle-and-daub structures in levels 2 and 3 was provided by round plastered platforms, postholes, and one burnt wood superstructure. At the close of the season, traces of a fourth level also began to appear. The two structures of level 1 are still considered public because of their furnishings. All of the level 2 and 3 buildings would now appear to be domestic.

"The local ground stone industry, now familiar from previous seasons, included an unfinished pestle that was abandoned when the stone split, unfinished bowls and bowl blanks, as well as what may be a spindle whorl. Bone artifacts still consist primarily of awls, in addition to toggles, polished boar tusks, and a second example of a decorative snake-shaped piece.

"The inhabitants of aceramic Hallan Çemi relied especially on pulses and nuts (such as wild almonds) for their diet, not on cereals and wild grasses. They were, however, experimenting with pig domestication, again indicated by the 1994 data, as well as practicing selective hunting of male sheep and goats.

"The relationship between the aceramic settlement and the ceramic material found in 1993 on the south side of the mound was investigated in 1994 in a test sounding, down to a depth of $2 \mathrm{~m}$ without reaching either an underlying aceramic level or sterile soil. Since the pottery and other finds in this deposit were sporadic and not associated with any architecture or features, they may reflect intermittent camping. The present evidence therefore sug. gests a discontinuity along the mound's southern area, which should not be included when calculating the size of the earlier settlement."

The 1992-1993 season reports are published in KST 15:1 (1994) 123-29 and 16:1 (1995) 79-94, and a general report in Anatolica 20 (1994) 121-40. For 1994, see Anatolica 21 (1995) 1-12.

Aşılı Höyük. During the sixth excavation season at this exceptional aceramic site on the banks of the Melendiz, east of Aksaray and close to rich obsidian sources, Ufuk Esin deepened the sounding on the mound's high north slope, and extended the horizontal exposure of the upper settlement toward the south and northeast. The northwest sounding illustrated further the homogeneous and conservative nature of this culture: house walls were rebuilt precisely on top of their predecessors (by 1994, as many as eight successive rebuildings had been revealed), their single-room compartments at times indented to accommodate neighboring units so that no space was wasted between the individual structures. On top of the mound, the large south building with casemate walls revealed more of its atypical architecture. It now includes a court enclosed by a stone and mudbrick wall and paved with large mudbricks (the earliest attested in Anatolia), and would appear to have served a public, perhaps religious, function. A pebbled street running along its northern side was followed to a fork and its northern and eastern extensions. The houses lining the pebbled street in the northeastern sector were exceptionally constructed of clay slabs mixed with fieldstones, the floors and walls often painted red, and the units consisting of as many as three rooms. One of these was divided by narrow partitions into storage bins, whose contents may be retrievable with microsoil analysis. A large refuse pit was also found in this district off the pebbled street. As in the previously excavated areas, a few burials were located under the house floors.

The 1994 excavations again produced large quantities of single and spacer beads in a variety of materials, some imported: stone, bone, solid heat-treated copper and cold-hammered rolled sheets of natural copper (from Ergani?), and seashell from the Mediterranean. The obsidian toolkit includes triangular microlithic arrowheads retouched on one side, perhaps a link, like the architecture, to Cafer Höyük. Botanical finds continue to favor a broad range of wild grasses with few cultivars, suggesting little interest in agriculture. The faunal assemblage, also wild, can now be expanded to include the horse. Thus this broad and sophisticated site, consistently dated by radiocarbon and ESR to the eighth millennium B.C., apparently relied on the region's natural bounty for food while bringing in exotic products from distant places.

For the 1992 preliminary report, see KST 15:1 (1994) 77-95; specialist studies on human remains 
and botanical specimens (hackberries) appear in ArkST 9 (1994) 23-31 (M. Özbek) and 101-109 (S. Gülçur), respectively. Esin considers the Aşıklı metal finds and their evidence for early metallurgy in Readings Cambel 61-77.

Pınarbaşı/Konya Plain. Survey and several selective soundings carried out in 1993 and 1994 by Trevor Watkins and Douglas Baird as part of the new project at Çatalhöyük have succeeded in providing it with long-awaited relatives and antecedents in the Konya region. Several rock shelters and open-air sites were identified at Pınarbaşı, near the small Süley. manhacı lake at the base of Kara Dağ, $20 \mathrm{~km}$ from the main mound. Soundings in one of the shelters traced a long history of use (burials and hearths) from Epipalaeolithic (pre-8000 B.C.) to aceramic and ceramic Neolithic times, the latest level being parallel with Çatalhöyük. The Epipalaeolithic period was also tested at the open-air site recorded in 1993 on the lake edge. It is characterized by a chipped stone industry using an exceptional percentage of obsidian $(80 \%)$, and a wide range of fauna but-despite the lake - few fish. Such findings, together with the geomorphological studies being undertaken in conjunction with the project, promise to clarify the environmental and cultural setting in which the developed Çatalhöyük Neolithic phase occurred.

For the 1993 survey, see AraşST 12 (1995) 421-27 and AnatSt 44 (1994) 13-15; the 1994 session is sum. marized in British Institute of Archaeology/Ankara Research Reports 1994, 14-17.

\section{LATER NEOLITHIC}

Yumuktepe/Mersin. During the second season of the new Yumuktepe excavations codirected by Veli Sevin (historic levels) and Isabella Caneva (prehistoric levels), trenches were again opened in the area of Garstang's northwestern Trench A to correlate the current project and the present state of the mound with his discoveries of over half a century ago. An upper $10 \times 10 \mathrm{~m}$ trench uncovered portions of a massive burnt mudbrick building (6000 B.P.) that can be assigned to Garstang's Chalcolithic level XVI and is probably a western extension of his fortified bar. racks. Several rooms with doorways and two windows appear to have been subdivided at a later stage by flimsy partitions that suggest a long duration for this level. In situ pottery consisted mainly of red and brown handmade bowls, and a small number of vessels painted with yellow and brown zigzags. Ubaid types were much rarer than indicated by Garstang. In a lower, Neolithic trench to the south, a level somewhat below Garstang's level XXVII produced the stone foundations of a small buttressed structure whose walls, probably pisé, were plastered white.
Thin gray burnished pottery, some red on white painted wares, and infrequent chipped stone tools (with some obsidian) characterize this later Neolithic assemblage. The recutting and continuation of Garstang's stratigraphic sounding demonstrates that below levels XXIX-XXX lie another $7 \mathrm{~m}$ of occupational deposits down to sterile soil, with several burnt architectural levels, and stone foundations at the earliest stage of the settlement (radiocarbondated to ca. 6000 B.C.). Lentils, emmer wheat, olives, almonds, and the standard range of domesticated animals, supplemented by some fishing and hunting, suggest a well-fed population.

Excavations on top of the mound, which has been considerably modified by recent terracing, recorded three levels of large Medieval buildings that made liberal use of classical spolia including columns. Their stratigraphy requires modifications to the scheme published by Garstang. A preliminary report on the entire 1993 project has been published in $K S T$ 16:1 (1995) 27-41.

Çatalhöyük. During a second season preparatory to the resumption of excavations, Ian Hodder and an interdisciplinary team completed their topographic survey of the 13.5-ha East Mound, and the later 8.5-ha West Mound. Systematic surface collection also delineated more clearly the mounds' chronological phasing. The latest Neolithic levels are located on the eastern rise of Chatal East. Classical and Byzantine settlements are found on the southern side of Çatal East, and on the eastern side of Çatal West; a Byzantine lower town also extends from the western mound across the fields toward the east over a 10-ha area. Cores into the deposits below Mellaart's earliest level (XII) indicate a further 4-5 m of Neolithic occupational deposit.

Surface scraping and remote sensing (magnetometer) were especially informative in a $40 \times 40 \mathrm{~m}$ square on the high northern area of Çatal East, where irregular houses were found clustered on either side of a narrowing alley. Scraping also determined that the Neolithic inhabitants, estimated at 5,000-10,000, were dumping refuse into the depressions on the site, while for the most part building their new houses only on earlier wall foundations. Continued cleaning of the 1960s' excavation areas, and recording of their sections, again included microsoil analysis of house floors. Results suggest that the "shrines" originated as domestic buildings and assumed more specialized functions through time. New studies undertaken on the ceramic and flint finds from the earlier excavations are also attempting to assess whether the assemblages from the "shrines" and houses differ significantly.

The ancient landscape around Çatalhöyük is re. 
emerging thanks to further geomorphological study. The site originally stood on or near the banks of the Çarşamba River, whose alluvial deposits ensured fertile fields for its farmers. At some stage, a channel was dug to bring water between the two mounds. It remains to be discovered when the river changed course away from the site, and the effect this might have had on the site's occupation. A summary of the 1994 season can be found in British Institute of Archaeology/Ankara Research Reports 1994, 11-14; for 1993, see AnatSt 44 (1994) 10-13.

For Neolithic and earlier sites in the Çatalhöyük area, see above, under "Early Neolithic: Pınarbaşı."

Bademağacı Höyük. Refik Duru conducted a second excavation season in 1994 on this large mound, well situated on the route leading inland from the coast at Antalya up to the Anatolian plateau. A 6-m deep sounding on the more promising northeastern side confirmed the previous season's occupational phases: EB I-II, preceded by a long Neolithic sequence of domestic architecture. The pottery, of local type distinct from the Kuruçay/Höyücek culture, is unpainted, and includes tall bag-shaped jars with tubular handles. Traces of a modest Early Chalcolithic settlement were again found only in the southern part of the mound, as indicated by red wares with festoons and chevrons in white paint. The site's reoccupation in the EB I period is marked by pottery resembling the earliest EB material from Beycesultan, large structures with stone foundations, and perhaps a fortified enclosure. Cobbling at the foot of the northeastern slope may be part of a rampart. For the 1993 season, see KST 16:1 (1995) 69-77.

Kuruçay. The first of the final reports on this Neolithic and Early Chalcolithic site near Burdur has been published by R. Duru, Kuruçay I: 1978-1988. Kazıların Sonuçları. Neolitik ve Erken Kalkolitik Çăg Yerleşmeleri (Ankara 1994).

Orman Fidanlığı. Turan Efe, Istanbul University, succeeded in his efforts to correlate the fifthmillennium contacts between Anatolia and the Balkans with a final season at this site southwest of Eskişehir, where quarrying and deep erosion layers made excavations exceptionally difficult, and stratified remains came as the reward of both patience and persistence. He kindly reports:

"Salvage excavations were brought to a close in 1994 at the end of the third campaign. Seven levels were distinguished (I-VII, with I the earliest) in an excavated area of $320 \mathrm{~m}^{2}$.

"The finds from levels I through $\mathrm{V}$ form a single continuum with clear internal development. Because the pottery from these five levels reflects a new assemblage, otherwise known only from survey in the upper Porsuk valley, we have chosen to call this the
"Porsuk Culture." Houses were freestanding, built of mud or mudbrick, some on stone foundations. Bricks are first attested in level III. A one-room structure of mudbrick on stone foundations from level IV was apsidal.

"The pottery of the Porsuk culture, which includes pre-Vinča elements, is comprised mainly of burnished wares, slipped wares, and painted wares. Characteristic open forms include shallow bowls and plates, deeper bowls with everted rims, and carinated bowls. Other typical vessels consist of jars with cylindrical necks, and squat-bellied pots with everted rims and vertical lug handles. The dark-burnished vessels are often decorated with grooved or punctate bands on their shoulders; some have surface rippling. Knobs are frequently attached to the carinations. Some of the slipped wares have linear patterns 'painted' in the same reddish slip. Another ware class, painted with red and/or black spiraloid patterns on a white or cream ground, recalls Starčevo motifs.

"Figurines are also characteristic of the Porsuk culture. The earliest, from level I, with their arms folded and meeting mid-chest, can be compared to Hacılar I examples. For the later and more stylized figurines, only the large buttocks are carefully modeled; otherwise, the figures are shown armless, and the two legs are separated only by a shallow vertical incision at the front and back. Similar types occur at Ilıpınar VI (mid-fifth millennium) and in the Balkans. Other finds include chipped stone tools, grinding stones and pestles, marble bracelets, groundstone celts, and bone tools.

"Level VI, investigated in a very limited area, should be linked to the succeeding level VII rather than to the earlier phases. With level VII, the ceramic assemblage changes significantly from the preceding Porsuk cultural phase, implying a gap between them. The later phase is characterized by black-burnished wares with generous straw temper and white-painted decoration; black-topped bowls with slightly incurved rims, or S-profiles; and horn-shaped handles on jars and round-bellied pots. This pottery shows affinities with Yazır Höyük and Beycesultan Late Chalcolithic 1-2, and provides a terminus ante quem for the Porsuk culture. It would ultimately link the stratigraphy of contemporary sites in the Marmara region Ilıpınar, Yarımtepe, Toptepe - with western Anatolia and Beycesultan. A copper pin with a double-spiral head (fig. 3) and a copper piercing tool from level VII represent the earliest metal implements yet found in northwestern Anatolia."

Ilıpınar. Jacob Roodenberg resumed his research on Neolithic and Chalcolithic Balkan-Anatolian connections with a seventh campaign in 1994 at this early farming community east of the Sea of Marmara. Ex- 


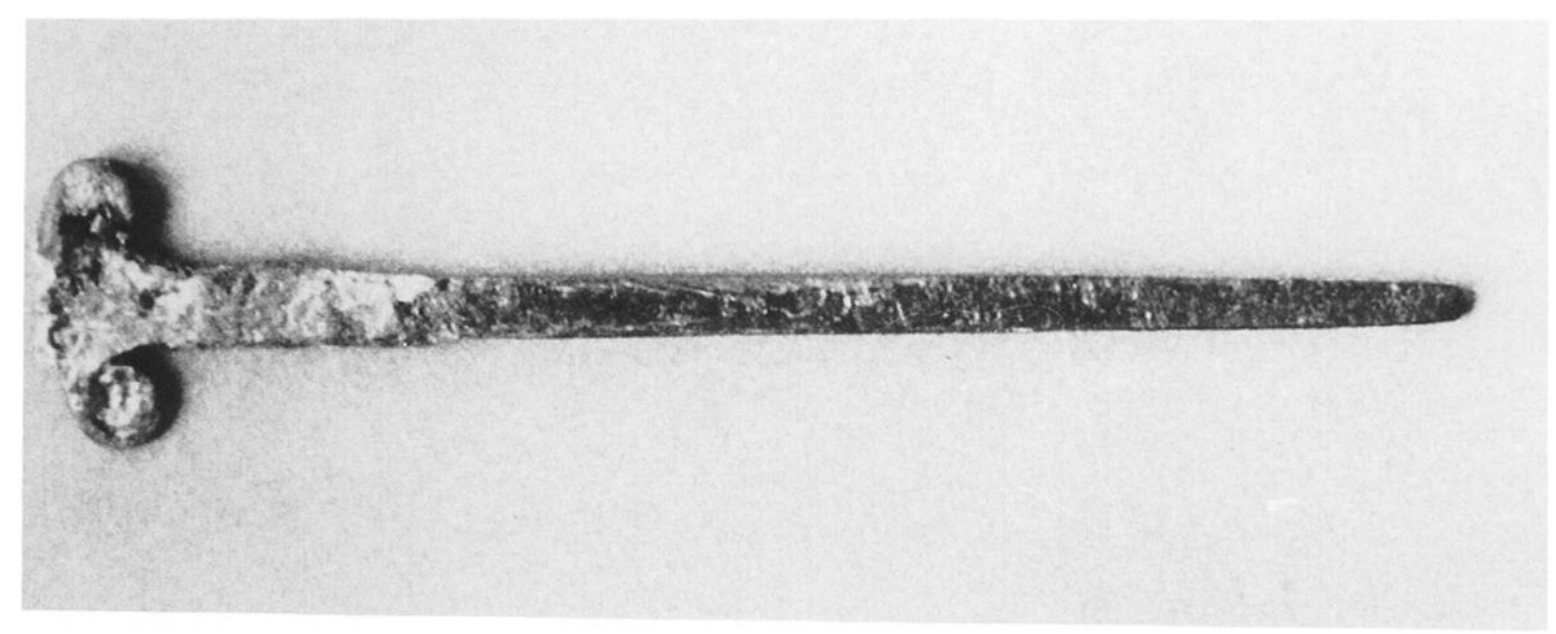

Fig. 3. Orman Fidanlığı. Level VII: copper pin. Length ca. 7 cm. (Courtesy T. Efe)

cavations continued in the northern and western squares, and confirmed the site's overall phasing, which is complicated by spiral stratigraphy and the slippage of upper levels into the western gully. Further study of the late sixth-millennium wattleand-daub burnt house in the large trench W 12/13 (level IX rather than X as in AJA 98 [1994] 253 and 255 fig. 3) suggests that it contained an inner platform, another link with the Balkans. This one-room house remained the standard type at Ilıpinar for 500 years. Below it, in level X, were found 15 burials that also bear no resemblance to the contemporary Anatolian (intramural) tradition. The children, young adults, and one 60-year-old woman were placed on their left or right sides, flexed, without fixed orientation, accompanying gifts, or a discernible burial pit. This level marks the earliest occupation at the site, founded on virgin soil.

The level VI transition to the Early Chalcolithic period, when mudbrick replaced wattle-and-daub for the typical one-room house, was investigated in the western squares, at the edge of the ancient settlement. A new cultural level, VB, was defined here, together with an unprecedented compartmentalized building fronted by a courtyard. A row of jars and plastered reed containers, originally shaded by an awning, was found in situ along the court's back wall. Inside the doorway were two separate kitchen areas. Although the back of the building was destroyed by plowing, enough remained to indicate that it was built on several terraces rising up the slope. The building and its associated level would date to the mid-fifth millennium, a century or so later than level VI. It is discussed in Orient Express 1994:3, 69-71.

For the EB settlement at Hacllartepe, and its cemetery at Ilıpınar, see below, under "Chalcolithic and Bronze Age: Western and Coastal Anatolia."

Kum Tepe. As part of the Troia Project and with the cooperation of the Çanakkale Museum, another $40.5-\mathrm{m}^{2}$ area of the large pre-Troy I settlement was exposed immediately below the modern surface. Manfred Korfmann, Tübingen University, kindly reports:

"Levels and finds of the Kum Tepe IA phase (as the new project now refers to the Kum Tepe A period) were uncovered below the IB deposits as in the 1993 trenches. Less expected was the discovery that settlement IA was founded on top of a cemetery with flexed burials of pre-Karanovo type, early in the Balkan Neolithic sequence (earlier fifth millennium B.C.). This cemetery represents the first evidence for an Early Neolithic occupation in the region, which must have played a key role in northwest Anatolian. Balkan interconnections."

Accounts of the 1993 and 1994 seasons appear as part of the Troy preliminary reports in Studia Troica 4 (1994) 1-50, KST 16:1 (1995) 239-62, and Studia Troica 5 (forthcoming).

Kulaksızlar-Akhisar. Rafet Dinç surveyed a marble workshop in the region of quarries between Akhisar and Sardis. Fifteen different types of blanks and unfinished pieces include stone bowls and possible figurines. The workshop could date to the period of Kum Tepe IA, or as late as the Early Bronze Age.

Aşağı Pınar/Kırklareli. The joint Turkish-German project led by Mehmet Özdoğan and Hermann Parzinger to investigate early Balkan and northwest Anatolian connections in Thrace carried out a second season of excavations at Aşağı Pınar in 1994. The site maintained its Balkan cultural affiliations from Neolithic (viz. Chalcolithic in Anatolian chronology) to Hellenistic times. Three stratified levels of domestic structures built of wood, with interior platforms and large circular hearths, are associated with Karanovo III-IV pottery spanning all phases of the Balkan Middle Neolithic period (later fifth 


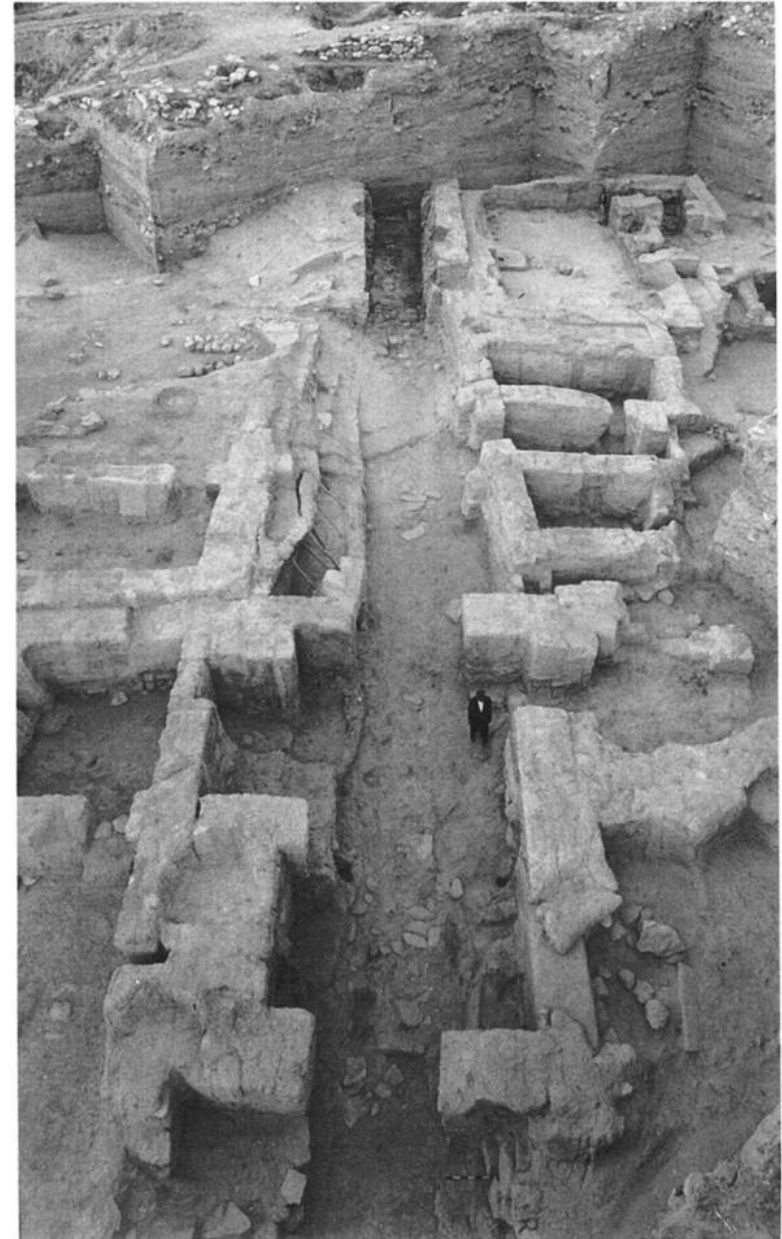

Fig. 4. Arslantepe-Malatya. Building IV from the south, with gate in foreground and Temple $B$ in upper right, with figure for scale. (Courtesy M. Frangipane)

millennium B.C.). Malachite from the second level suggests that metalworking took place here. In the earliest phase a flexed burial without grave goods was found, a tradition shared with Ilıpınar. The site was reoccupied, after a long hiatus, during the Bronze Age. Finally, the Hellenistic tumulus that crowns the prehistoric mound, built up from materials mined from the earlier deposits, was surrounded by pits containing funerary gifts and sacrificed animals $-\mathrm{a}$ Balkan funerary practice. A report on the first season has been published in KST 16:1 (1995) 43-67. Özdoğan discusses northwest Anatolian Neolithic chronologies in Türk Tarih Kurumu Kongresi 40:1 (1994) 69-79, and Readings Cambel 41-59.

For excavations at the later Chalcolithic Kanlıgeçit, see below, under "Chalcolithic and Bronze Age: Western and Coastal Anatolia."

\section{CHALCOLITHIC AND BRONZE AGE}

Southeastern Anatolia and Cilicia

Arslantepe-Malatya. The 1994 campaign focused

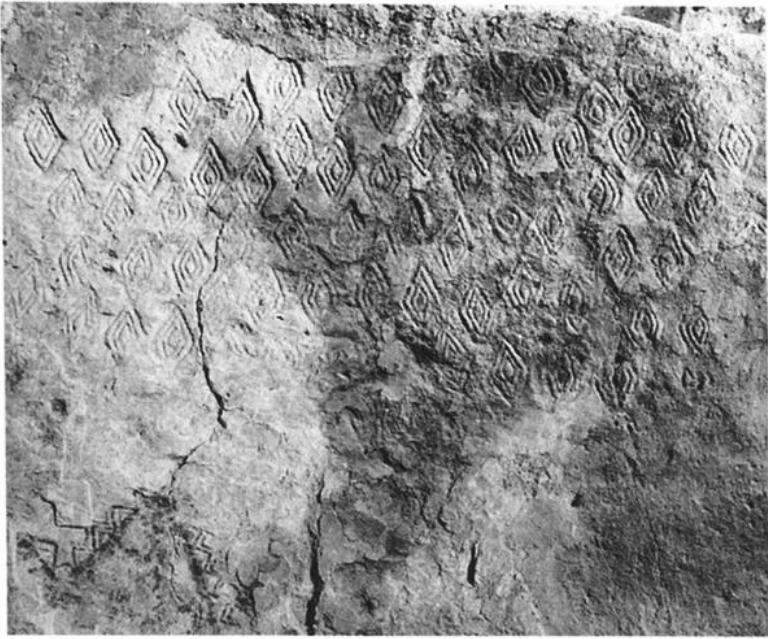

Fig. 5. Arslantepe-Malatya. Building IV. Corridor wall with impressed and painted decoration. (Courtesy M. Frangipane)

its energies on the huge temple-palace complex known as Building IV, dated to the late fourthmillennium Uruk-affiliated level VIA (EB IA). The 35-m-long corridor that linked the units of this complex, and Temple B at its north end were excavated down to their floor levels, which had not been reached in 1993. Director Marcella Frangipane, Università di Roma, generously provided illustrations for the following summary.

The long corridor (fig. 4) allowed communication between the independent structures that made up the complex, and drainage via a water channel under its floor. At its lower south end, behind a monumental gate, it gave access to a series of storerooms. The corridor's inner sector, the approach to Temple B, was roofed, plastered, and decorated with impressed lozenges and geometric motifs in red paint (fig. 5), resembling Uruk fashions. It was later replastered and revetted with wood panels to secure a second story. Burnt beams lying on the floor of the corridor give hope for a dendrochronological date.

Temple B, $15 \times 12 \mathrm{~m}$, probably two stories high and bipartite in plan (fig. 6), proved also to be fur nished with twinned cult items: two altars or plat forms, pairs of clay basins, and two offering tables in the center of the cella. The entrance was on the east side, away from the corridor, through a wing of small rooms that contained kitchen equipment such as mortars and pestles, but no pottery. Large ceramic vessels in the cella were concentrated in the northwestern corner of the room across from the entrance, and opposite the far altar. They included several unique types in local wares but Uruk shapes: two large jars in period VII fabrics (red with chaff temper), a red-burnished carinated jar, and a pair 


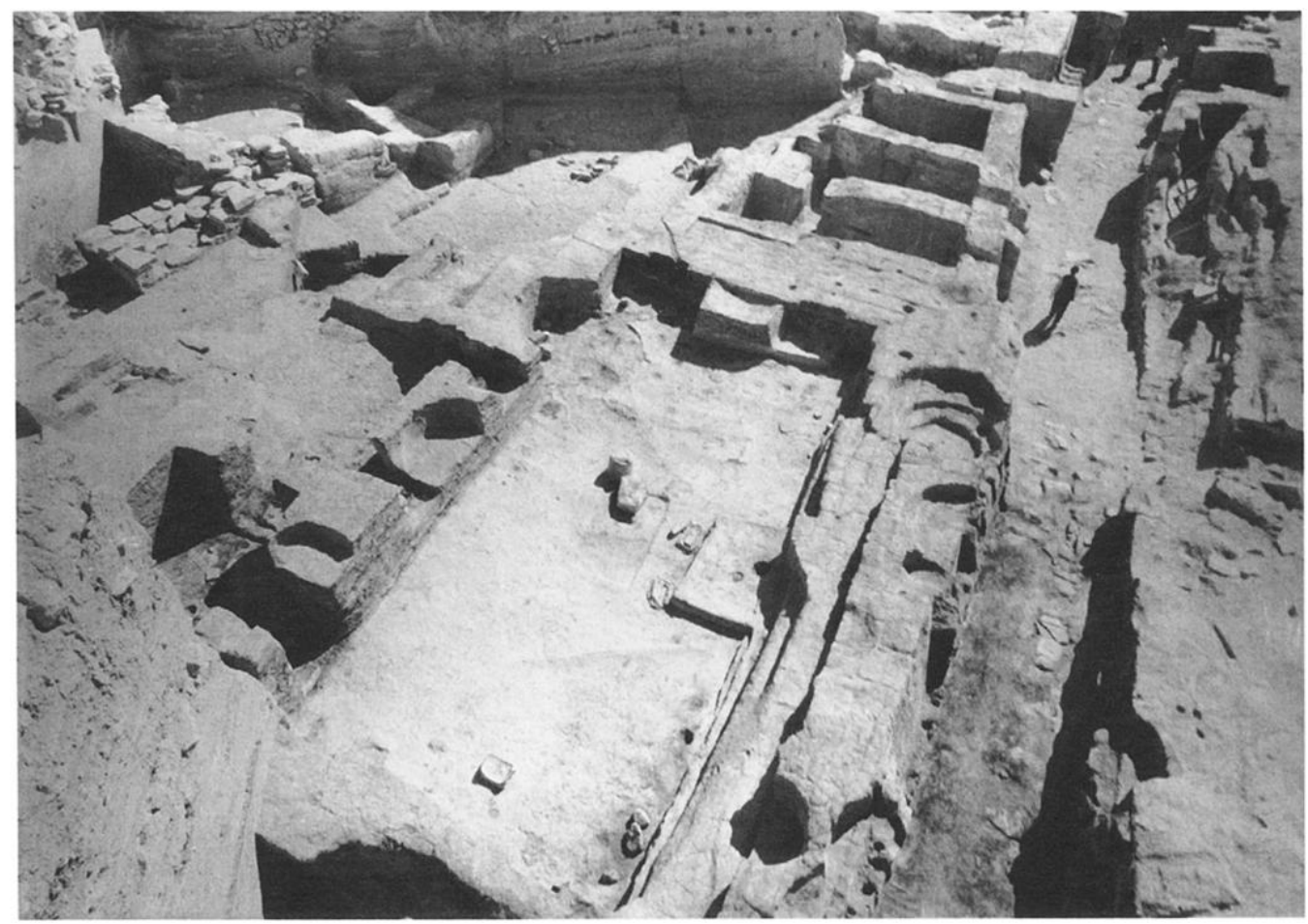

Fig. 6. Arslantepe-Malatya. Building IV, Temple B from the north, with corridor on the right. (Courtesy M. Frangipane)

of wine bottles (fig. 7). Three tall-stemmed bowls were placed in front of the altar against the long wall. The vessels beside the other altar still contained food residues. A dozen more sealings (for a total of 50) were recovered from the building, especially from one of the side rooms where they appear to have fallen off a shelf near the window.

Investigations in the area of Temple A, which lies to the west beyond Building IV, confirmed that it was a later construction (as indeed suggested by their different alignments) and could not be reached by the long corridor. In front of the temple, an enclo. sure with broad stone foundations formed a room reached by a flight of stone-paved steps. The room was burnt and evidently looted. The doorpost and its copper alloy door socket, held in place with nails, were found in situ. This extravagant use of metal, together with numerous other metal finds dating to this phase, give some measure of the resources and prosperity of the inhabitants of level VIA.

The 1992 and 1993 preliminary reports appear in KST 15:1 (1994) 211-28 and 16:1 (1995) 165-76.

Hacinebi Tepe. Further investigations into the interaction between fourth-millennium local entrepreneurs and Mesopotamian businessmen in the upper Euphrates valley were carried out during a third rescue season by Gil Stein, Northwestern University, and codirector Adnan Misır, director of the

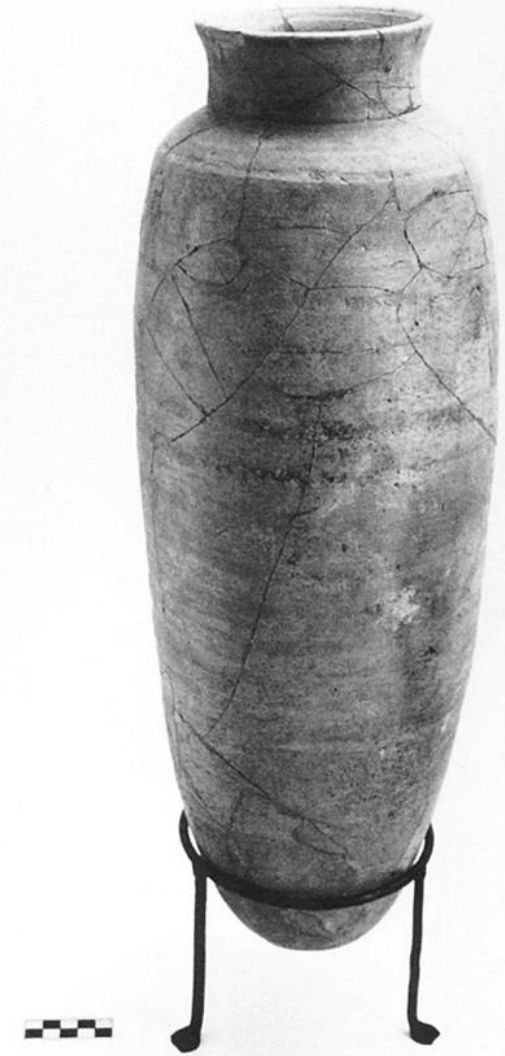

Fig. 7. Arslantepe-Malatya. Wine jar from Temple B, Late Uruk period. (Courtesy M. Frangipane) 
Şanlıurfa Museum. They kindly provide the follow. ing assessment:

"The 1994 excavations continued to widen the previous operations in the northern, southern, and western areas of the 3.3-ha mound for an excavation area of $600 \mathrm{~m}^{2}$. The upper level of all three areas produced further evidence of the site's last major settlement, dated to the Achaemenid/earlier Hellenistic period. Large-scale public buildings in the western and southern trenches, and the stretch of defensive wall uncovered in 1993, would suggest that the site's strategic location on the major east-west river crossing at Birecik was being fully exploited as a military outpost. The buildings, whose mudbrick walls on stone foundations were in places preserved to heights of $1.5 \mathrm{~m}$, had been carefully cleaned out and abandoned. They can be dated nonetheless to the late fourth-early third century B.C. by a Hellenistic coin found on a floor; and stratigraphically by intrusive storage and trash pits, containing late third- and second-century B.C. pottery. Evidence for some presence at the site during the century preceding Alexander is indicated by the burial gifts in a tomb excavated in 1993, in particular a signet ring in Achaemenid style.

"The Late Chalcolithic fourth-millennium settlements that represent Hacinebi's only other occupational phases underlie the Hellenistic buildings in all areas of the site. The deposits are $5 \mathrm{~m}$ deep. They are clearly separable into an earlier and later phase to which the 1994 season was able to assign calendar dates backed by radiocarbon samples. Phase $B$, the "contact phase," is characterized by Uruk-affiliated artifacts such as clay cones, bullae, and tokens. These occur in contexts with local wares that roughly correspond to the Amuq $\mathrm{G}$ period, but belong in fact to the distinct ceramic horizon known from Arslantepe VIA [where it is classed with EB I] and Kurban VIA. Hacinebi's earlier, "pre-contact phase," or phase A, at present the first-known occupation of the site, would be equivalent to Amuq $\mathrm{F}$ and especially Arslantepe VII, before the appearance of Mesopotamian traits.

"During phase B, whose long duration is indicated by modifications to many of the structures belonging to several architectural levels, the northern area of the mound may have served as the residential district for a small enclave of foreign merchants. The concentration of Uruk ceramics, administrative artifacts, and other characteristic Uruk items such as cruciform grooved stone weights and clay sickles ap. pears greater here. Below residential architecture dating to the middle and end of the phase, the 1994 season exposed most of a large stone/rubble platform, ca. $8 \times 9 \mathrm{~m}$ and $2.4 \mathrm{~m}$ high, that underwent a series of repairs and remodelings. It was expanded at some point by a lower terrace with a connecting ramp and staircase. No trace of the superstructure was preserved, but the scale of the platform would have suited a public building originally set in an open area. The first phase of the platform can be associated with ash tips containing local ceramics and Anatolian-style stamp seals. Later, domestic rooms were built up against the platform's northern face and eventually on top of it as well. A large pit cut into these later buildings still contained local pottery and stamp seal impressions depicting mainly cervids and lions, motifs common to this region as known from Arslantepe and Değirmentepe. A limestone stamp seal in this style, as well as two blanks, gives a firm local context to this recording system. An influx of foreign goods and practices marks the end of the phase, and is best illustrated by the contents of a large pit: pottery exclusively of Uruk type, two cylinder seal-impressed jar stoppers, a tablet blank, and a fragmentary clay tablet with a cylinder seal impression but no preserved notations (fig. 8). In addition to these, a stamp sealing of local type suggests that, in the pit at least, the two recording practices were contemporary.

"Early phase B structures were also excavated in 1994 on the southern slope of the mound, where a stone platform built late in the pre-contact phase

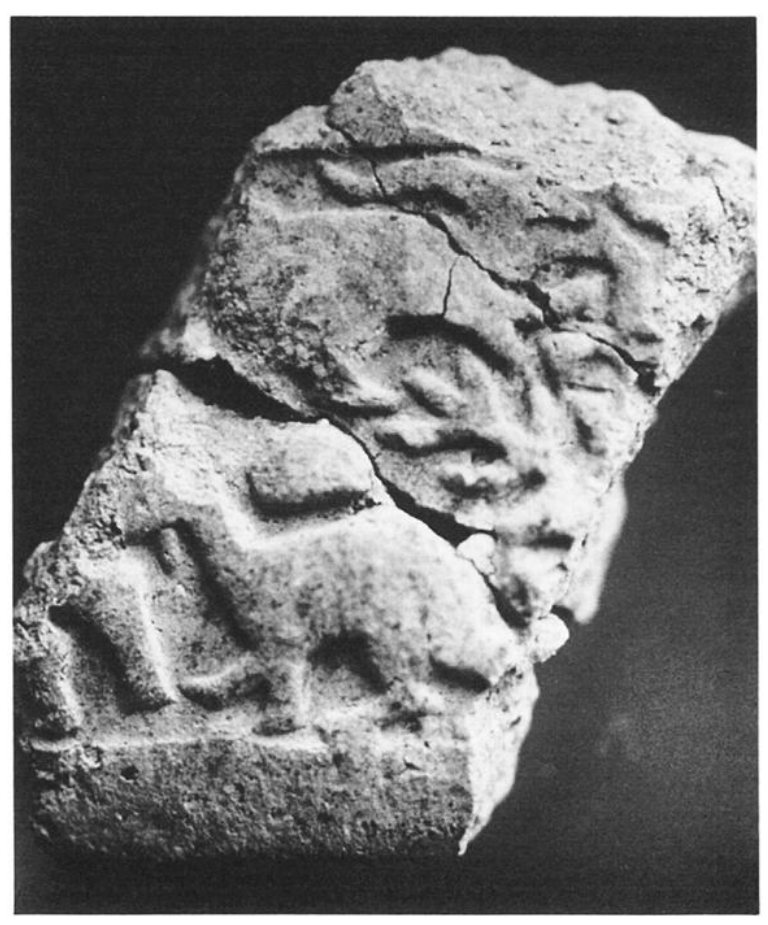

Fig. 8. Hacınebi Tepe. Tablet with cylinder seal impression, phase B. (Courtesy G. Stein) 
continued to be used in the ensuing period; and, near it, the stone foundations of a monumental wall with broad niches/buttresses on its inner face. It too was later subdivided by flimsy walls into narrow rooms. Late in phase $B$, these were in turn cut into by pits, one of them filled with beveled-rim bowls. It would appear that the size of the settlement was decreasing over the course of phase $B$.

"Phase A, defined as the pre-contact Late Chalcolithic period of the earlier fourth millennium, was exposed during the 1994 season in the northern and western areas of the mound. In the north, it consisted of terracing and a large wall set into the natural hill on which the settlement was founded. This terracing was built over during phase $\mathrm{B}$, in particular by a later terrace east of the one described above. The west area produced a well-stratified sequence of building levels, all dating to phase A, and including two narrow rooms, perhaps for storage, beside a courtyard house excavated in 1993. A ceramic mold with copper residues, and a copper chisel, both from the house, attest to metalworking in early Hacinebi; and a stamp seal impression once used to secure a woven basket shows an early interest in formal administration.”

The 1992 and 1993 seasons are presented in KST 15:1 (1994) 131-52 and 16:1 (1995) 121-40. See also Stein et al., supra 205-60, in this issue of AJA. A preliminary analysis of the pottery has been published by S. Pollock and C. Coursey in Anatolica 21 (1995) 101-42.

Titriş Höyük. Remote sensing and excavation continued for a fourth season at this large site (now estimated at $43 \mathrm{ha}$ ) in the upper Euphrates valley north of Urfa. As previous seasons had already demonstrated, Titriş conformed with the typical EB III-IV Syro-Anatolian urban configuration of a lower town and suburbs extending across a broad area at the foot of an acropolis mound. Since these lower districts were not reoccupied after the close of the period and their remains lie just below the surface of open fields, the site is ideally suited for research into the dynamics of a third-millennium B.C. residential center. Guillermo Algaze, University of California, San Diego, who codirects this project with Adnan Mısır, Şanlıurfa Museum, kindly reports:

"As in preceding seasons, the principal objective of the 1994 campaign was to clarify the urban struc. ture of the Middle-Late EBA settlement at Titriş. To this end, the magnetic field gradient survey was expanded to cover the entire Outer Town as well as the previously unsurveyed areas of the Lower Town, resulting already in one of the largest such maps for a Near Eastern site. Ultimately, this survey will pro- duce the first complete map of an EBA Near Eastern city.

"Soundings conducted in various parts of the Outer Town to provide the map with archaeological interpretations already invite a number of preliminary observations. During the latest EB phase, that recorded by remote-sensing, the eastern two-thirds of this district were densely built up without open spaces on a network of fairly straight roadways, known from excavation to have been paved with thick layers of cobbles and sherds. The houses flanking the streets were in some cases large-one building per block - and perhaps suited to extended families. In the central area, larger and more massive structures may represent public buildings. Two intersecting thoroughfares on the map run on a rough north-south line across the western portion of the Outer Town, and for hundreds of meters east-west along its northern edge. In contrast to this densely planned residential area, the northern and western peripheries produced few magnetic anomalies; whether their absence indicates gardens or activity areas, or results from non-archaeological factors, can only be resolved with future soundings. Finally, the outer town was defended by a 6 -m-wide fortification wall on top of a massive glacis, as discovered in trenches just inside the broad moat mapped and tested in earlier seasons. The layout of the Lower Town at the foot of the mound proper appears to share many of these urban features, including the system of streets. The suburbs, on the other hand, may have followed different norms: limited surface survey in an area outside and east of the Outer Town produced significant numbers of blade cores, sug. gesting that at least this suburb functioned as an industrial zone.

"Broad trenches in the Outer and Lower Towns again addressed the critical issue of the site's urban development in the Middle (Kurban IVC-B = EB III) and Late (Kurban IVA = EB III/IV) EB periods, with further investigations into the stratigraphic sequence in these areas. In the eastern sector of the Outer Town, the Middle EB level, built on virgin soil, is characterized by the well-built stone foundations of urban architecture, as yet exposed only in narrow soundings. This level was followed by an apparent hiatus, dur. ing which the area was used as a cemetery with multiple burials in cist graves and jars. During the Late EB reoccupation, when more modest housing followed a different alignment, the location of these graves seems to have been kept in mind when laying out the new constructions. The later houses are now illustrated by several broad exposures (fig. 9). They 


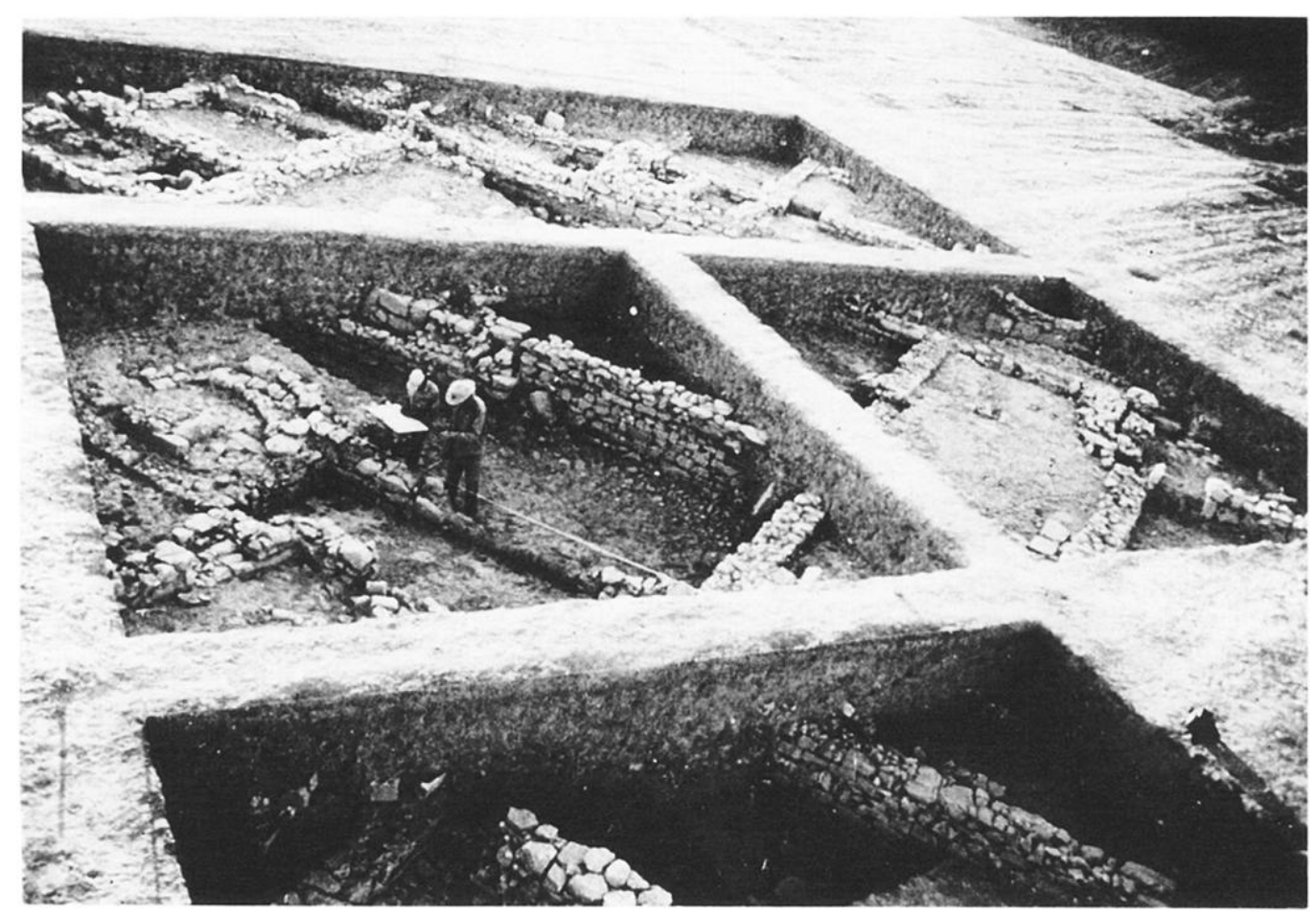

Fig. 9. Titriş Höyük. Late EBA housing in the Outer Town. (Courtesy G. Algaze)

were built as mudbrick superstructures on tall stone foundations, and included several rooms adjoining cobbled courtyards with hearths and ovens. The room of one house contained an oval basin and a drain; tartaric acid residues identify the room as an installation for processing grapes. There appear to be two architectural phases here, both following similar parameters.

"The Lower Town, in contrast, was occupied without interruption, with larger and more impressive buildings that signal a neighborhood of higher status, especially on the western side. Portions of two large buildings with massive limestone foundation blocks were uncovered on either side of a cobbled street. They were built in the Middle EB period, and remained in use with few modifications throughout the lifetime of the city. At a late stage, a stone hypogeum was installed in the southern building below a partitioned room, with access through a semicircular dromos blocked by a limestone door. The tomb contained at least two (poorly preserved) individuals, 42 Late EB vessels including Syrian bottles, and several bronze pins. Well-appointed stone-lined tombs were also characteristic of the Middle EB extramural cemetery $400 \mathrm{~m}$ northwest of Titriş, first investigated in 1981 by $\mathrm{H}$. Hauptmann and again by us in 1994. Although the cemetery has suffered from plowing and other disturbances, it produced good evidence for local mortuary customs: the burials were used for single families, and included violin-shaped marble idols in or outside the burial, and metal jewelry (fig. 10). The tradition of burial in cist tombs is also attested for the pre-urban early thirdmillennium settlement (see AJA 99 [1995] 216 and fig. 7).

"Results of the 1994 campaign support the previous assessment of the urbanization process at Titriş as a swift and well-coordinated project that occurred in the Middle EBA. Subsequent development in the various sectors of the site proved more variable, with the Outer Town undergoing significant transformations while the Lower Town continued largely unchanged. Palaeobotanical and environmental research indicates that the inhabitants practiced a mixed economy relying on grain and legumes, 'cash

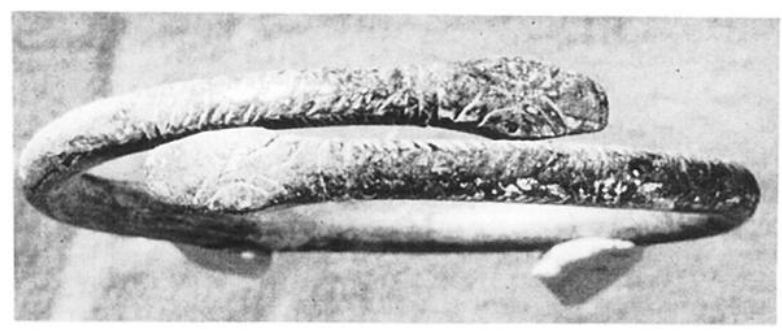

Fig. 10. Titriş Höyük. Silver bracelet from Middle EBA extramural cemetery. (Courtesy G. Algaze) 
crops' such as grapes, and wild nuts and fruits including acorns, in an environment that was moister and more wooded than today. Why this prosperous city contracted to less than a 10 th of its size and retreated to the mound at the close of the third millennium remains a question for future seasons."

The 1992-1993 seasons are reported in KST 15:1 (1994) 153-70 and 16:1 (1995) 107-20; a comprehensive article on the 1994 season appears in Anatolica 21 (1995) 13-64.

Kurban Höyük. Patricia Wattenmaker discusses the organization of domestic craft production in rural southeastern Anatolia with reference to Kurban Höyük's third-millennium phases in G.M. Schwartz and S.E. Falconer eds., Archaeological Views from the Countryside: Village Communities in Early Complex Societies (Washington, D.C. 1994) 109-20.

Kazane Höyük. In their third salvage campaign on the outskirts of Urfa at Kazane, whose extensive lower terrace has been bisected by the GAP irrigation channel, Patricia Wattenmaker and codirector Adnan Misir conducted stratigraphic soundings for the early phases of the site, and opened broader areas to investigate its EB III-MB urban phases.

A sounding for Kazane's earliest-attested period, on the southeastern edge of the outer town, produced Late Halaf levels characterized by pottery with bucranium motifs, stamp seals, and a high percentage of obsidian tools. If these belong to the same Halaf settlement noted from survey elsewhere at the site, its size must be reevaluated at 15-20 ha, rivaling the largest sites known for this culture (and comparable to Domuztepe southeast of Kahramanmaraş: see below). On the west slope of the main mound, a narrow step trench investigated Late Chalcolithic and $\mathrm{EB}$ sequences without reaching the underlying Ubaid. Occupation appears to have evolved here without any interruptions.

Investigations into the EB III Syro-Anatolian urban explosion that transformed Kazane into a 100-ha city, twice the size of contemporary Titriş, were carried out on the terraces east and southwest of the mound. In the eastern lower town, $300 \mathrm{~m}^{2}$ of an EB III monumental building were uncovered: its partial plan has mudbrick rooms with well-plastered floors and interior hearths inside a 5-m-wide wall with stone foundations. This architecture contrasts sharply with an industrial quarter excavated in the southwestern outer town, where flimsy structures were erected on either side of a cobbled street. The city was protected by a fortification system also examined in 1994 on the eastern ridge of the lower town. It consisted of a gravel rampart, $8 \mathrm{~m}$ high and an estimated $40 \mathrm{~m}$ wide, to support a mudbrick cir- cuit wall that was not preserved. These defenses were built during two separate phases, in the mid/later third and late third/early second millennia B.C. The accumulated evidence still confirms that at least parts of the lower town continued to be occupied into the Middle Bronze Age, although the outer town and its industrial quarters had by then been abandoned. For the 1992 season, see KST 15:1 (1994) 177-92.

Oylum Höyük. Under the direction of Engin Özgen, the 1994 season at this major site, near Kilis and the ancient (and modern) crossing into northwestern Syria, focused on the 22-m-high eastern slope and its stratigraphic sounding. Hellenistic, Iron Age, and Middle Bronze buildings were traced, many of them burnt with their contents in situ. Well-preserved mudbrick walling of MB II date promises to become a monumental structure in future seasons. A sounding on the southern slope, where the bronze figurine of a Hittite smiting god was allegedly found in 1993, produced a gold pendant and three architectural levels that bore no visible connections to the figurine. For a photograph of the Hittite figurine, and reports on the 1991 and 1993 seasons, see KST 16:1 (1995) 95-105.

Tilbeşar. A 1994 survey preliminary to full-scale excavations was undertaken by Christine KepinskiLecomte to the southeast of Gaziantep, at the 60-ha site crowned by the Crusader fortress of Turbessel, fief of the kingdom of Edessa. Systematic collection in the northern part of the terrace or lower city produced Halaf and Ubaid pottery, and the full span of later periods through the Middle Ages until the Mongol destruction in A.D. 1263. The Middle Bronze Age is especially well represented. A similar occupational sequence is suggested by the ceramics collected on the 6 -ha mound $(180 \times 320 \mathrm{~m})$ on which the fortress was built. Entrances to the lower city, which overlooks a tributary of the Euphrates to the north, are visible on the southern, eastern, and western sides. For earlier surveys of the site, see H.H. von der Osten, Explorations in Hittite Asia Minor, 1929 (OIC 8, Chicago 1929) 76-77; A. Archi, P.E. Pecorella, and M. Salvini, Gaziantep e la sua regione (Rome 1971); and P. Sanlaville ed., Holocene Settlement in North Syria (BAR-IS 238, Oxford 1985). Continued survey and soundings took place in 1995.

Kahramanmaraş Survey. Elizabeth Carter, Univer. sity of California, Los Angeles, spent a second twomonth season surveying the valleys south of Maraş. She kindly reports:

"The 1994 season increased the survey area to ca. $1,100 \mathrm{~km}^{2}$ and the previous year's inventory by 100 new sites, for a current total of 227 spanning the Palaeolithic to the Medieval periods. The new sites 
are situated for the most part in the drainages of the Aksu and Erkenez Su to the southwest and southeast of Maras. They underscore the general settlement trends that were formulated in 1993.

"Regional cultural patterns were determined by two contrasting features. On the one hand, the rocky outcrops that divide the valley channeled internal communications and encouraged the development of local cultural features, especially noticeable in ceramic traditions independent of those outside this area. Secondly, two communication routes of great interest promoted contacts with the outside, and economic importance to the sites that controlled them: the first on the river branches east and west of Maras, the route into the Anatolian highlands; and the second along the Aksu, leading south and east from Maraş toward Gaziantep and the Euphrates valley. Thus the cultural and settlement patterns in many instances retained a strong local character, while reflecting developments outside the region. For example, a sharp change occurred in the Late Chalcolithic period with the appearance of a largely undecorated and mass-produced ceramic tradition, distinct from that of the contemporary Urukaffiliated sites to the southeast, but sharing the new techniques of manufacture and distribution. At the same time, the number of sites expanded, with many small regional centers connected to specialized sites. A typical center southwest of Maraş, Özen Höyük, is a 6-ha mound with six or more related sites nearby; pottery may have been mass-produced at one, and flints knapped at several others.

"In the Early Bronze Age, settlements again increased in number and spread out over all of the valley's subareas, with at least one major urban center at Danişmend Tepe (perhaps 50 ha), on the route to the east with its comparable settlement history. After a decline from the Middle Bronze through the Iron Ages, perhaps to be explained by a polarizing center at Maraş, the number of sites soared in Hellenistic and Roman times, and tapered off by the Middle Ages. Although Iron Age Maras is inacces. sible because of the modern city, the discovery of an unfinished gate lion in a stone quarry overlooking the Aksu served as a reminder of the region's activities in the Neo-Hittite period.

"A second project of the 1994 survey was systematic collection at the Halaf site of Domuztepe, already recorded during the first season in the southeastern corner of the survey area. The site commands a key pass in the hills along the route linking the eastern and western sections of the central valley, and also lies at the head of an alluvial fan forming some of the richest agricultural land in the region. It is ad- jacent to low hilly country that would have provided excellent grazing lands and a ready source of stone and flint. Exceptional size (18 ha, and 8-10 m high), pottery of "true" eastern Halaf type, and large num. bers of stone bowl fragments and lithics lying on the surface make it an excellent prospect for research into the dynamics of this widespread northern Meso. potamian culture dating ca. 5000 B.C."

Excavations began at Domuztepe (site KM-97) in 1995. For the 1993 survey results, see ArassST 12 (1995) 331-41.

Sirkeli. The third season directed by Barthel Hrouda at this eastern Cilician mound on the present west bank of the Ceyhan combined excavation with magnetic remote sensing, in an effort to assess both the stratigraphic history and the extent of the ancient site. Deep soundings on the eastern and western sides of the mound determined that it was first settled on bedrock during the Chalcolithic period, $5 \mathrm{~m}$ below the present surface. The Chalcolithic occupation was well defined in the western trench, with domestic architecture beside a road. Handmade, chaff-tempered pottery has a red-or yellow-slipped surface with a black core; a few sherds were painted. A cylinder seal of Amuq G-H type, showing a fox standing on a lion, was the only sign of an EB phase, although EB material was found in previous seasons. Middle Bronze architectural levels with typical Cilician Painted ware were uncovered in the central part of the mound. Here, as elsewhere in the soundings, the evidence suggests a gap from the end of the Middle Bronze until the Iron Age, when a large fortified settlement was established and maintained into the Hellenistic period. Houses of this later phase have been excavated both in the central and eastern trenches, and on the northern side where magnetic prospection also located a large structure surrounded by other buildings.

If the Late Bronze Age has so far proved elusive on the mound proper, nonetheless another Hittite royal presence at Sirkeli was discovered in 1994. Once vegetation was cleared from the foot of the cliff where the famous Muwatalli relief overlooks the river and the site, a second, smaller Great King appeared in mirror image $13 \mathrm{~m}$ behind and to the north of Muwatalli's. H. Ehringhaus has published excellent photographs and a short description in AntW 26:2 (1995) 118-19. (For another royal relief at Keben, on the western border of the Muwatalli's "Lower Land," see his article in AntW 26:4 [1995] 215-19.)

Kinet Höyük. A third excavation season under my direction took place in 1994 at this eastern Cilician harbor, generally identified with classical Issos in the northeastern corner of the Mediterra. 


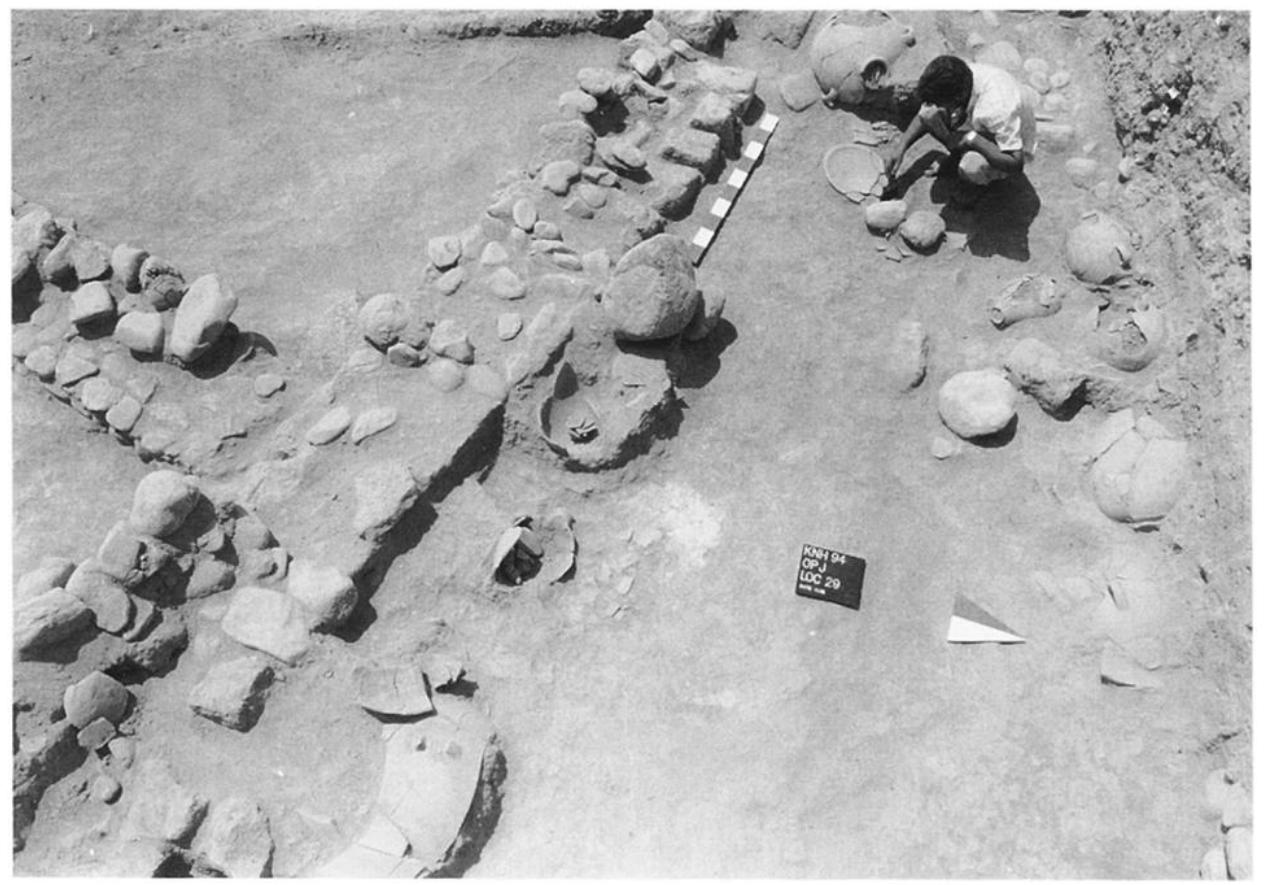

Fig. 11. Kinet Höyük. Late Bronze II storeroom with in situ vessels.

nean. On the west (seaside) slope of the 26-m-high mound, two separate operations began investigating the site's Late and Early Bronze phases. The later trench produced three rooms of a well-planned Late Bronze II (13th century B.C. ) building with a small central court, and a storeroom containing seven Canaanite amphoras and other large jars on or beside their potstands (fig. 11). This level's pottery is identical to the Tarsus and Alalakh repertoire, with the "drab ware" plates and potmarks that characterize the late Hittite Empire. The building was destroyed by hostile forces: bronze arrowheads were strewn about, and a bronze axehead was found embedded in the courtyard wall. For the earlier history of the site, a small trench at the foot of the 1992-1993 step sounding exposed what appears to be casemate wall ing preserved over $2 \mathrm{~m}$ high, and built of alternating fieldstone and brick courses on top of another, similar casemate system. The later version would date to the EB I period, and may mark the western fortified edge of the site. Sherds from the casemates included sixth-millennium Neolithic wares comparable to Mersin's. They suggest an early settlement in the immediate vicinity.

Other operations on the upper west side of the mound expanded the Middle and Late Iron Age architectural sequence to eight building levels spanning the ninth to fourth centuries B.C. A large, violently burnt building (fig. 12) proved to be the source for ash tips containing Neo-Assyrian pottery in a 1993 trench to the northwest. A half-preserved cylinder seal in Middle Assyrian style, representing a god strangling an ostrich (fig. 13), was found on the floor of the western room; although the seal seems to antedate the building by at least two centuries, it would confirm an Assyrian presence at Kinet. The building overlies an equally burnt monumental Middle Iron Age structure that was partially exposed in 1993, and expanded in 1994. An unexpected bonus of the season was the conclusive dating of the glacis and fortification system to ca. 400 B.C., thanks to Attic black-glazed imports and a late basket-handled amphora in the context of a tower and gate.

For the 1992 season, see KST 15:1 (1994) 193-200. S. Steadman presents the Chalcolithic and EB pottery from the regional 1991 survey in AnatSt 44 (1994) 85-103.

\section{Eastern, Northern, and Central Anatolia}

Sos Höyük/Erzurum. As part of the continuing project to document northeastern Anatolia's cultural history, Antonio Sagona and his collaborators at the Erzurum Museum began new excavations at Sos Höyük, a small mound $25 \mathrm{~km}$ east of Erzurum on the route to Pasinler. Soundings carried out at the site in 1987, and cuts made by the overlying modern village, had already suggested that it could fill some of the gaps encountered in the Bayburt region, particularly for the second millennium B.C.

The 1994 excavations uncovered stratified deposits dating to the Medieval, Iron Age, and Early Bronze 


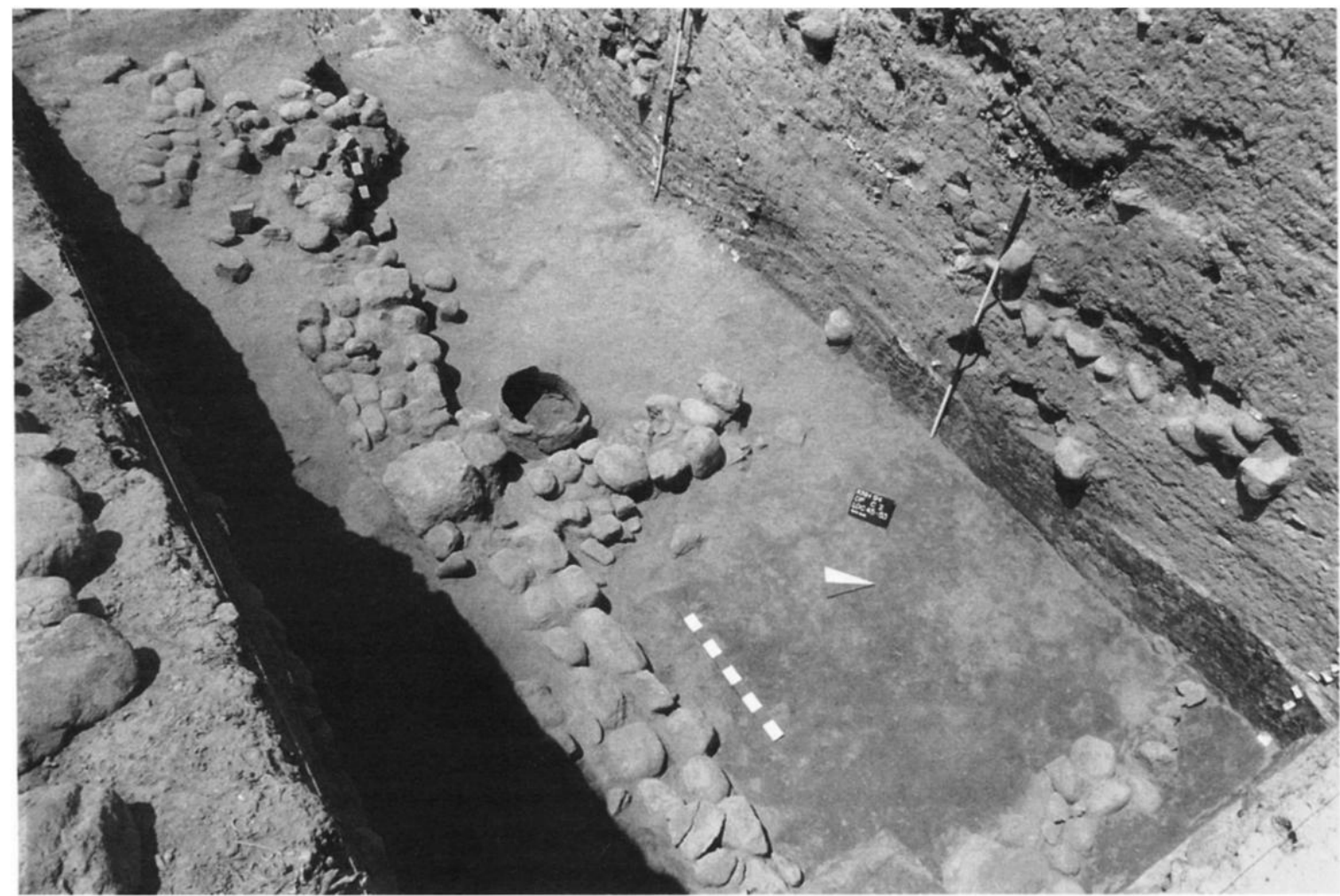

Fig. 12. Kinet Höyük. Middle Iron Age building with Neo-Assyrian pottery.

periods. In an upper operation, three 13th-century A.D. levels of domestic housing were preceded by a large Hellenistic building, the latter destroyed in a violent fire that nonetheless preserved a wooden column capital in situ. Excavations down the mound slope exposed two levels of partial buildings dating to the EB-MB transition at the close of the third millennium B.C. The latest phase of glossy black Early Transcaucasian Karaz ware was well represented by bowls, cups, jars with geometric relief decoration, and trays with elaborate incised fronts unique to the Erzurum region. The lithic industry used obsidian almost exclusively, and includes the tanged projectile points that are the hallmark of the period. Ties with the Caucasus are indicated by a class of graphiteburnished pottery known from the Martkhopi kurgans northeast of Tbilisi; and with the Trialeti cultures by gray wares with stippled bands, and redslipped wares painted with black chevrons.

Survey in the area located cemeteries of pithos burials set in the center of stone circles. They were found to contain either skeletons or tomb gifts, and cannot at present be securely dated.

Büyüktepe Höyük. The 1994 study season and an overview of the 1990-1992 excavations are summarized in KST 16:1 (1995) 161-64.

Bayburt Survey. The final season of a four-year survey in the Bayburt area is published by A. Sagona and P. Brennan in ArassT 12 (1995) 305-16. The report includes a geochemical study of obsidian from the survey and the Büyüktepe excavations.

Sivas Survey. For A. Tuba Ökse's long-term survey project in the Sivas area, see ArasST 11 (1994) 243-58 and 12 (1995) 317-29.

İkiztepe. Önder Bilgi's long-term research at this early Black Sea metallurgical center continued in 1994 with excavations in several areas, including the large sounding at the highest part of the mound. More EB architectural levels of wood structures with elaborate hearths (source of the fires that regularly ravaged the settlement) were uncovered below the

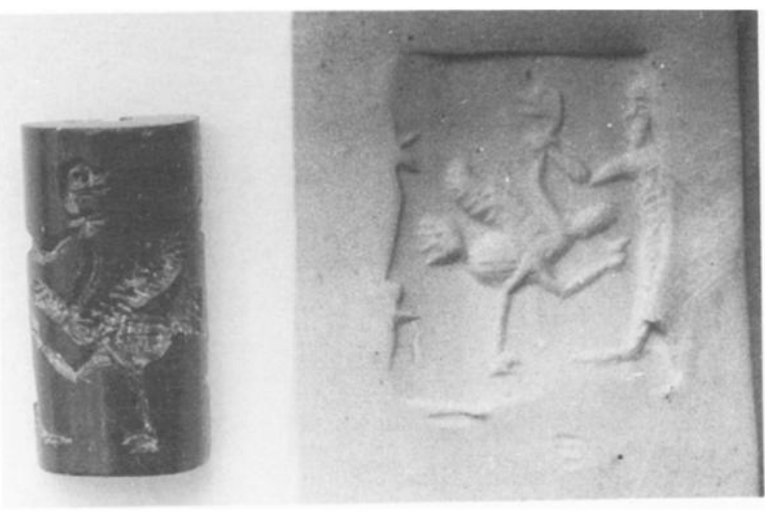

Fig. 13. Kinet Höyük. Middle Iron Age building: cylinder seal and impression. (Photo T. Çakar) 
Iron Age and Hellenistic levels. One such building, thought to be a temple, contained a large number of finds including a crucible and terracotta female figurines. The figurines have large ears with multiple piercings, and look like simplified terracotta versions of the bronze and silver ones known from Alaca and Horoztepe. They are also found at İkiztepe in tombs.

Reports on the 1992 and 1993 seasons are published in KST 15:1 (1994) 235-44 and 16:1 (1995) 141-60; for analysis of metal objects, see ArkST 9 (1994) 77-99. Suggested reconstructions for the typical İkiztepe EB architecture are illustrated in KST 15:2 (1994) 583-96.

Acemhöyük. Further excavation of the service quarters northwest of the Hatipler palace, where Aliye Öztan has been investigating its Middle Bronze stratigraphic history, produced more of the level 3 (Assyrian Colony period) architecture whose mudbrick walls were reinforced near the floor level with a foundation course of juniper timbers. These timbers, numbering 24 by the close of the 1994 season, were recycled from burnt buildings dated to the EBA on dendrochronological grounds by P.I. Kuniholm, and further confirmed by radiocarbon analysis. They span the years 2671 to 2169 B.C. \pm 10 , and have nothing to do with the date of the service buildings themselves (a warning against indiscriminate reliance on scientific dating!).

The service quarters in level 3 were extensive. Their rooms and courts were equipped with ovens, and trash pits with discarded vessels such as the whiteslipped wares with brown-painted decorations known from Kültepe-Karum II. A large court with a circular hearth, and its adjoining room with a platform produced a number of bone handles, pierced shells, and a marble macehead-like tool. A fragmentary obsidian rhyton implies elegant tableware. In the earlier level 4, a structure with an internal platform also contained quantities of bone tools, over 200 knucklebones, and a large inventory of smashed ceramic vessels. Reports for the 1992 and 1993 seasons can be found in KST 15:1 (1994) 245-55 and 16:1 (1995) 189-92; for the ongoing resistivity survey project conducted by M. Drahor, see ArkST 9 (1994) 1-11 and 10 (1995) 229-43.

Kültepe. Despite more than 45 years of research at ancient Kanesh, principal city of Nesha in the MBA, the 1994 season yielded still unfamiliar finds and new data about the activities of 18th-century B.C. Assyrian merchants in the Anatolian highlands. Director Tahsin Özgüç, who has delighted in rediscovering all aspects of these merchants' daily lives, reminds us that these excavations allow a perspective of the period on a human scale, with individuals (not systems) embarking on the long and slow route between Assur and Kanesh, and all for personal gain. There were many such cities in the Old Assyrian commercial world, and Kültepe is merely the Anatolian version, he would argue - but in archaeological terms it must be recognized as exceptional.

The variations in house types that have been revealed by an increasingly large exposure of level II are providing more evidence for social distinctions within the commercial district. In one elegant neighborhood with straight, parallel streets and stone-lined sidewalks, the houses were planned with large reg. ular rooms enclosing flagstone-paved courts. Elsewhere, more modest versions of the standard threeunit house (office with archive, sitting room, court) were appropriate for smaller entrepreneurs. A cramped building with irregular rooms and school tablets shows that insufficient funding for educational establishments is indeed universal.

These architecturally based social hierarchies can be confirmed by the written accounts recorded in the house archives. In 1994, 1,563 more tablets were added to the total of over 17,000 from formal excavations; with them came a harvest of 1,310 seal impressions, some on envelopes not yet opened when the houses were destroyed by fire. One envelope had been stamped with two round seals in the Anatolian tradition beside an Old Babylonian cylinder sealing. Another had been impressed with an Early Dynastic III heirloom, the property of a correspondent with antiquarian tastes. Were these commercial accounts not sufficient to demonstrate the Assyrian community's business flair, then the jewelry that accompanied their burials would give irrefutable proof of their success: a wealth of gold and silver ornaments such as rings and melon-headed pins, and a pin with a lapis head.

Although there have been few contexts from the karum that suggest an interest in formal, structured religion, one room excavated in 1994 may have served a religious function. It was furnished with a hearth or podium and benches along the walls, and con. tained a quantity of miniature white-slipped vessels of assorted shapes decorated with brown paint, a pitcher with four parallel spouts, several pitchers with pinched rims that poured at right angles to the handles, and more of the anthropomorphic "bread. boxes" with yawning mouths. The season also produced an incantation text, the third of this category among the entire tablet inventory. These precautions apparently did not stave off widespread disaster, which the excavator would attribute to local political turmoil.

For a recent publication on the seals, see B. Teissier, 
Sealings and Seals on Texts from Kültepe Karum Level 2 (Uitgaven van het Nederlands Historisch-Archaeologisch Instituut te Istanbul 70, Istanbul 1994).

Karahöyük-Konya. An illustrated summary of the 1992 campaign appears in KST 15:1 (1994) 269-72, together with a plan of trench X's level 1 (Assyrian Colony period) residential and religious district, where Sedat Alp has been excavating during the past several seasons. Two beams from adjacent rooms here have been ring-dated by P.I. Kuniholm to 1784 and 1782 vv B.C. \pm 37 . He has also dated a juniper beam from the earlier level $6 / 7$ to 2181 B.C. \pm 10 .

Kaman-Kalehöyük. Sachihiro Omura's 1994 campaign at the impressive mound that commands the direct route from Ankara to Kayseri, and from Hattusha to the great Salt Lake, brought increased evidence for the site's participation in Hittite and Phrygian affairs. In conjunction with the northern stratigraphic sounding, a broader exposure of the Late Hittite (Kaman III) phase uncovered more buildings with excellent brick architecture, thick plastered walls and floors, and cobbled courtyards, all violently burnt and filled with fallen timbers. In situ finds in. cluded superbly burnished Hittite pottery, relief ceramics, bronze vessels and weapons, stamp sealimpressed jar stoppers, 20 Hittite hieroglyphic Old Kingdom sealings and one stone seal with hieroglyphs, a crystal stamp seal representing an eagle, and a faience scarab. This city was protected by a circular fortification constructed in standard Hittite casemate fashion. It did not withstand the assault that brought this phase to an end, however, trapping 21 residents (so far!) whose skeletons were found among the ruins.

Concurrent excavations of the Early Iron Age levels (Kaman II), again on the northern side, uncovered several rooms of what may be an Early Phrygian official building constructed of wood on stone foundations. Underlying this ninth-century B.C. architectural phase are the handmade black-burnished ware and pit houses that characterize the arrival of the Phrygians at Kaman, Gordion, and elsewhere: sunken floors reinforced in the corners with stones, and walls marked by postholes.

Preliminary reports for the 1992 and 1993 seasons are published in KST 15:1 (1994) 273-92 and 16:1 (1995) 313-30, and S. Omura ed., Kaman-Kalehöyük 4 (Japan: Middle Eastern Cultural Center 1995). For the annual regional surveys that are placing the site in its cultural and environmental setting, see AraşST 11 (1994) 311-36 and 12 (1995) 215-44.

Boğazköy. With the 1994 season, Jürgen Seeher assumed the direction of excavations at the Hittite capital, and continued the previous year's program of investigations in the northeastern corner of the city at Büyükkaya, the largest of Hattusha's citadels. By the close of the season, almost all of the Hittite fortification circuit had been uncovered. It was built in the standard casemate fashion with regular projecting towers, and on the north, a monumental gate (again the city's largest) facing Yazılıkaya. Inside the citadel, soundings were first made in the area of a large rectangular building noted, along with two others, in a resistivity survey. Finds consisted of several imperial seals and sealings, a hammer-seal of Kültepe Karum type, tablets, and many miniature vessels just inside the northern gate. When Büyükkaya was remodeled during the Phrygian period, a system of water channels was installed in connection with the gate and a roadway leading up to a district of small workshops. The earliest Iron Age settlement at Boğazköy seems to have been located here, as had already been suggested by excavations in the 1950s. The pottery, all of it handmade, includes a painted ware that could be considered a prototype for the Phrygian animal style with deer (see I. Bayburtluoğlu in $A A$ 1994, 324-25).

A new computer-generated topographic plan of the entire site is underway - a project estimated to take two years - in order to produce a more detailed map of Boğazköy's irregular and challenging terrain. Reports on the 1992 and 1993 seasons appear in KST 15:1 (1994) 293-308 and 16:1 (1995) 199-217; for 1994, see $A A 1995$ (forthcoming). Seeher has published a retrospective of his predecessor Peter Neve's directorship in BiblArch 58:2 (1995) 63-67. The inscribed bronze sword discovered outside the Lion Gate is placed in a typological context by A. Müller-Karpe, "Anatolische Bronzeschwerter und Südosteuropa," Festschrift für Otto-Herman Frey zum 65. Geburtstag (Marburger Studien zur Vor- und Frühgeschichte 16, 1994) 431-44; see also O. Hansen, "A Mycenaean Sword from Boğazköy-Hattusa found in 1991," BSA 89 (1994) 213-15; M. Salvini and L. Vanetti, "Una spada di tipo egeo da Boğazköy," PP 276 (1994) 215-36; and H.G. Buchholz, "Eine hethitische Schwertweihung," Journal of Prehistoric Religion 8 (1994) 21-41.

Alaca Hüyük. P. Neve reconsiders the chronolog. ical setting of the Sphinx Gate in N. Cholidis et al. eds., Beschreiben und Deuten in der Archäologie des Alten Orients: Festschrift für Ruth Mayer-Opificius (Münster 1994) 213-26. For textual analogies relating to the reliefs, see A. Ünal in AnatSt 44 (1994) 207-18.

Ortaköy-Çorum. Excavations conducted by Aygül Süel in 1994 at this 8.5-ha imperial Hittite center, $50 \mathrm{~km}$ northeast of Boğazköy, uncovered more of the monumental complex now called Building A, and extended to the upper citadel and a neighbor- 
ing field. The northern part of Building A functioned as a kitchen and service wing. Along the building's west side, which was followed for $55 \mathrm{~m}$, a sequence of corridors and cobbled courts filled with brick col. lapse from an upper story produced 250 tablets and one bulla. The violent fire that burned the building, and bronze weapons - a dagger and spearheads found within the debris all speak of catastrophic hostilities. Wood samples without bark now give a dendrochronological terminus ante quem of 1304 vv B.C. \pm 37 for the building's construction. Research on the (now forested) upper citadel, which was separated from Building $A$ by a series of terraces, succeeded in tracing parts of its Hittite fortification sys. tem as well as a cobbled road. In contrast, soundings in the outlying field produced rubble walls of a later period, perhaps connected to the Roman cemetery that overlies the Hittite site.

Further study of the more than 2,000 tablets recovered here confirm that it was part of a Hurrian geographical and cultural region, with the Hurrian language used for most of the archival records and omen texts. They also suggest that Ortaköy can now be identified as ancient Sapinuwa.

Alişar-Konaksu valley. Imminent flooding of the Konaksu valley because of dam construction led Ronald L. Gorny and his 1994 team to intensify their regional survey of the Alişar area, both on the ground and from the air with balloon photography. Soundings were conducted $20 \mathrm{~km}$ northwest of Alişar within the flood zone at the large site of Çadır Höyük, which like its more famous neighbor was occupied from the Chalcolithic to the Late Roman periods. Notable findings include EB I obsidian debitage and tools, violently burnt walling that could represent an Iron Age or Hellenistic fortification system, and a Roman structure on the top. The site appears to have expanded significantly toward the south in the Hellenistic period. For a summary of the project, see BiblArch 58:1 (1995) 52-54. The 1994 season's preliminary report appears in Anatolica 21 (1995) 65-100.

Gâvurkalesi. In 1994, Steven Lumsden, Bilkent University/Copenhagen-Carsten Niebuhr Institute, continued his intensive survey of the hill dominated by the Hittite reliefs and masonry that were first studied by von der Osten in 1930. He kindly reports:

"The second season's primary goal was to plan all visible surface architecture, a project that was facilitated by the year's exceptionally dry climate and lack of vegetation. In addition to the architectural features recorded by von der Osten - the Cyclopean structure, the summit's enclosure walls, and the towers and walls directly below the reliefs - it was also discovered that walls could be traced all the way to the base of the hill's eastern, southern, and western slopes (fig. 14). The site was therefore much bigger and more complex than previously noted.

"The Hittite contributions to the site should now be reevaluated in several key aspects. The basalt Cyclopean structure behind and north of the reliefs on the outcrop's summit extended west beyond von der Osten's plan and down the slope, to enclose a much larger platform or terrace than in the 1930 version. Scattered basalt architectural elements such as a column or statue base and a possible lintel block suggest that the platform supported a monumental building of the Hittite period instead of functioning only as a retaining structure for the corbeled chamber. Local reports of postern gates at the site would indicate further constructions around the hill. On the other hand, the tower and ceremonial ramp that von der Osten identified as a monumental approach, on the southern and southeastern slope below the reliefs, may well need to be redated to the Phrygian period: their assembly, and the use of limestone blocks, match the stonework of the Iron Age fortification enclosure that crowns the summit.

"The Middle and Late Phrygian reoccupation at Gâvurkalesi, previously judged to have been a small hillfort, can also be extended well beyond the sum. mit thanks to the coherent system of radiating terrace walls that were planned along the slopes in 1994. The Phrygian site would thus have measured approximately $1,000 \mathrm{~m}$ east-west and $600 \mathrm{~m}$ north-south to cover both the valley floor, its sloping borders, and the high hill proper. Access to the citadel in its northeastern corner, as suggested by von der Osten, can now be substantiated by massive walling appropriate for a defensive tower or fortified gate. There may also have been another entrance on the north. west, via a ramp leading up to a smaller gate. The Phrygian settlement, like its Hittite predecessor, has become far more sophisticated and monumental than could have been anticipated before the start of this survey."

For the 1993 season, see AraşST 12 (1995) 267-80.

Kını-Kastamonu. A hoard of over 30 Hittite metal vessels, among them three bull rhyta and a bowl with figural reliefs and a hieroglyphic inscription, was brought to the Kastamonu Museum in 1990, after being unearthed in a gravel quarry to the north of Kastamonu on a direct route to the Black Sea. In 1994, Aykut Çınaroğlu began a survey and excavation project at the site, now named Kınık after its nearest village. Despite bulldozing and large-scale earth removal, the season produced more metalwork as well as stratified deposits.

Initial surface collection on the site's steep slope 


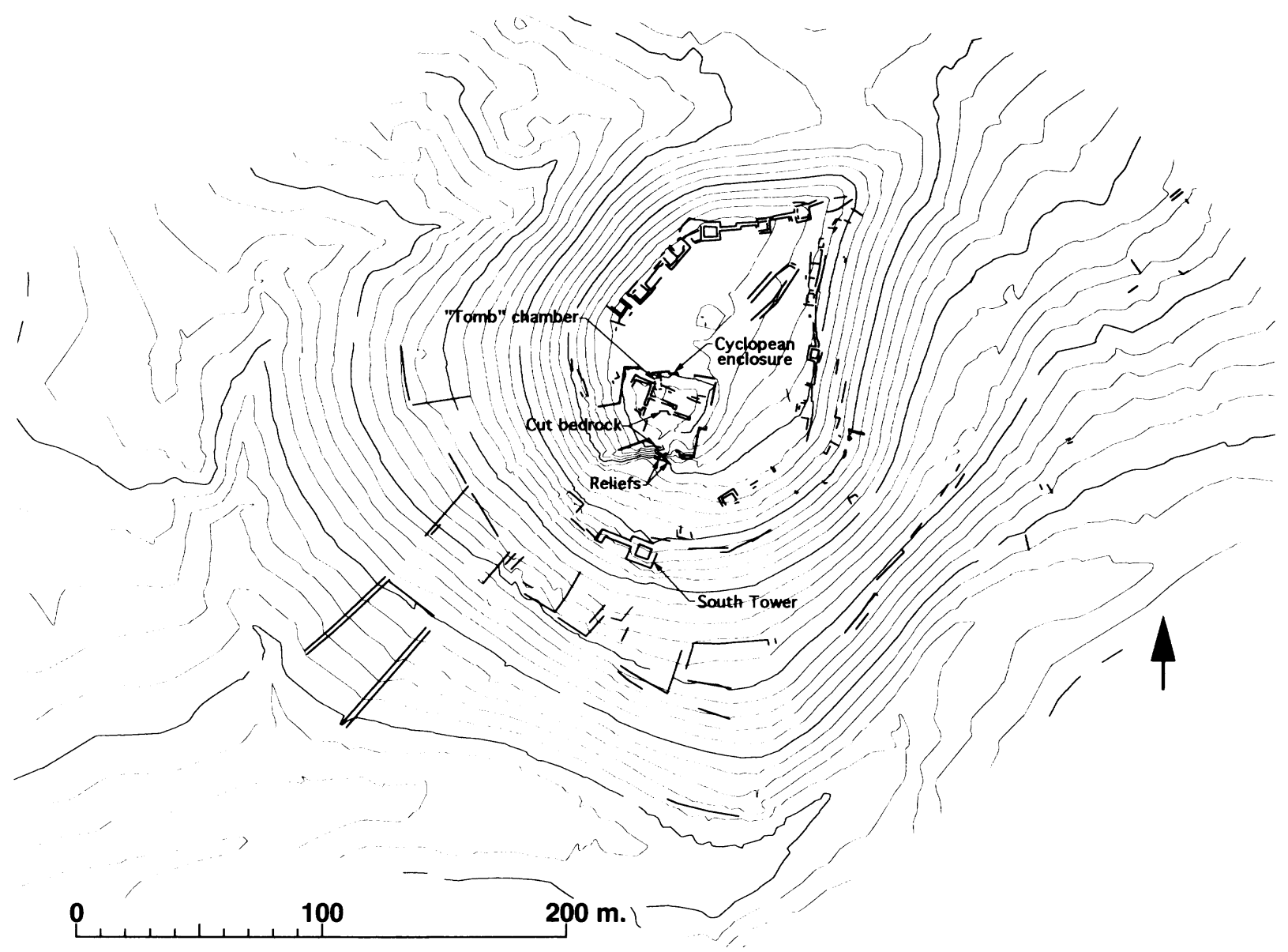

Fig. 14. Gâvurkalesi. Plan. Contour interval 2 m. (Courtesy S. Lumsden)

netted several hundred more examples of the vessels in the Kastamonu group: plain and fluted tankards and omphalos bowls, and the ears and horns of at least three new rhyta. A sounding down to bedrock at the slope's lower end uncovered three architectural levels associated with stone tools, metal scraps, and very burnt pottery, perhaps the remains of workshops. Higher up the slope, excavations cleared a well to a depth of $6.5 \mathrm{~m}$ without reaching its bottom. The well was marked at the top by a pair of bull's horns, and deliberately blocked with alternating layers of sand and aragonite. This area otherwise consisted only of erosion layers filled with bronze objects, and some items in precious materials: an electrum spearpoint, gold handle revetments, a gold spacer bead, a miniature lead ladle, a rock-crystal vessel in the shape of a conch, a bronze figurine of a warrior with helmet, spear and round shield, and a gold shield and electrum spear for a second fig. urine. The warrior figurine is not in a familiar style, in contrast to the Kastamonu relief bowl, where three characteristically Hittite hunters engage in a lively contest with deer, bulls, lions, and a boar.

The inscription on the Kastamonu bowl refers to a dedication by a palace official named Taprammi, who was already known from the Boğazköy and Ras Shamra archives, and more recently from the cache of bullae discovered at Nişantepe (D. Hawkins in Festschrift Nimet Özgüç [Ankara 1993] 715-17). Future campaigns may explain his association with Kınık, and indeed the very nature of this surprising site, should anything remain of the vessels' source at the top of the hill. For the Kastamonu collection, see K. Emre and A. Çınaroğlu, "A Group of Metal Hittite Vessels from Kınık-Kastamonu," Festschrift Nimet Özgü̧ 675-713; and A. Çınaroğlu in Müze 4 (1990-1991) 53-59. H.G. Güterbock and T. Kendall discuss a silver fist closely related to this hoard in Festschrift Vermeule 45-60.

Kussakl. The second, 1994 season at the 18.ha Hittite center located on a high plateau, $60 \mathrm{~km}$ south of Sivas near the village of Başören, again attested to the success of remote sensing in directing the research targets of Andreas Müller-Karpe and his team. Geoelectrical/resistivity maps have now produced clear plans of a city gate to the north, the casemate fortification wall with regularly spaced towers enclosing the site, and more large structures to the west 
of and parallel to the North Terrace temple excavated in 1993. Excavations in three separate areas proved equally remarkable. Continued work on the 54-room North Terrace temple showed that the building had seen occasional repairs. Behind its twin cellas, now known to include the typical Boğazköy temple niches in their back walls, a small room contained 61 bullae impressed with Early-Middle Hittite-style seals belonging to, among others, a Šuppiluliuma and a Samili. Of particular interest is a hieroglyphic sealing naming a local king Ma/mi-ZíTi-ma (fig. 15). The building seems otherwise to have been stripped of all contents before it was burnt, although one room produced a cache of 12 superb wing-tipped arrowheads. Investigations outside the temple, against its southeastern wall, revealed an annex with two rectangular stone-lined baths supplied (or drained) by a water channel made of fitted terracotta pipes. A stratigraphic probe against the temple's western corner indicates that it was built above an Old Hittite level of secular structures that included a workshop. After the temple was abandoned, a third phase of rubble walls was constructed over the immediate area, although not over the temple itself.

On the western side of the acropolis, which dominates the central and eastern part of the city, excavations exposed more of the residential district that was continuously occupied from the Old Kingdom through the Hittite Empire, and-like the templeviolently burnt. A new trench on the top of the acropolis uncovered the archive of another large Hittite building $(24 \times 35 \mathrm{~m})$, unfortunately damaged by an Iron Age reoccupation. The archive has so far yielded 43 tablets, among them six texts that discuss the festivals of a city named Sarissa, and the comings and goings of its king. Kuşaklı can therefore be identified with this well-known Hittite cult center, whose patron weather god is invoked in the Qadesh treaty between Hattusili III and Ramses II.

For a brief 1994 season report, see Orient-Express 1995:1, 3-4; a preliminary report on the survey and first two seasons (1992-1994) appears in MDOG 127 (1995) 5-36, with an epigraphical report by G. Wilhelm.

Porsuk. Excavations at the Hittite citadel that controlled the valley between Ulukışla and the Cilician Gates, the main pass from the plateau down to Kizzuwatna and the sea, were reactivated in 1994 under the direction of Olivier Pelon. Work continued on the site's massive fortification system, of which a sloping 3-m-wide corridor has now been followed for a length of $31 \mathrm{~m}$, where it opened onto a large cobbled courtyard. Quantities of burnt wood beams were strewn in the corridor debris, attesting to a

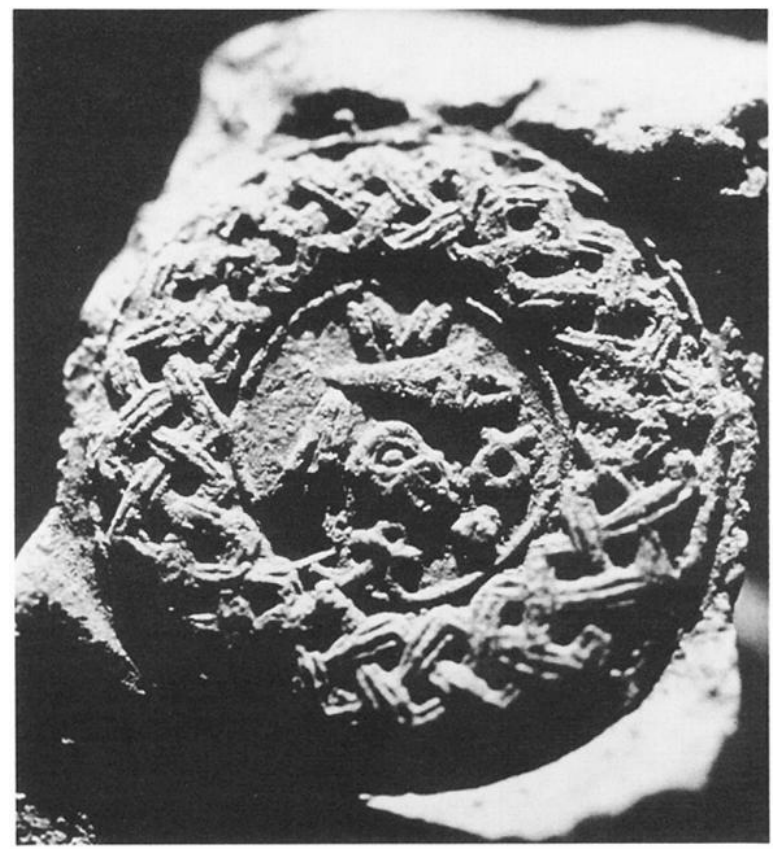

Fig. 15. Kuşaklı. Sealing with hieroglyphic royal name. (Courtesy A. Müller-Karpe)

violent destruction dated by red-burnished wares and a hammer seal to the end of the Hittite Empire. Like so many other Hittite fortified hill sites, Porsuk was reoccupied, after a hiatus, in the Early Iron Age. The new settlement established itself within the walled enclosure, and apparently specialized in ironworking. A faience figurine of an Egyptian seated goddess from this period indicates that the site maintained its importance as a link with the coast.

Investigations were also pursued on the top of the mound, where a third-century A.D. cemetery overlies a Roman town of the first-second centuries A.D. The occasional cross among the burials signals the presence of an early Christian community. A report by C. Abadie-Reynal on the 1992 cemetery excavations appears in KST 15:2 (1994) 211-23.

Kilise Tepe. A second route between the Hittite heartland and the Mediterranean followed the dramatic Göksu valley, which links the Konya plain with western Cilicia - the "Lower Lands" that were con. trolled in the 13th century B.C. by the elusive capital Tarhuntašša. Surveys by J. Mellaart (Belleten 22 [1958] 311-45), D. French (AnatSt 15 [1965] 177-201), and, more recently, the Silifke Museum located Roman and especially Byzantine sites in the valley, and a concentration of prehistoric ones in the region of Mut (Roman Claudiopolis). The construction of a major dam on the lower Göksu will, when completed, flood a number of these, including Chingene Tepe, Maltepe, and Kilise Tepe (misnamed Maltepe in the 
surveys) on opposite banks of the river ca. $25 \mathrm{~km}$ south of Mut. In 1994, salvage excavations began at Kilise Tepe under the direction of J. Nicholas Postgate, Cambridge University, who kindly offered the following report:

"Kilise Tepe sits on a high promontory of natural conglomerate to the east of and overlooking the Göksu River, near a crossing point confirmed by the presence of a second prehistoric mound (the true Maltepe) on the other side of the valley. A good spring at the mound's northern end and other springs in the immediate region ensured that the area was suitable for settlement and agriculture in antiquity, as indeed today. Pottery collected systematically from the surface of the $100 \times 100 \mathrm{~m}$ site ranges from Chalcolithic to Early Iron Age types, including Hittite burnished wares. The site was also occupied in the Hellenistic and Byzantine periods, with Byzantine material and 'Alahan monastic ware' on the north side suggesting the location of the church that gave the mound its name.

"Two large step trenches were opened on the mound's eastern and northwestern sides. The eastern trench exposed, for a length of $25 \mathrm{~m}$, a massive stone wall running north-south along the edge of the slope to form a high, fortified enclosure on top of the Bronze Age mound. An Early Iron Age date is suggested by architectural levels inside, or west, of the fortification wall, which pitting suggests had gone out of use by classical times. The deep northwest trench produced a stratified sequence of secondmillennium B.C. occupations capped by Iron Age clay-lined pits for grain storage, and finally Byzantine walling. Its Bronze Age levels were all destroyed in violent fires, and consequently contained excellent floor deposits. For the two LB architectural levels, close ties with the Hittite Empire are indicated by fine red-and buff-burnished wares, lentoid flasks, libation arms, and a stone seal of bulla type with the name of the official Satuwali. They were preceded by two Middle Bronze phases: the later with walling, a courtyard, floors with pottery typical of the Anatolian plateau, stamped terracotta crescents, and a hearth containing at least five burnt cervid horn cores; and the earlier a mudbrick building with interior benches and vessels datable to the EB/MB transition. Although it is at present difficult to speculate on Kilise Tepe's political status during the Middle Bronze and Iron Ages, one can already conclude from the 1994 excavations that during the later second millennium, the site functioned as an administrative center and no doubt military garrison of the Hittite kings."

For a recent article discussing the Hittite relief carved on the cliff face at Keben, in the lower Göksu valley and $25 \mathrm{~km}$ inland from Silifke, see H. Ehringhaus, AntW 26:4 (1995) 215-19.

\section{Western and Coastal Anatolia}

Kanlıgeçit. Mehmet Özdoğan and Hermann Parzinger expanded their Thracian project in the Kırklareli region to Kanlıgeçit, where a few sound ings were carried out in 1994. Although the site has suffered from plowing, and road and railway construction, it nonetheless preserves key stratified ma. terial. Troy IV pottery was recovered here, the first attestation in the region for an EB III connection between the Balkan cultures and the Troad. Just below this level, a deposit of pre-Cucuteni and Karanovo V Balkan material again underscored the fourth-millennium gap observed so far throughout these sites; but it also brings the onset of this interruption down by a few centuries.

Haclartepe. Excavations in the periphery of Ilıpınar (see above, under "Later Neolithic: Ilıpınar") were carried out here for a second year by J.J. Roodenberg in an effort to find the settlements that used Ilıpınar as a cemetery during the Chalcolithic and EB periods. The Hacilartepe soundings again uncovered modest wattle-and-daub/half-timber housing, a revival of the local Neolithic tradition. Abundant black-burnished pottery is in the EB style of the Troad and Demircihüyük, but moldmade in local clay rather than coiled. Since the connection between this settlement and the Ilıpınar EB cemetery $300 \mathrm{~m}$ distant is now secure, there is good hope for a Chalcolithic predecessor in reserve for a future season. For the first (1992) campaign, see KST 15:1 (1994) 171. The pottery is analyzed by A. van As et al., in Newsletter of the Department of Pottery Technology (Leiden Univer. sity) 11-12 (1993-1994) 54-73.

Demircihüyük. The small finds from the 1975-1978 excavations are published by A. BaykalSeeher and J. Obladen-Kauder in M. Korfmann ed., Demircihüyük IV: Die Kleinfunde (Mainz 1995).

Troy. The seventh season of the new Troia project maintained its momentum with an average team of 70 working for over two months in an area of 1,905 $\mathrm{m}^{2}$. One major focus of the 1994 campaign concerned the Bronze Age site's urban development, as kindly reported here by director Manfred Korfmann, Tübingen University:

"The postulate that Troy's fortification enclosure expanded steadily from period to period throughout the Bronze Age was reexamined in 1994, and can now be confidently refuted. It has become clear that the first major fortification systems of mid-late Troy I and II (2700/2600-2450/2400 B.C.), which were 
significantly rebuilt and restored at least eight times, served as the basis for the walls of Troy III, indeed an observation already made by Schliemann and Dörpfeld. The short-lived Troy III citadel thus merely added modifications to its immediate predecessor. In contrast, the enclosures of Troy IV and V must have been located well beyond the perimeter of Troy VI's fortress, which overlies domestic architecture wherever soundings have been opened. The Troy IV period (close of the third millennium) appears to have suffered from considerable unrest: it includes six burnt phases, and the faunal remains suggest an exceptional reliance on hunting, and perhaps an impoverished economy. House types followed the 'Anatolian settlement system' noted at Demircihüyük, with long two-room structures sharing party walls, and each containing a domed oven immediately inside the entranceway. Remains from Troy $V$ cap these in all areas, and therefore would have matched the expanded plan established in IV. With Troy VI (17001250 B.C.) and the establishment of a 2-ha lower town extending $400 \mathrm{~m}$ south of the mound's South Gate, the fortifications around the citadel were built and replanned at least three, and more probably four, times. Structures in the lower town and on the citadel show a complete disregard for preexisting remains (whether burials or architecture), perhaps because their builders were newcomers to the site. The succeeding Troy VII, whose minimum of four phases span the close of the Late Bronze and the beginning of the Iron Age (1250-1040/1000 B.C.), marks a dramatic contraction in the city's fortunes. Therefore, the 'Onion Model' for the development of Troy can now be discarded in favor of more diachronic fluctuations in its urban configuration.

"The 1994 program of restoration consolidated more of the Troy VI citadel walls and Hellenistic additions west of the South Gate, and began work in the area of the Northwest Bastion. A new walkway was built above the Troy II ramp, to divert traffic away from the ancient access to the citadel. Hope for the long-term protection of the site and its setting, however, rests with the creation at Troy of a national park, for which we continue to make every possible effort."

Interim reports on the 1993 season have appeared in Studia Troica 4 (1994) 1-50 and KST 16:1 (1995) 239-62; for 1994 in Studia Troica 5 (forthcoming). Frank Calvert's pioneering work at Hisarlık is championed by M. Robinson in AnatSt 44 (1994) 153-68; and by S.H. Allen in AJA 99 (1995) 379-407 and Archaeology 48:3 (1995) 50-57.

The Troy treasure in the Pushkin Museum is discussed in my introductory commentary. For Kum Tepe, see above, under "Later Neolithic"; the post-
Bronze Age excavations at Troy are presented below under "Classical, Hellenistic, and Roman: Troad."

Miletos. A research program on Bronze Age Miletos, with new excavations as well as study and publication of the finds from earlier excavations, began in 1994. Its main goal is to characterize Minoan and Mycenaean influence and/or presence in Bronze Age coastal Ionia. Wolf-Dietrich Niemeier, Heidelberg University, generously reports on his first campaign:

"At the start of the six weeks' season, excavation began on the Stadium Hill, where P. Hommel claimed to have uncovered a Mycenaean megaron in the early 1970s. Hommel's trench was cleaned, and new trenches were opened to its south. In the walls of the supposed Mycenaean megaron we identified reused Archaic building material together with sherds of Archaic pottery. Thus the building must be redated, probably after the Persian destruction of 494 B.C. In the southern trenches, we first came down on the ruins of the village of Eski Balat, then on settlement debris of the third-fourth centuries A.D. overlying bedrock. Stadium Hill, therefore, was not occupied at any point during the Bronze Age.

"Investigations were then shifted to the area of the Athena Temple, where Bronze Age remains had been revealed during campaigns early in this century, and again in 1938 and the 1950s-1960s. We opened a series of trenches underneath and south of the east-west Roman road south of the sanctuary. In two trenches, remnants of the Roman road were sitting directly on the stone foundations of a Late Geometric/Early Archaic house; it is hoped that a stratigraphic sequence of Dark Age and Late Bronze levels will be recovered below this house in a future season. In most of the other trenches, fill from the earlier excavations accounted for over $2 \mathrm{~m}$ of deposit. At the bottom of three, however, we finally reached an undisturbed Bronze Age destruction level with masses of burnt mudbrick debris, charcoal, and great quantities of local Minoan domestic pottery such as conical cups, tripod cooking pots, and bridgespouted jars (fig. 16). Fine decorated pottery imported from Crete dates this destruction to the transition from LM IB to LM II (ca. 1500 B.C.). The deposits also contained fragments of elegant wall paintings (fig. 17). The water table encountered at this level prevented us from proceeding further. With a pump installation next year, we hope to excavate this phase more extensively, and especially to recover architectural remains."

The post-Bronze Age excavations at Miletos are presented below under "Classical, Hellenistic, and Roman: Ionia." 


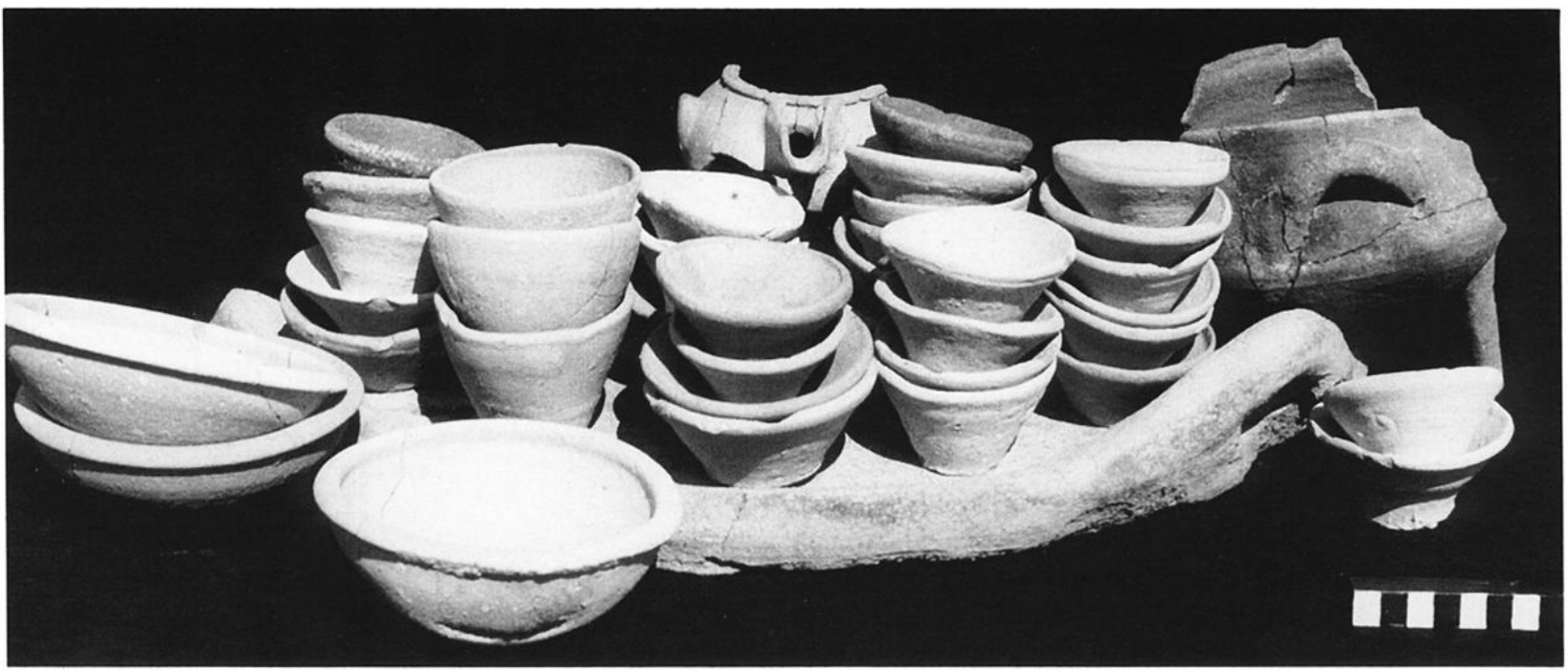

Fig. 16. Miletos. Local Minoan domestic pottery. (Photo W.D. Niemeier)

Liman Tepe. Geomorphological research in the Liman Tepe area has now defined the Bronze Age topographical setting that ensured the site's attraction as a harbor: it was originally on a promontory flanked by two deep bays, which erosion gradually filled to form the present shallow inlet. Aerial photographs also revealed an enclosure extending under water beyond and parallel to the EB bastion, an indication that the settlement was much larger than its current situation would indicate.

This information adds a further dimension to the

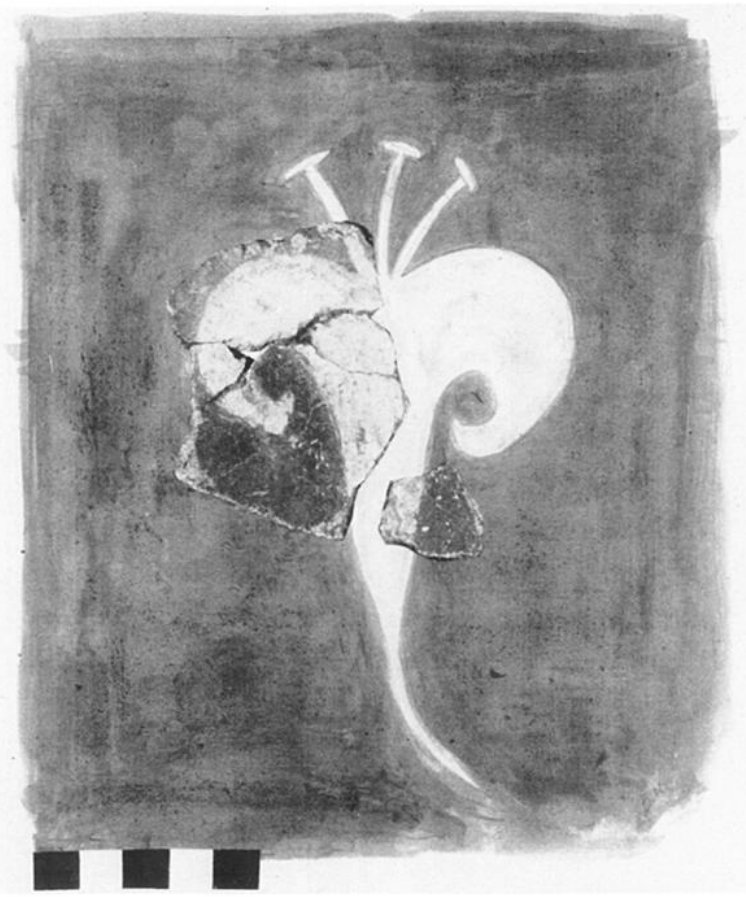

Fig. 17. Miletos. Minoan fresco fragments: white lily on red ground. (Reconstruction B. Niemeier) results of Hayat Erkanal's continued archaeological findings in the previous seasons' trenches, where the 1994 campaign focused on the Middle and Early Bronze occupations. The three parallel apsidal buildings excavated in 1993 as level 4, now to be dated early in the MB period, were supplemented by another two identical structures again oriented paral. lel and east-west; they suggest the presence of many more aligned in organized rows. Matt-painted ware of Lerna $V$ type, although not from a secure context, nonetheless indicates contacts beyond the Aegean. The underlying EB-MB transitional level 5, exposed for the first time in 1994, in contrast bore no sign of neat planning. Its houses were irregularly laid out, with cobbled floors, ovens, and surrounding pits. Finds include a charming terracotta bear. Elsewhere, broad exposure of an EB III level has revealed the massive rubble walls of large structures perhaps comparable to the Argolid "corridor house" plan, one of them approaching palatial scale. Pottery re covered in large quantities from a storeroom includes one Troy II red-burnished vessel and sauceboats. Chalcolithic pottery was also recovered in excavations near the EB fortification wall at the southern perimeter of the site, perhaps in conjunction with an earlier defensive system across the inland side of the promontory.

Preliminary reports appear in KST 15:1 (1994) 361-73 and 16:1 (1995) 263-79. The Urla municipality has also produced an attractive bilingual EnglishTurkish brochure about the excavations.

Panaztepe. The 1994 excavations were carried out by Armağan Erkanal in three separate areas at the eastern base of the acropolis, to investigate the sequence and nature of settlements for the cemeteries 
on which previous campaigns concentrated. Two of the trenches confirmed that the Bronze Age site was reoccupied only in the Byzantine and Ottoman periods, when the region revived its former economic prosperity. The third trench exposed an LB/LH IIIA-B ashlar building with several regularly planned rooms. Finds included Mycenaean pottery, a gray Minyan fenestrated fruitstand, and a stone mold. Just outside it was buried a 35-year-old woman, laid out on her back and accompanied by modest gifts (terracotta beads or spindle whorls). Skeletal analysis indicates that she died from violently inflicted wounds. The fourth period represented at Panaztepe, a long Middle Bronze Age sequence, produced an intriguing structure, perhaps a cult room: one of its walls was interrupted by a niche faced with an upright slab or orthostat, in association with an overturned cup and a burnt vessel filled with animal bones. Pottery suggests an EB-MB transitional date for this phase, as well as antecedents for the gray ware that later developed into the full-blown LB type. The excavator proposes that this site may provide a key to the chronological and geographical distribution of Minyan ware. For brief reports on the 1992 and 1993 seasons, see KST 15:1 (1994) 461-66 and 16:1 (1995) 281-85.

Ephesos. A Mycenaean level in the Artemision sounding is reported below under "Classical, Hellenistic, and Roman: Ionia."

Kaş-Uluburun. The 1994 season at the LB shipwreck off the coast of Kas brought to completion, after 11 years, the longest and deepest excavation project yet to be undertaken by the Institute of Nautical Archaeology. Cemal Pulak kindly offers the following commentary on his concluding campaign:

"Recovery and mapping projects, requiring a season of nearly three months, completed our underwater investigations of the Late Bronze merchant vessel that ran aground against the rocky Uluburun promontory toward the close of the 14th century B.C. The first involved excavating the last remaining cargo in the central part of the site, where an exceptionally deep deposit had collected in a gully sealed by the lowest layer of copper ingots (raised in 1993) and elements of the ship's hull. The finds ran the entire spectrum recovered from elsewhere on the wreck. Organic materials sieved from the sand matrix included pomegranate, fig, grape, and olive; herbs and spices (coriander and sumac); pulses and wild grasses; and nuts, such as almond and pine. Beads in a rich variety of materials, shapes, and sizes (fig. 18: faience [ribbed], agate, ostrich eggshell, quartz, steatite, amber, and chalcedony) increased the previous collection by the thousands. Other goods included

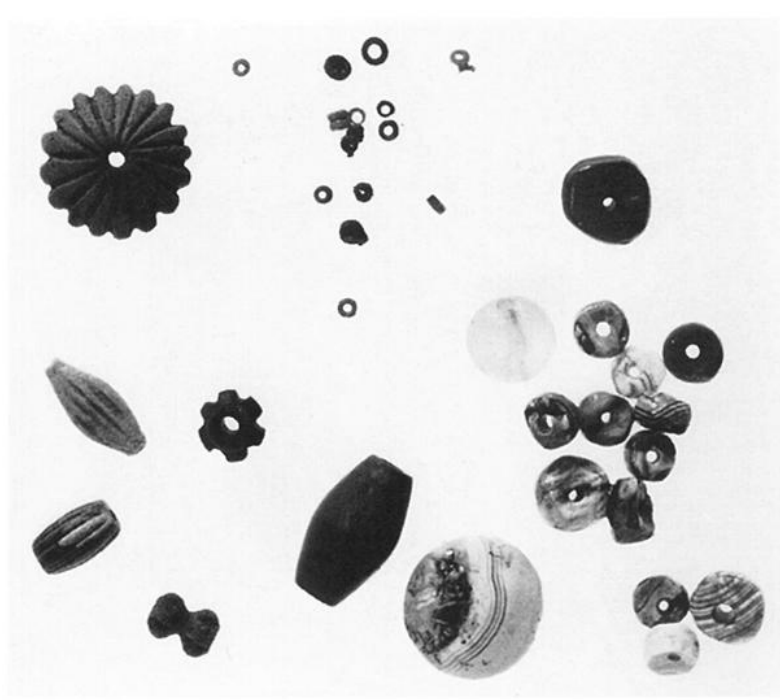

Fig. 18. Uluburun. Beads. (Photo L. Ray Martin)

Red Sea shell rings inlaid with red glass; ivory scepters and their pomegranate-shaped finials (fig. 19); crescent pendants in what seems to be a tin-lead alloy; bronze Bes pendants; an amethyst scarab blank and a second possible example in a black stone; and, as raw materials, a complete ostrich egg, sections of elephant tusks, hippopotamus tusks and canines, and more glass ingots. Cypriot export ceramics were found spilled out in the fill as well as inside a transport jar (fig. 20), the 10th such container from the site. Although different from the others because of its two ribbed handles and short stature, this (Cypriot?) pithos illustrated the usual merchandise: two White Slip II milkbowls packed inside a carinated bowl, fragments of White Shaved juglets, the most popular Cypriot type on board, and samples of every organic substance already attested. More exceptional were two short lengths of rope and bits of twine, bone game pieces, and a beautifully carved

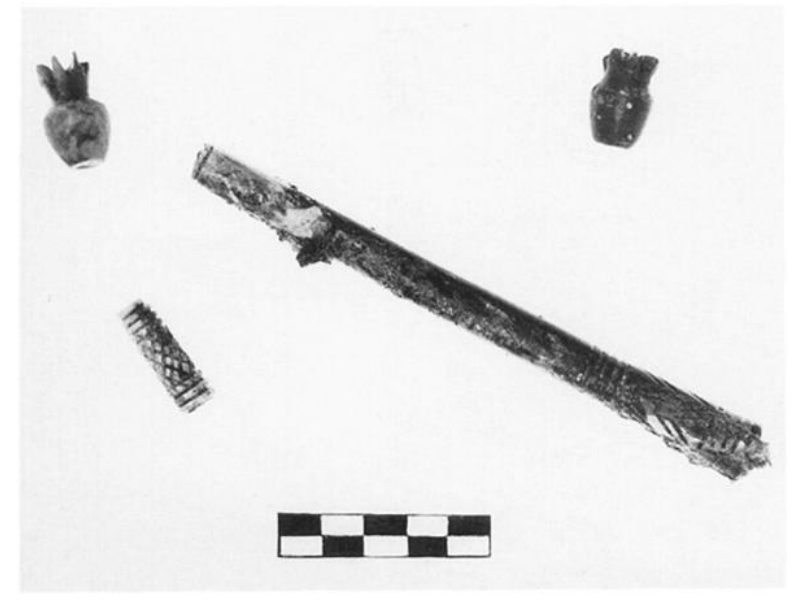

Fig. 19. Uluburun. Ivory finials. (Photo L. Ray Martin) 


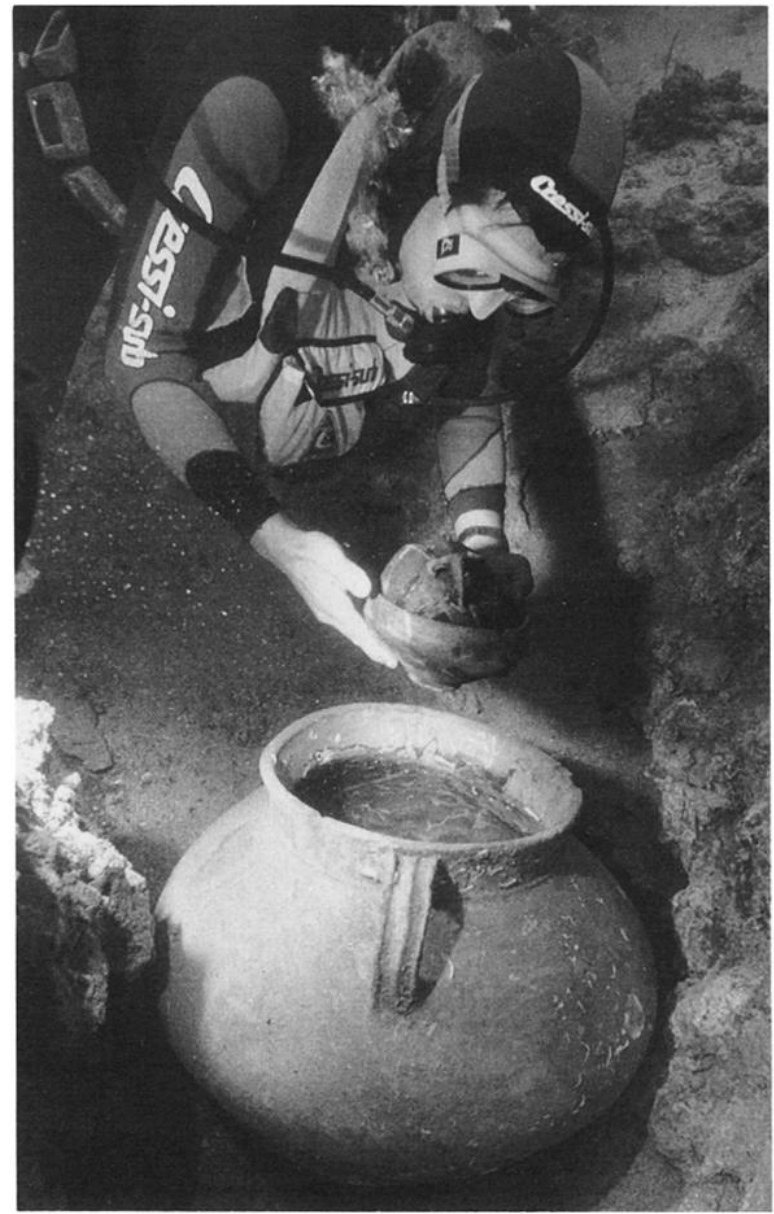

Fig. 20. Uluburun. Large pithos with Cypriot tableware. (Photo R. Piercy)

wood lid for an oval box. Resting against the shoulder of the pithos was one leaf from a diptych, iden. tical in appearance to the complete example recovered in 1988, but missing its ivory hinges and second leaf.

"Personal equipment for the crew still suggests a Syro-Palestinian origin for the ship: the galley wares, for example, and most of the tools, weapons, and items such as pan-balance weights (numbering over 130: two pans in a wooden case were found in 1993) and saucer lamps (the Cypriot lamps, in contrast, were unused stock for sale). Two more cylinder seals, one of them in Mittani common style, also support this identification. There were, however, some nonLevantine personal vessels and seals - among them a second Mycenaean lentoid seal found in 1994-that could point to an international legation (commercial attachés?) bearing royal gifts, rather than simply traveling salesmen of different nationalities shipping luxury goods as part of their inventory.

"The second goal of the season focused on the excavation, planning, and complete recovery of all the

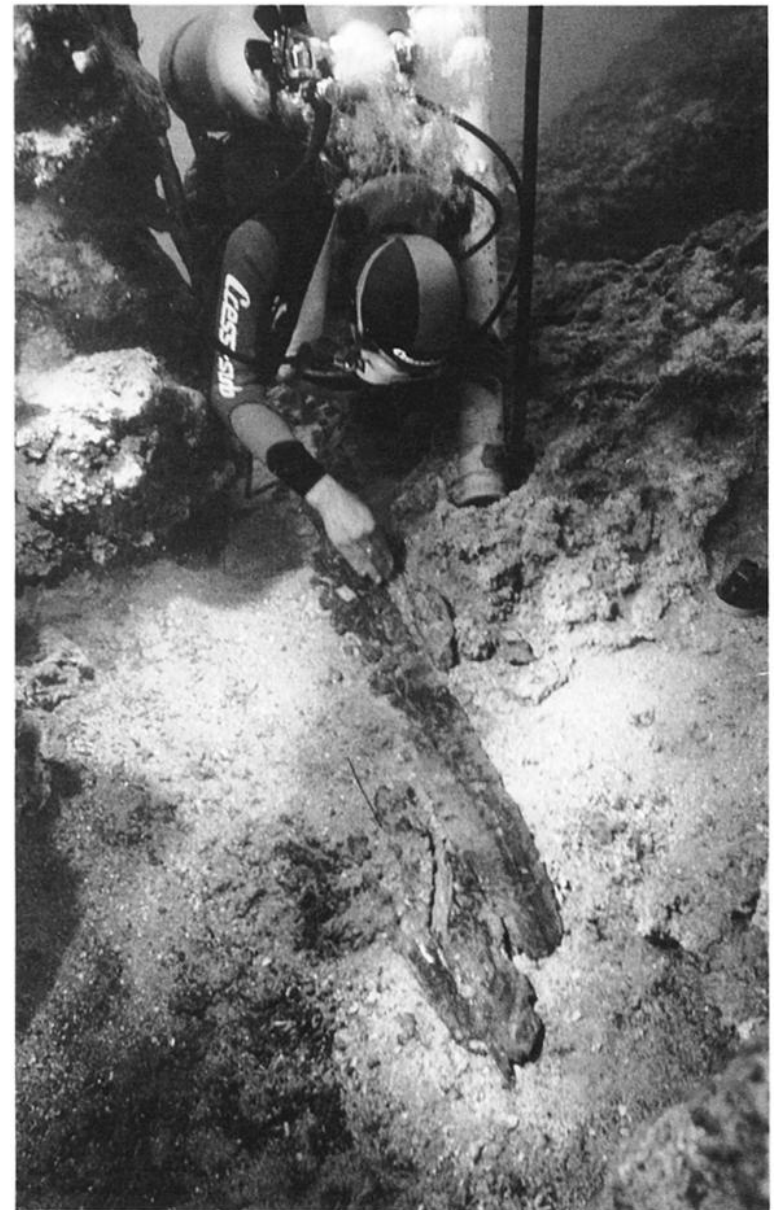

Fig. 21. Uluburun. Ship’s sweeps or oars. (Courtesy C. Pulak)

hull remains; and on reconstructing, by means of a three-dimensional, computerized topographic map of the site, the stages by which the ship broke apart and came to rest on the steeply sloping ocean floor. Sections of the hull at the deepest end of the wreck preserved an important construction feature not previously recovered: perhaps the approach to the bow, as indicated by a slight taper produced by a flat scarf or drop strake. Here were also found a section of the keel-plank and portions of six alternating wide and narrow starboard strakes. In the area of the withies excavated in 1993, several pieces of lighterweight wood may prove to be blades from the ship's sweeps, or oars from the ship's tender (fig. 21). Because the wreck's structural wood has warped into the shapes of the seabed, information from the topographical plan in conjunction with the remains themselves will ultimately make it possible to determine the ship's appearance and cargo placement when it set sail on its last journey.

"Dating the ship's final voyage more precisely may depend in large part on dendrochronological analy. 
sis. So far, the wood used for its construction is sug. gesting the last quarter of the 14th century B.C., and it is hoped that additional samples collected in 1994, including the keel-plank, will refine the date further. This will provide cross-dating of great significance for the Uluburun artifacts, whose conservation and study - after this lengthy fieldwork - now become the project's focus."

Preliminary reports for 1992-1993 are published in KST 15:1 (1994) 375-97 and 16:1 (1995) 219-37; for the 1994 season, and the 1993-1994 regional ship. wreck surveys, see INA Quarterly 21:4 (1994) 8-16. An article on LB organic cargoes by C. Haldane has appeared in WorldArch 24 (1993) 348-60.

\section{METALLURGY}

Gölțepe and Kestel (Niğde). K. Aslıhan Yener's progress report on the 1993 season at the EB and Iron Age mining center of Göltepe and the neighboring Kestel mines appears in KST 16:1 (1995) 177-88. No excavations were undertaken in 1994. B. Earl's most recent replication experiments for smelting tin are presented in The Oriental Institute News and Notes 146 (1995) 1-5. For a general study on tin mining in Anatolia, see E. Kaptan, "Tin and Ancient Mining in Turkey," Anatolica 21 (1995) 197-204.

\section{DENDROCHRONOLOGY}

Peter Kuniholm and his team collected over 500 samples in 1994 for analysis at the Carolyn and Malcolm Wiener Laboratory for Aegean and Near Eastern Dendrochronology, whose tree-ring sequences now span over 6,000 years from both sides of the Adriatic to Syria. Newly calculated dates relevant to specific Anatolian sites discussed in this newsletter have been included in the site summaries. Of particular interest for second-millennium absolute dating is a sample from Porsuk with an anomalous ring that Kuniholm attributes to the climatic disturbances brought on by the Thera eruption in 1628 B.C. This sample would obviate the Mesopotamian "High Chronology," and perhaps favor the "Low Chronology." He presents the 1992 and 1993 project results in ArkST 9 (1994) 281-91, and a general assessment in AJA 99 (1995) 99-102.

\section{ARCHAEOBOTANY, PALYNOLOGY, PALAEOZOOLOGY}

Discussions of archaeobotany (N. Miller), palynology (S. Bottema), and palaeozoology (H. Hongo and R.H. Meadow), with particular reference to Anatolian archaeology, can be found in P.E. McGovern, "Science in Archaeology: A Review," AJA 99 (1995) 91-99. M. Nesbitt's excellent summary of archaeobotany, agriculture, and diet in ancient Anatolia appears in BiblArch 58:2 (1995) 68-81 (the map on p. 79 should be used with caution, however); and in a Turkish translation in Bilim ve Teknik 336 (1995) 26-29.

\section{IRON AGE}

\section{Eastern Anatolia}

Anzaf. Progress in recovering the plan of the ninth-century B.C. Urartian military complex built by King Ishpuini to protect a strategic crossroad east of Lake Van was assisted by aerial photographs that revealed additional features of the lower fortress's enclosure circuit. Oktay Belli was able to identify and excavate a large bastion on the northern side, where a monumental gate was protected by an interior tower. Wall foundations of dense rubble supported well-preserved mudbrick superstructures, their faces carefully plastered. Just inside the gate, hundreds of animal bones were lying in heaps on top of two iron axes. Interim reports on this site, which must have served in a double capacity as tax collection center, appear in KST 15:1 (1994) 417-44 and 16:1 (1995) 287-312. Recent installments in the long-term documentation of the region's Urartian dams and sophisticated water supply system can be found in ArassST 12 (1995) 353-83, and TelAviv 21:1 (1994) 77-116. Fourteen dams, some of them marked with royal inscriptions, have now been located to the north, northeast, east, and southeast of Van.

Ayanis Kalesi. Altan Çilingiroğlu's 1994 campaign at the seventh-century B.C. fortress founded by Rusa II continued work in the previous seasons' excavation areas. The circuit wall's superb andesite masonry has been exposed along the entire eastern side and much of the southeastern side, revealing details such as vertical channels to help drainage at the corner joints of the blocks. Proceeding further inside the monumental southeastern gate, where Rusa II's building inscription was discovered in 1993, it was found that the back had, at a later stage, been blocked with brickwork, and a much smaller door had been pierced on the side to control traffic more effectively.

On the upper citadel, more of the great pillared hall was cleared: there were three rows of massive orthostat-lined piers to support the high ceiling (the mudbrick walls are preserved to a height of $4 \mathrm{~m}$ ). Quantities of collapsed pine roof beams, many with mortises that should allow the reconstruction of the roofing system, still suggest a dendrochronological date in the middle of both the century and Rusa's reign. On the west side, the plan of the great warehouse ("pithos building") was expanded. A sophisticated drainage system was discovered under the long cobbled corridor that separates the large pithos storeroom from the narrow wing of magazines. It consists of tapering terracotta pipes fitted end to end and sealed with lead; a T-shaped pipe also gave 
access into the drain. Inside the storeroom, brick steps gave access either to an upper floor or high shelving. To the numerous bullae found here can now be added an Urartian tablet, the 33rd known so far. A second storage structure with 2-m-tall pithoi surrounded by small, standard-sized handleless jars is also being uncovered underlying a Medieval cemetery near the pillared building.

A progress report on the 1992 season is presented in KST 15:1 (1994) 445-56. Çilingiroğlu discusses decorated stone vessels from Ayanis in TelAviv 21:1 (1994) 68-76. For an assessment of Rusa II's building program, see P. Zimansky, "An Urartian Ozymandias," BiblArch 58:2 (1995) 94-100.

Karagündüz-Van. The salvage project of previous seasons to document the Urartian necropolis on Erçek Lake's eastern shore, $35 \mathrm{~km}$ north-northeast of Van, was reoriented by Veli Sevin in 1994 to the mound proper, when a rise in water level isolated it on a promontory and indeed threatens to submerge it. Three soundings produced a long sequence of occupational deposits. Immediately below the Medieval cemetery that crowns the site, the stone foundations of a large building were found together with red ceramics decorated in black paint - the first time that this ware, known from Hasanlu IIIB, can be associated with an architectural context in this region. Deeper in the soundings, a mixed level with Caucasian Haftavan VIB painted wares signals a secondmillennium occupation. The lowest phase reached during the season contained EB Transcaucasian graphite wares like those from Sos Höyük, together with red-and black-burnished Karaz pottery, but no associated architecture.

Excavations were also carried out at the newly created shoreline a few kilometers to the east of the mound, where a low $20 \cdot \mathrm{m} \cdot$ long oval feature in a field of tumuli proved to be a massive rectangular brick platform, its plastered floor painted with brown, blue, and pink designs outlined in black. This structure, although burnt, produced no finds beyond a terracotta spindle whorl and some iron nails. It recalls the temple at Altintepe, and may have functioned as a ceremonial center for the surrounding cemetery. The tombs date to the early Iron Age/early Urartian period, and illustrate fully a pottery repertoire distinct from the Urmian version of this culture.

The 1992-1993 seasons at the Karagündüz necropolis are summarized in KST 16:1 (1995) 331-50. For C.A. Burney's soundings on the mound in the $1950 \mathrm{~s}$, see AnatSt 8 (1958) 157-209.

İmikuşağı. Veli Sevin has published the first final report on the first-millennium phases of his salvage excavations in the Malatya area as $\dot{I m i k u s ̧ a g ̆ \imath ~ I ~(A n k a r a ~}$ 1995).
Cilicia

Karatepe and Domuztepe. In 1994 Halet Çambel continued her program of restorations on the Karatepe citadel; and excavations at Domuztepe, where the street leading inside the fortress gate was followed further into the Iron Age residential district investigated in previous seasons. The very burnt houses here contain a full selection of kitchen equip ment. Evidence for corbeled vaulting to roof the gate was also discovered.

The 1991/1992 report (KST 15:1 [1994] 309-23) includes photographs of the restored monumental statue of a storm god that was reerected in 1991 beside Karatepe's southern gate.

Kinet Höyük. See above, under "Chalcolithic and Bronze Age, Southeastern Anatolia and Cilicia.”

\section{Central and Western Anatolia}

Gordion. The 1994 season, under the guidance of G. Kenneth Sams, again involved a broad range of issues, from conservation to stratigraphy and settlement variations, ethnoarchaeology, and publication projects. After a decade of disappointing experiments on mudbrick preservation, it was finally decided to rebury Megaron 1, and replicate it on a platform in the same location. The stone walls of Terrace Building IV were rerestored by replacing the earlier mortar capping with a rusticated mortar and stone layer. These techniques will be applied to other structures.

Excavations directed by Mary M. Voigt were carried out in three separate areas. Gordion's later residen. tial phases were investigated on the western side of the citadel mound, in the $1950 \mathrm{~T}$ Trenches. Late Phrygian walling was found to have been constructed on top of the usual 3.5.m-thick clay seal; but the clay had been laid down over rubble packing or terrac. ing rather than over burnt buildings, as in the center of the mound. This architectural level was followed by two substantial phases of Hellenistic housing with elegant ashlar foundations, the stones occasionally recycled by the less impressive Galatian occupation that followed. A Roman house marks the end of the sequence. During the latter periods, the saddle between the citadel mound and the "Küçük Höyük" was used as a cemetery. The Roman cremation and inhumation burials excavated there in 1994 included an adult female wearing, around her neck, a large bronze signet ring wrapped with string (a memento from someone with much thicker fingers?). Its engraved bezel is decorated with a fisherman brandishing his catch (fig. 22). The Galatian settlers put this area to a related but altogether more dramatic use for ritual sacrifices of animals (equids and bovids), women, and children. Skeletons-some de. 


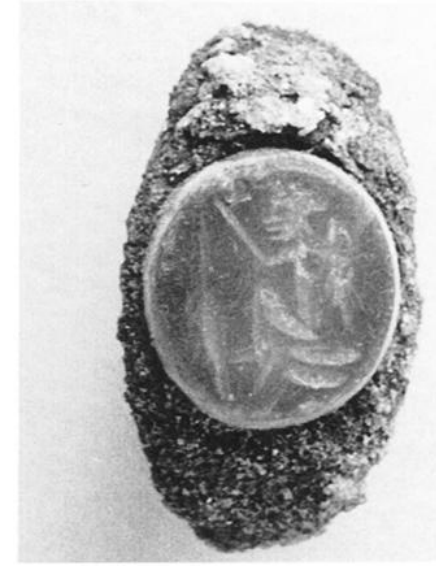

Fig. 22. Gordion. Bronze signet ring from Roman burial. (Courtesy M.M. Voigt)

capitated, some with broken necks-were found strewn throughout the excavated area; they had evidently been left exposed rather than buried in pits.

On the western side of the site, overlooking the present course of the Sakarya, a step trench down the side of the mound and two soundings near the river uncovered stratified remains of Middle and especially Late Phrygian date, followed by an Achaemenid phase that includes imported Iranian pottery. A nondomestic structure spanning the Middle to Late Phrygian periods was filled with arrowheads and, among other finds, an incised ivory plaque showing a running warrior with a sword and shield (fig. 23). The houses on this side were large and well appointed with the Attic and Lydian pottery that characterizes the city's taste for refined tableware. Imported prod. ucts continued to flood in from the west in Hellenistic times as well, now documented by research on the amphoras that transported wine and oil from Rhodes, Miletos, Mendes, Thasos, and Chios to Gordion.

For the 1992 and 1993 season reports, see KST 15:1 (1994) 467-79 and 16:1 (1995) 369-92. R.C. Hendrickson discusses the Hittite ceramic industry at Gordion in BiblArch 58:2 (1995) 82-90; the Iron Age pottery in D. French and A. Çilingiroğlu eds., Anatolian Iron Ages 3 (London 1994) 95-129; and Gordion's Bronze and Iron Age ceramic traditions in W.D. Kingery ed., Social and Cultural Contexts of New Ceramic Technologies (Westerville 1993) 89-176. The 1988-1989 seasons' stratigraphic soundings are published by M.M. Voigt in Anatolian Iron Ages 3, 265-93. Volume II has appeared in The Gordion Excavations (1950-1973), Final Reports series edited by G.K. Sams: E.L. Kohler, The Lesser Phrygian Tumuli, Pt. 1: The Inhumations (Philadelphia 1995).

Kerkenes Dağ. Geoffrey Summers, Middle East Technical University, Ankara, concluded his second season of aerial and geophysical survey at this Late

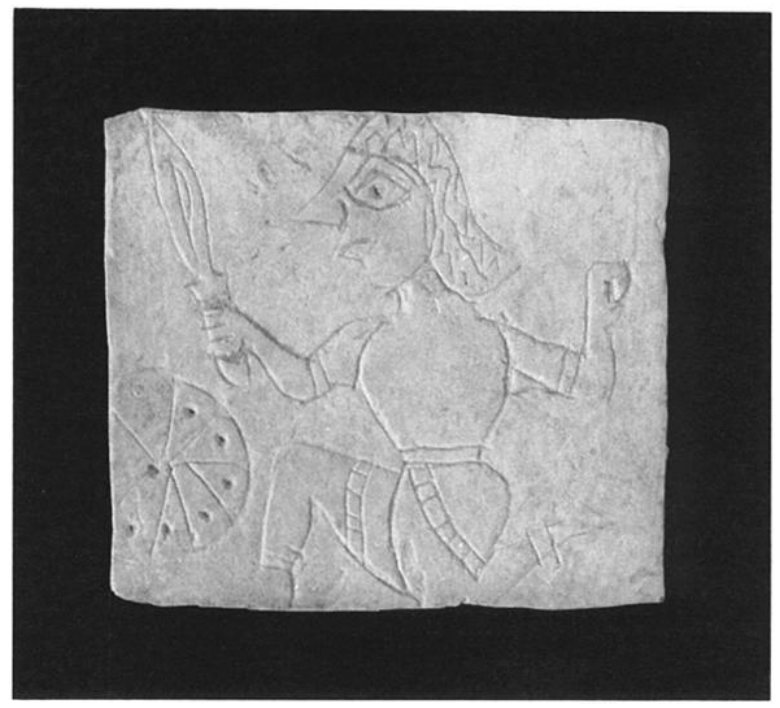

Fig. 23. Gordion. Lower Town. Middle-Late Phrygian ivory plaque. (Courtesy M.M. Voigt)

Iron Age fortified site east of Yozgat, 1,400 masl in the northern Cappadocian highlands, with a complete photographic record taken from both a hot-air balloon and helium blimp. Topographic plans made on the ground are being coordinated with the photographic documentation to produce a computerassisted planimetric map. The layout of the entire 375 -ha site $(2.5 \times 1.5 \mathrm{~km})$ can already be assessed for specific structural features and overall plan. He kindly reports:

"Oblique shots from the blimp (fig. 24), which proved more successful in highlighting architectural remains than the vertical pictures needed for mapping, defined with more precision an important complex on the southern side of the site near one of its many gates. Here, a network of streets led to a triangular open area, perhaps a plaza, faced by a monumental building set on a pair of huge rubble terraces and reached by a ramp or staircase. The streets were also flanked by large enclosures. Natural topography determined the placement of the entire settlement's streets and buildings, which were not oriented according to an imposed grid. Likewise, the massive defensive system, and the location of its gates followed the site's natural contours. Nonetheless, the site appears to have been created as a coherent building program that included elaborate provisions for sup. plying water. The survey suggests that construction was not yet finished when an intense fire destroyed the city, damaging far more buildings than previously realized. Tumuli were later erected both inside the abandoned site and in the surrounding region, a burial tradition now recognized as spanning sev. eral periods and a variety of types, all different from the Phrygian type with timber chambers. 


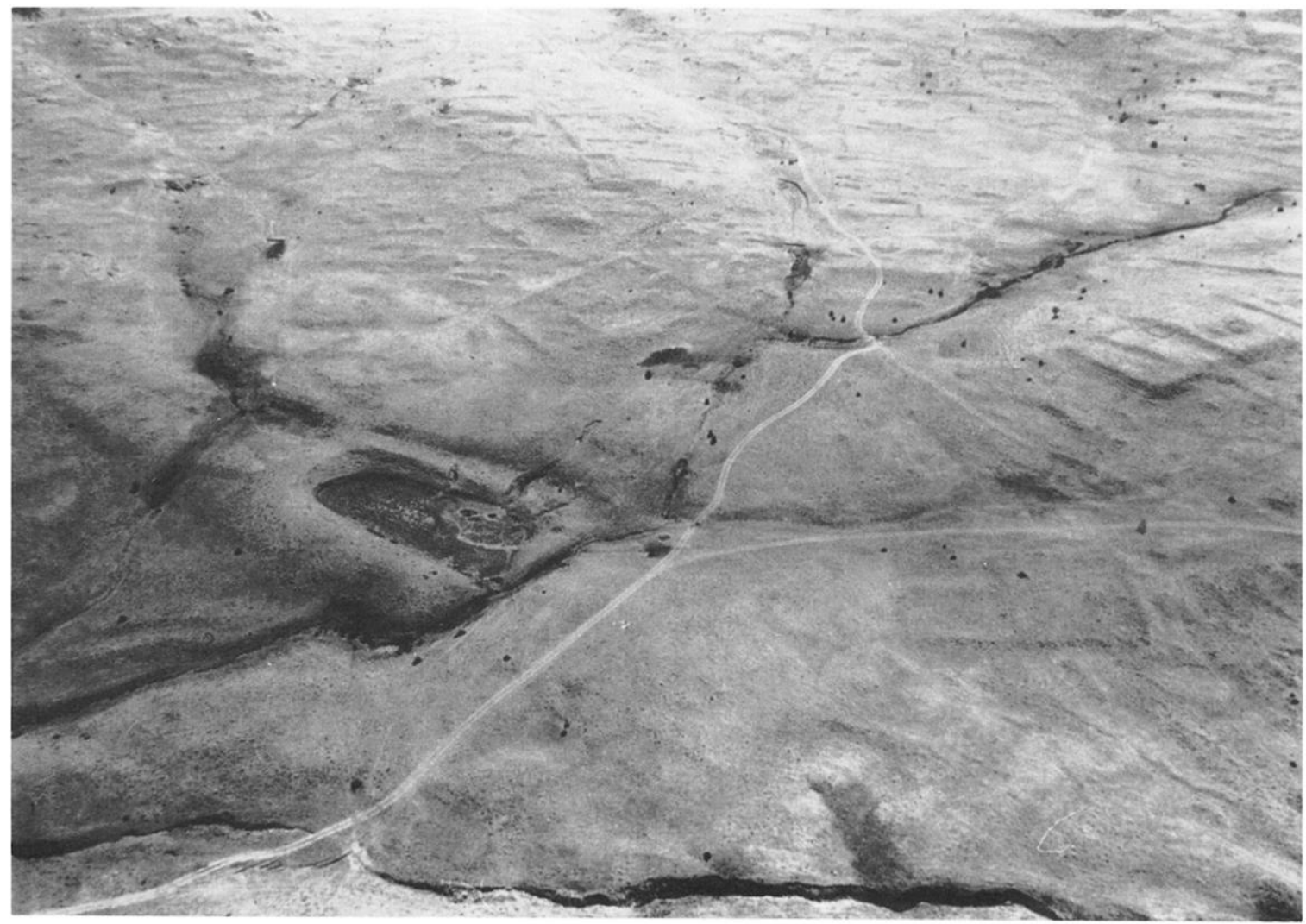

Fig. 24. Kerkenes Dağ. Center of city, looking southeast, with largest of the artificial reservoirs. (Courtesy G. Summers)

"An extramural temple, $25 \mathrm{~m}^{2}$ with fieldstone walls at times preserved $3 \mathrm{~m}$ high, was identified 650 $m$ to the north of the fortified enclosure, and contemporary with it. The masonry includes corner buttresses bonded into the walls, a structural technique also used for attaching the fortification towers to the city wall at the main site. The temple's internal plan, although obscured at the back, contained at least three rooms, and seems to have been oriented toward the east."

The 1993 interim report on the site, which the excavator identifies with the Median fortress Pteria, appears in AraşST 12 (1995) 567-82; for 1994, see AnatSt 44 (1994) 15 and British Institute of Archaeology/ Ankara Research Reports 1994, 18-20.

Göllüdağ. Wulf Schirmer carried out a third season of aerial photography, mapping, and soundings in 1994 at the second Cappadocian Iron Age fortified hill site that is currently being studied. Göllüdağ also appears to have been laid out as a unified building program, perhaps under the auspices of the kings of Tabal, in the late eighth century B.C. Unlike at Kerkenes Dağ, however, natural topography determined only the placement of the fortification walls, which enclose a 150-ha area on the ridges of a volcanic crater 2,000 masl. The city's buildings, especially the monumental complex and its associated structures on the central ridge, followed a strict orthogonal system with only minor concessions to irregularities in the terrain.

Closer investigation of the fortification walls revealed the presence of 80 small towers, many connected with minor entrances, in counterpoint to the major gates located on all four sides. Soundings in two separate areas of the central ridge also allowed a closer assessment of its architectural features than aerial photography had previously afforded. A unit of eight double cells, typical of the architectural blocks on the southeastern side of the complex, was completely cleared. The blocks were organized in two rows of four cells sharing a common back wall, but without communicating doorways: each cell was entered through a single door that opened onto the street. The second type of unit, with communicating cells arranged on two sides of a courtyard, was sampled to the northeast of the complex in the long block parallel to the city wall. In both areas the rooms were bare of any pottery or finds, but must have served as (temporary?) housing. Since the entrances to the central complex were once decorated with lion sculptures (now in the Niğde Museum) and the main city gate was also flanked with lions (taken to the Kayseri Museum by R.O. Arık), the entire city with its monumental architecture and associated housing 
must have served a special, formal, and non-military function.

Gâvurkalesi, Kaman-Kalehöyük. For the Iron Age phases, see above, under "Chalcolithic and Bronze Age: Eastern, Northern, and Central Anatolia."

Pessinus. For the Phrygian phase, see below, under "Classical, Hellenistic, and Roman: Phrygia."

Şarhöyük-Dorylaion. A. Muhibbe Darga has summarized the results of her first four seasons (19891992) at the Bronze Age, Phrygian, and later site on the outskirts of Eskişehir in KST 15:1 (1994) 481-501, and the 1993 campaign in KST 16:1 (1995) 351-67.

\section{CLASSICAL, HELLENISTIC, AND ROMAN}

\section{Pamphylia, Pisidia}

Perge. Excavations under the direction of Haluk Abbasoğlu continued for a third season to investigate the Late Roman and Byzantine residential district immediately inside the city gate, where insulae were laid out with four houses per block. To the west of the earlier campaigns' trenches was found a wellpreserved two-storied house organized around a large courtyard, with mosaic floors and an oil press. Finds include quantities of glass, such as sixth/seventh century A.D. lamps with suspension loops similar to those shown hanging above shop fronts in illuminated Byzantine manuscripts. Since the houses were built directly on bedrock, it is now clear that this district reflects a final expansion of the city in Late Roman times (third century A.D.), and continued prosperity throughout the Early Byzantine period, until the Arab raids in the seventh and eighth centuries.

Efforts to locate traces of pre-Classical settlements in the area prompted renewed survey on the acropolis. Although surface clearing uncovered primarily Hellenistic remains - walling and paved roads leading to the lower city-sporadic finds give glimpses of earlier periods: a flexed burial with chipped stone arrowheads as grave goods; sherds of sixth-century Attic black-figure; and a fifth-century lion-headed drainspout reused in a Late Roman wall. Other efforts focused on contemporary problems, in particular the protection of the necropolis from illegal digging. For a 1991 progress report, see KST 15:2 (1994) 597-611.

Side. The restoration program on the theater and the adjacent agora entered its second decade under the direction of Ülkü Izmirligil. Progress into the diazoma of the theater has located internal staircases that will permit an evaluation of how spectators circulated throughout the building. Other traffic flowsnotably of today's tourists through the ancient siteare causing the archaeologists far more difficulties, and underscore the potential for conflict between the tourism industry and archaeological research. The 1993 season is discussed in KST 15:2 (1994) 243-52.

Sagalassos. The 1994 season in the Pisidian highlands successfully expanded the impressive scale of the four previous campaigns thanks to an even larger interdisciplinary crew engaged in excavation, conservation, survey, ethnography, and the study of ancient diets, export networks, and the changing landscape. Marc Waelkens, Catholic University, Louvain, kindly reports:

"Excavations to the north of the Late Hellenistic fountain in the area of the Roman library were carried out with the dual purpose of investigating its still active water source and preparing the monument's restoration. A sixth-century A.D. water supply system was discovered, as well as the Late Hellenistic and Roman ones that it adapted. The Byzantine version consisted of a series of settling tanks feeding three terracotta pipes cut through the fountain's back wall. The water was then transferred west into a preexisting vaulted service tunnel $1.5 \mathrm{~m}$ high, and from there into an enormous tank near the southwestern corner of the fountain house. The tunnel was itself replacing a Late Hellenistic predecessor with a corbeled roof built of fieldstones that we followed for $37 \mathrm{~m}$ before reaching a collapsed section. A terracotta channel in its floor would have assisted in directing the flow of water, ultimately to the Upper Agora. Access to the tunnel through a slab in the roof was blocked in the early third century A.D. when the slopes around the fountainhouse were leveled and paved to form an esplanade, requiring a reworking of the water distribution system.

"A second discovery stemming from preparations for the restoration of the library occurred to its west, where the previous season had uncovered a large room, suggesting that the library originally formed part of a building complex such as a gymnasium. This interpretation must now be reassessed. When this area was opened up in 1994, the large room was found to be one of a row of shops with mortared rubble walls and brick stringcourses dating to the second quarter of the second century A.D., probably at the same time as the library proper. They had gone out of use by the library's last restoration during the reign of the emperor Julian, but (as described in last year's report) served briefly as residential housing after the fire that destroyed the library in the later fourth century, and until the Isaurian raids of A.D. 404-406.

"The excavations this season in the Upper Agora moved on to the sequence of structures that delimited its northern 30-m-wide edge, and cleared its western half. The earliest building there, still standing 


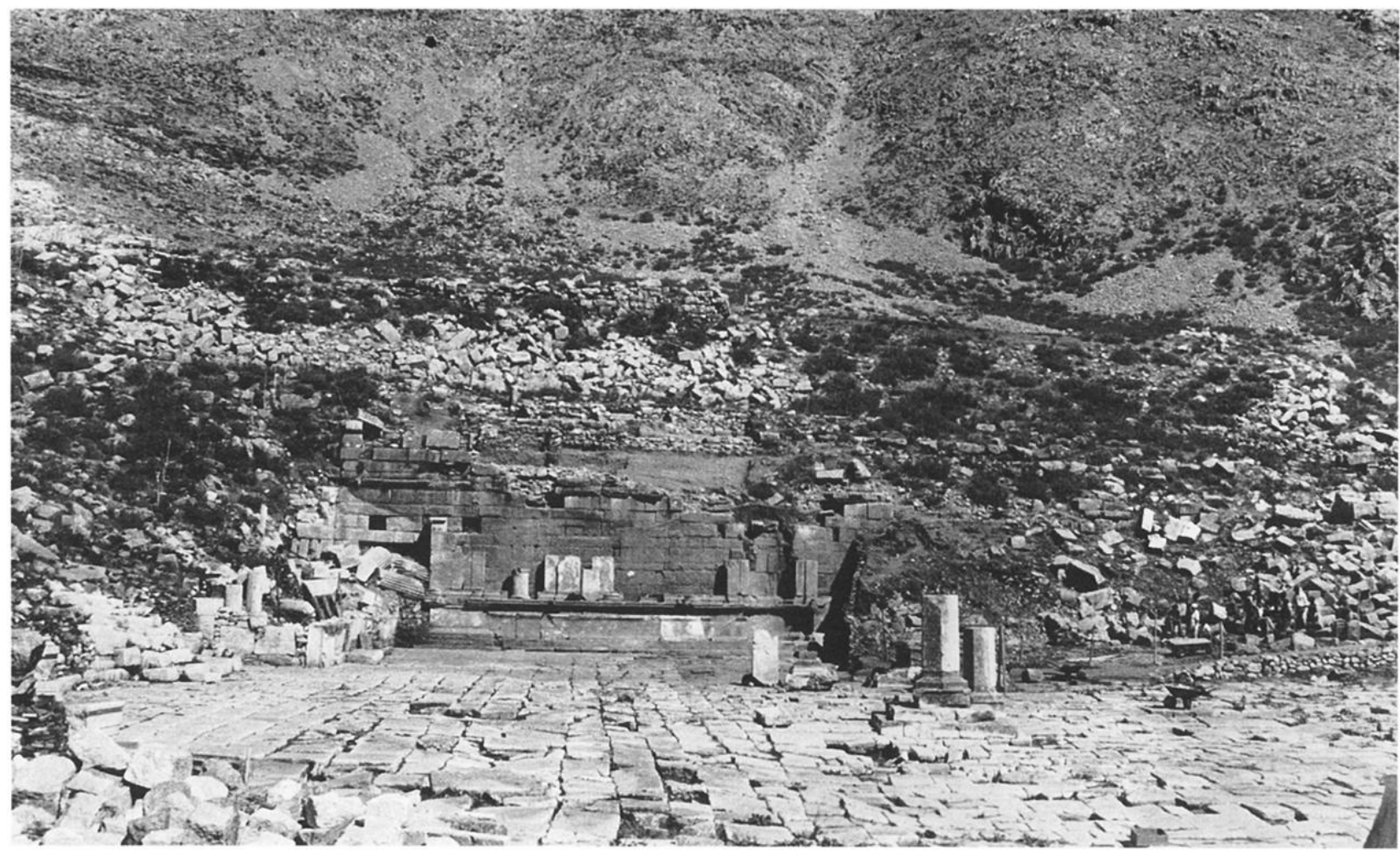

Fig. 25. Sagalassos. North side of Upper Agora, nymphaeum, western half exposed (A.D. 160-180). (Courtesy M. Waelkens)

$7 \mathrm{~m}$ high, was designed with a plain facade on two stories supporting an elaborately decorated third floor, most probably in the shape of a Doric portico. Structural features and associated "proto-Sagalassos ware" would suggest a construction date in the third quarter of the first century B.C. The facade was later backed by a thick layer of Roman concrete, and the floor level raised considerably some time in the second century, perhaps in connection with the construction in front of it of a large nymphaeum (fig. 25) that became the focus of the Agora's north side during the Antonine period (A.D. 160-180). The nymphaeum's aediculated theater facade, one story high, was set on a $1.50-\mathrm{m}$-tall podium in front of a rectangular basin with a capacity of $170 \mathrm{~m}^{3}$. The facade was articulated with six projecting podia on either side of five niches; a waterfall would originally have cascaded down the semicircular central one (fig. 26). Monumental marble sculptures were recovered from the four niches and podia excavated in 1994: from the end toward the center, a Dionysos and satyr pair in Aphrodisian marble (figs. 27-28); a fragmentary male torso; a complete Nemesis (fig. 29) apparently brought in from elsewhere and for whom the niche was modified; and the feet of an Artemis with cuttings on the base for a bronze statuette. The nymphaeum was reworked on several occasions over the follow. ing 400 years. By the first half of the sixth century, it had been divided over two terraces into small

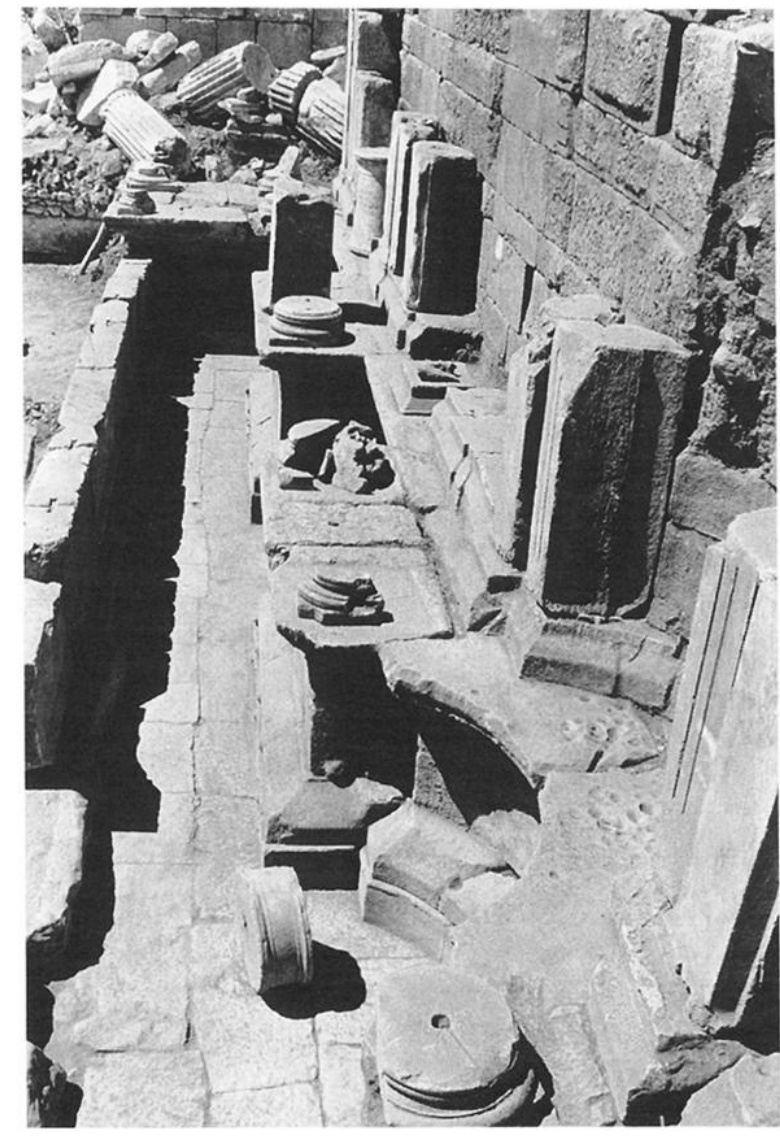

Fig. 26. Sagalassos. North side of Upper Agora, nymphaeum facade, northwestern half. (Courtesy M. Waelkens) 


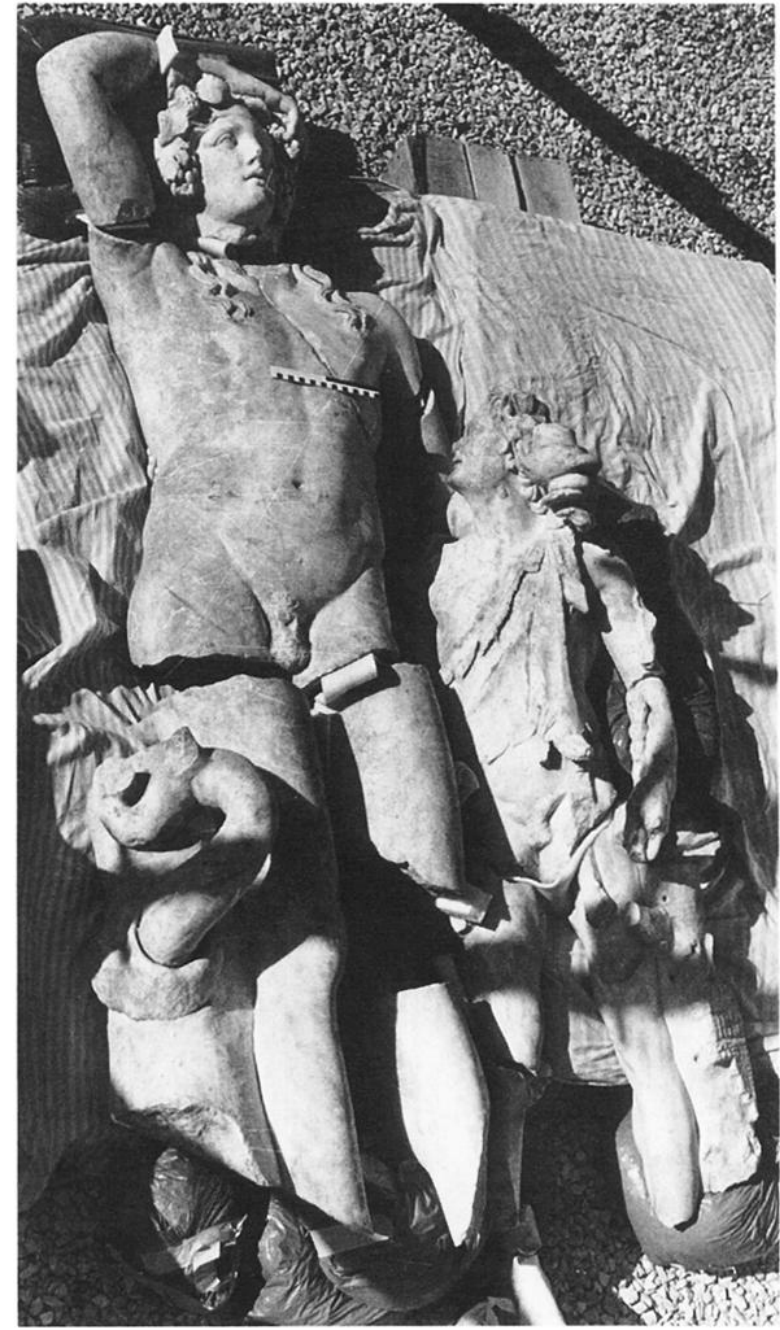

Fig. 27. Sagalassos. North side of Upper Agora: Dionysos and satyr group, from the nymphaeum. (Courtesy $M$. Waelkens)

rooms for storage or workshops that can be associated with two street levels. Coins indicate that the rooms were not abandoned before A.D. 640 .

"Northwest of the Upper Agora, excavations began anew northeast of the Kakasbos temple, in the place where R. Fleischer discovered eight frieze slabs with a chain of nearly life-size dancing girls over 20 years ago. The monument to which they belong proved to be a tall square socle, $7.5 \mathrm{~m}$ on a side and over $2.5 \mathrm{~m}$ high (its base was not reached in 1994). Three more slabs (fig. 30) representing another four dancing girls were recovered, as well as evidence for repairs to the frieze during the Roman period (fig. 31: Antonine head for the east corner dancer). The monument itself, however, can be identified as a Middle Hellenistic heroon, thanks to associated fragments from a nearly $4 \cdot \mathrm{m}$-tall marble sculpture of a $\mathrm{Hel}$ lenistic ruler. The head allows us to recognize him as a youthful Alexander the Great, portrayed in the

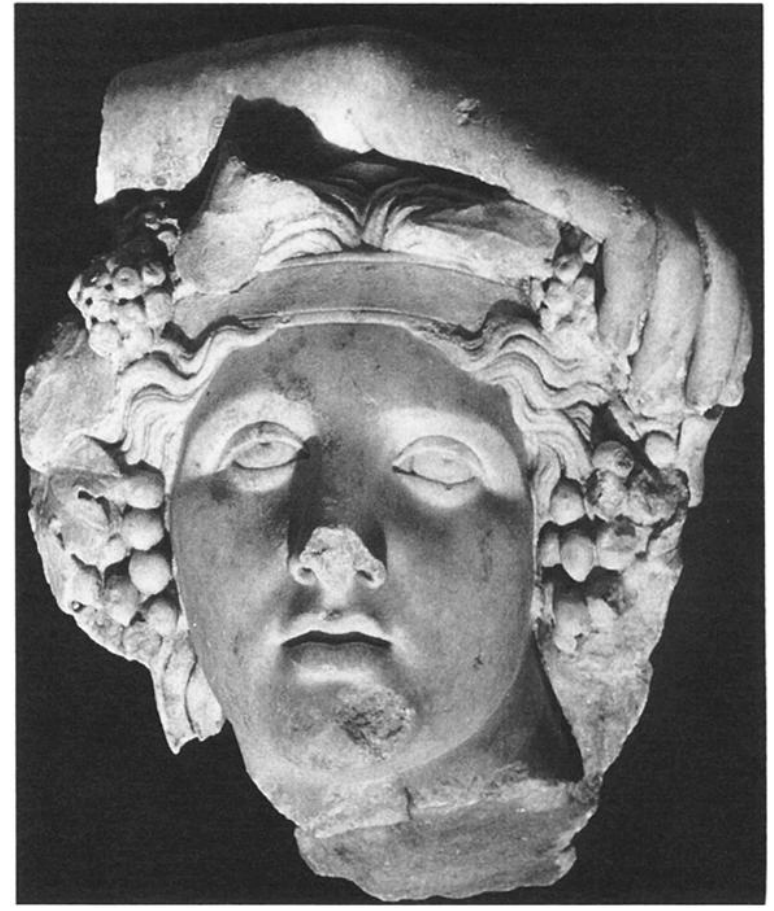

Fig. 28. Sagalassos. North side of Upper Agora, nymphaeum: detail of Dionysos head. (Courtesy M. Waelkens)

Polykleitan tradition, and positioned to overlook the plain where he engaged the Pisidians in battle.

"The third year of large-scale efforts in the Lower Agora included the initiation of work on the 840 $\mathrm{m}^{2}$ bath complex that was erected against its northeastern corner in the second century A.D. Over 300 blocks that had collapsed into the agora were removed to reveal part of the baths' western facade (fig. 32), which was revetted with large ashlars against a mortar and rubble core with brick string courses. A sounding inside the wall indicates that it is $4 \mathrm{~m}$ thick, suitable for supporting an enormous brick vault that is still partly standing. Restoration in the agora proper completed repositioning the pavement slabs and honorific monuments over the entire excavated area. A monumental gate dating to the reign of Tiberius was also discovered in the agora's southeastern corner: a single row of Corinthian columns with lateral podia supported an entablature carved with garlands and theatrical masks, and a finely carved cornice. It was modified ca. A.D. 400, when a broad stairway was built outside it leading to the city's main north-south street. The structure collapsed in the earthquake of A.D. 518 or 528, trapping several victims whose skeletons were found lying in the debris.

"Survey of the district recorded 19 new sites, ranging from the late Palaeolithic and Neolithic periods to Byzantine times. These include two Hellenistic fortified cities (fig. 33: Kepez Kalesi, perhaps ancient 


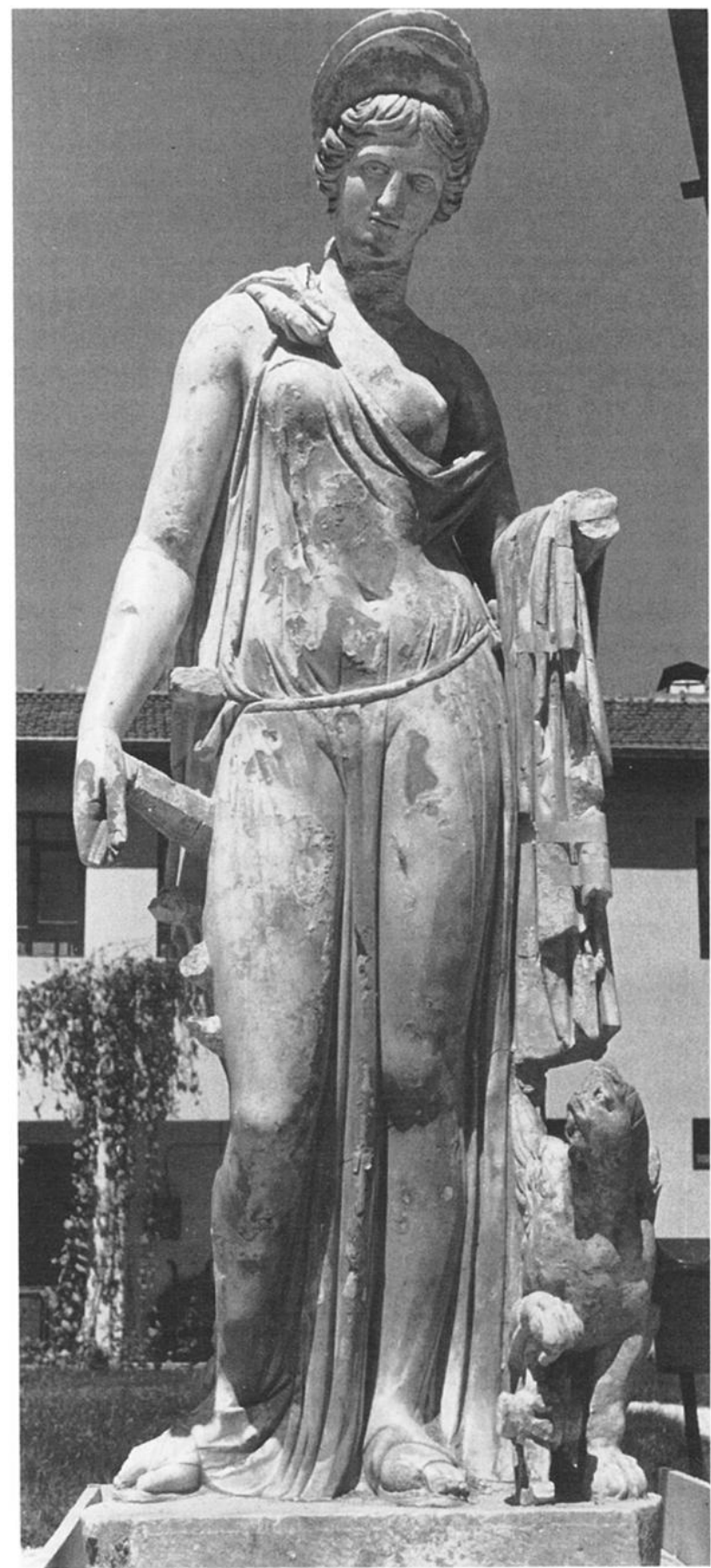

Fig. 29. Sagalassos. North side of Upper Agora: statue of Nemesis (ht. $2.10 \mathrm{~m}$ ), from the nymphaeum. (Courtesy M. Waelkens)

Paleopolis or Darsa); a Hellenistic fortress; and eight large settlements and an isolated sanctuary of Late Hellenistic-Early Imperial date."

A new display of finds from the 1990-1995 seasons, together with the restored Nemesis statue, has been set up in the Burdur Museum. A general report appears in Archaeology 48:3 (1995) 28-34, with a photograph of the Alexander head; for the 1992 and 1993 seasons, see KST 15:2 (1994) 373-407 and 16:2 (1995) 175-90, and AnatSt 44 (1994) 167-86. A study of Saga- lassos ware is presented by $\mathrm{J}$. Poblome et al. in $K S T$ 15:2 (1994) 408-18.

Balboura, Oenoanda. Reports giving the 1992 and 1993 results of these long-term surveys are presented by J.J. Coulton on the Balboura/Korkuteli region and neighboring Pisidian territory in ArasST 11 (1994) 429-36 and 12 (1995) 497-511, and AnatSt 44 (1994) 8-10, 129-48. L. Biers discusses the Upper Theater at Balboura in AnatSt 44 (1994) 27-46. For the 1994 research at Oenoanda, see S. Mitchell in British Institute of Archaeology/Ankara Research Reports 1994, 20-22. A parallel investigation in the Korkuteli plain with a focus on its prehistoric occupations was carried out in 1993 by M. Özsait (AraşST 12 [1995] 483-96).

Cremna. A final report on the survey has been published by S. Mitchell et al., Cremna in Pisidia: An Ancient City in Peace and War (London 1995).

\section{Lycia}

Limyra. In 1994, excavations were continued by Jürgen Borchhardt and his team on the ninth and tenth residential terraces located in the northern part of the site, where a system of plastered water channels was traced. The Roman phase was also investigated with soundings in the area of the porticoed street, and with a study of the Roman fort. The season produced six more fragments of the frieze with a chariot race and Persian war chariots that ornamented the Ptolemaion monument (see AJA 98 [1994] 264 fig. 9), an honorific type to which Xenophon refers. Restoration of the colossal female statue that once stood in this building has been completed. Conservation efforts have now turned to the Byzantine episcopal church, and to the necropolis. A more dramatic rescue involved the heroon, which was boxed up and transported from its high and isolated location down to the site museum by helicopter, reenacting, in Borchhardt's words, the feats of "a modern Pegasus for Bellerophon.” Reports on the 1992 and 1993 seasons appear in KST 15:2 (1994) 257-77 and 16:2 (1995) 229-51.

Letoon-Xanthos. No large-scale excavations took place during the 1994 season, which was devoted to soundings, survey, conservation, and study under the direction of Christian Le Roy. In the Letoon, how. ever, important new evidence for the layout of the temenos did emerge from soundings, demonstrating that its enclosure wall extended $70 \mathrm{~m}$ beyond the propylon. The size of the sanctuary can now be doubled from previous estimates, and the gate and the three temples can be relocated from its southern side to its center. Excavations in the stage and orchestra building of the Letoon theater began in the summer of 1995. 


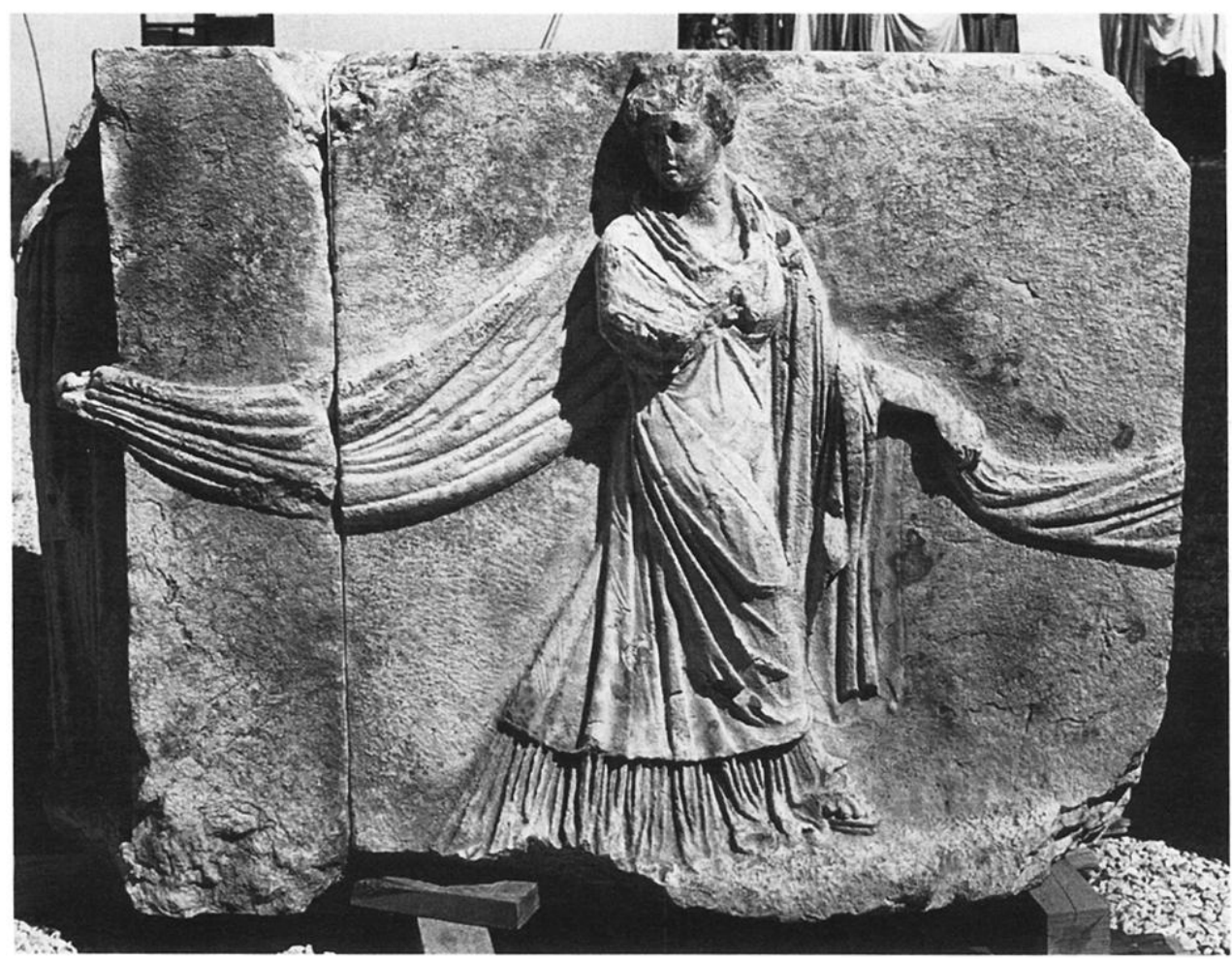

Fig. 30. Sagalassos. Hellenistic heroon: newly discovered frieze block from the eastern face. (Courtesy M. Waelkens)

Renewed investigations in the area of the necropolis, which was damaged in recent forest fires, discovered two large and elegant Late Antique (fifth century A.D.) villas with peristyles, fine mosaics, and architectural sculpture. In another successful survey venture, the Hellenistic and Roman aqueduct, which supplied the Xanthos bath complex, was followed back from its terminus and across three bridges to a mountain spring $8 \mathrm{~km}$ away near Çavdırköyü. Its small spring building was fed by a long tunnel with an interior walkway and channel. The hinterland network of peak fortresses linked by an extensive wall system was also documented further.

Ceramic research focused on the late amphora trade, and on the Medieval handmade pottery, whose clays have been traced to sources in the immediate vicinity and near Fethiye. The long-term restoration project at Xanthos proper has had to extend its attention to the more recent damage inflicted by an insensitive municipality's roadwork around the Antiochus Gate, and satellite dishes installed in and above the Byzantine monastic complex on the upper acropolis. An interim report on the 1991 and 1992 seasons appears in KST 15:2 (1994) 303-23.

Patara. Fahri Işık and his collaborators continued the previous seasons' research and restoration of the Roman baths, the Byzantine basilica (whose plan resembles one at Perge), and the ancient city's main street; they also excavated Byzantine graves with bronze crosses among the funerary goods, and a row of gabled Lycian sarcophagi dating to the Archaic period, and were able to recover most of the inscribed blocks from an Early Imperial monument that was entirely recycled into a Byzantine structure. Its nearly complete inscription, $5.5 \mathrm{~m}$ high and estimated at $60 \mathrm{~m}$ long, was carved in Greek on 53 separate blocks (only four are missing). The monument was dedicated to the emperor Claudius by $Q$. Veranius, the first known military governor of this region. Of enormous interest is the list of all roads connecting Patara to the other towns, here given Roman place names, in the district under Veranius's administration. The inscription is being published by Sencer Şahin. For the 1992 and 1993 interim reports with many illustrations, see KST 15:2 (1994) 279-301 and 16:2 (1995) 253-82.

Arycanda. Excavations directed by Cevdet Bayburtluoğlu concentrated in 1994 on the late residential phases of the site. On the central terrace, beside the honorific funerary monument opposite the library, was found a public latrine furnished with a room for a fee-collector. To its west, the usual sequence of Late Byzantine squatters' housing succeeded earlier Byzantine levels with more prosperous residences; so too on the southern terrace, where the lower level was represented by an Early Byzantine villa with geometric floor mosaics. Restorations were carried out in various parts of the site. Reports 


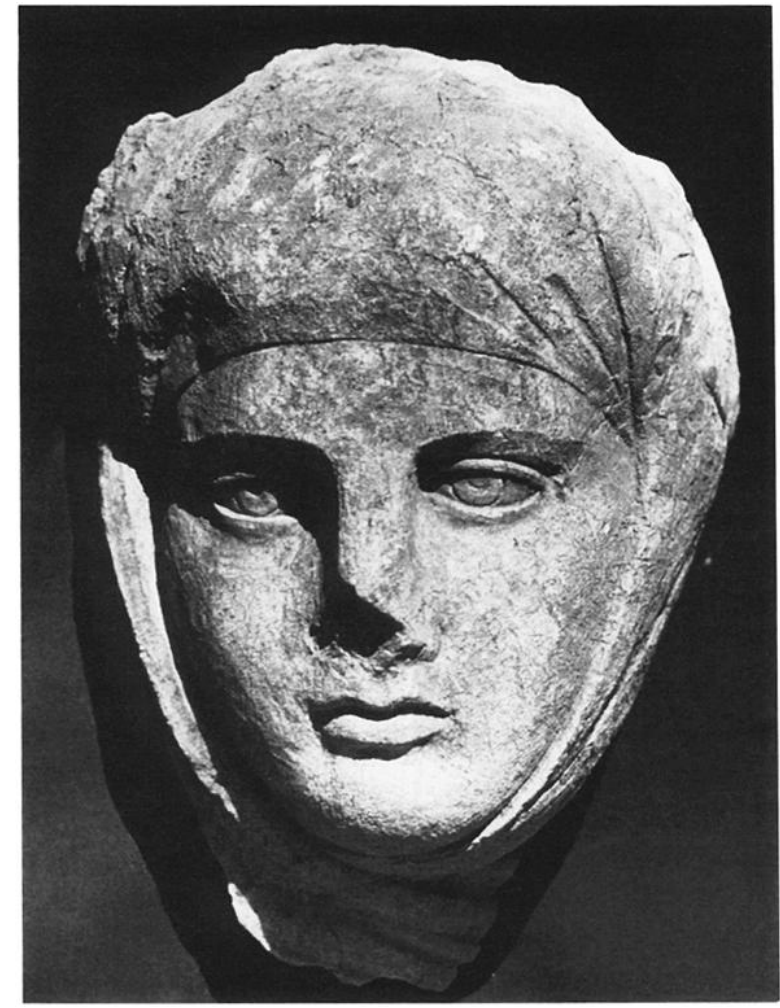

Fig. 31. Sagalassos. Hellenistic heroon: Roman repair (second century A.D.) for the eastern corner figure of the frieze. (Courtesy M. Waelkens)

are published in KST 15:2 (1994) 253-55 and 16:2 (1995) 217-27. Inscriptional material appears in a volume edited by S. Şahin: Die Inschriften von Arykanda (Inschriften griechischer Städte aus Kleinasien 48, Bonn 1994).

Hacimusalar-Elmalı. A new excavation project under the direction of İlknur Özgen was inaugurated in 1994 at the largest mound $(300 \times 300 \mathrm{~m}$, and $13 \mathrm{~m}$ high) in the central Lycian plateau, $20 \mathrm{~km}$ southwest of Elmalı near Akçay. The site was originally located on the shores of a large lake (recently drained), where it could control the major passage from the plateau south to the sea, as well as east and west across Lycia-indeed, the role today enjoyed by nearby Elmalı for a route that the surrounding mountains have kept unchanged since antiquity. Cedar forests, excellent hunting and fishing, and the agricultural richness of a well-watered plain ensured the site's prosperity from Late Neolithic/Early Chalcolithic times to the Byzantine period, and its development into the area's only major ancient city. It has tentatively been identified with Byzantine Choma.

This project represents the first attempt to investigate ancient urbanism in this plain. It is thus intended to supplement and follow upon previous archaeological research here - notably at Bronze Age Karataş-Semayük, the Archaic painted tombs at

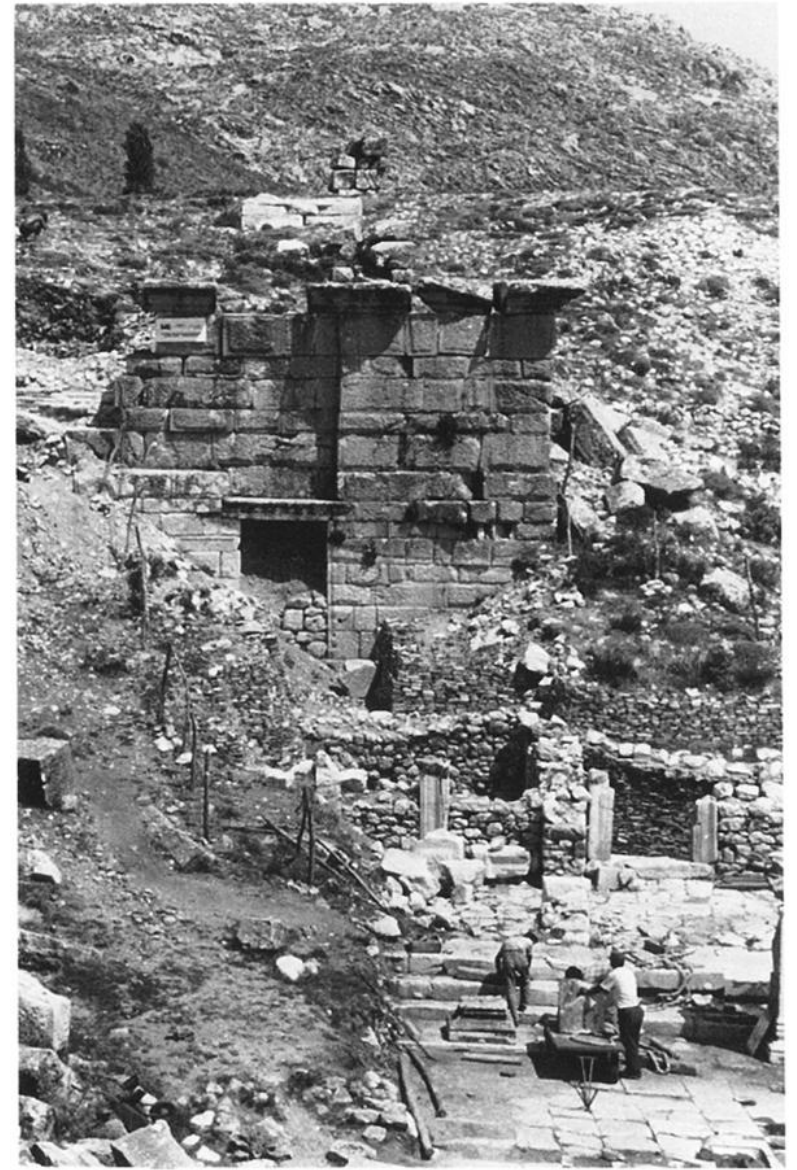

Fig. 32. Sagalassos. Partial view of a Roman bath building beside the Lower Agora, at close of the 1994 season. (Courtesy M. Waelkens)

Kizilbel and Karabel, and the Iron Age Bayındır tumuli. A survey in 1993 and soundings in 1994 produced evidence for its later Hellenistic, Roman, and Byzantine phases, together with earlier pottery from mixed fill. Reused marble architectural and sculptural fragments, numerous inscriptions, and highquality imported ceramics reflect a well-connected and sophisticated community during the Iron Age and classical periods. Excavations continued in 1995.

Kyaneai. Reports giving the 1992 and 1993 results of this long-term survey are presented by F. Kolb in ArassST 12 (1995) 83-98. For Balboura and Oenoanda, see above, under "Pamphylia, Pisidia."

\section{Caria}

Kaunos. In an effort to rediscover more of the honorific monuments that once stood in the public district near the harbor at Kaunos, Cengiz Iş1k turned in 1994 to the round peristyle building excavated in 1969 beside the harbor stoa. He suggests that this elegant structure of fine marble may be connected with an inscribed entablature block, reused in the later stoa, and mentioning a heroon dedicated by 


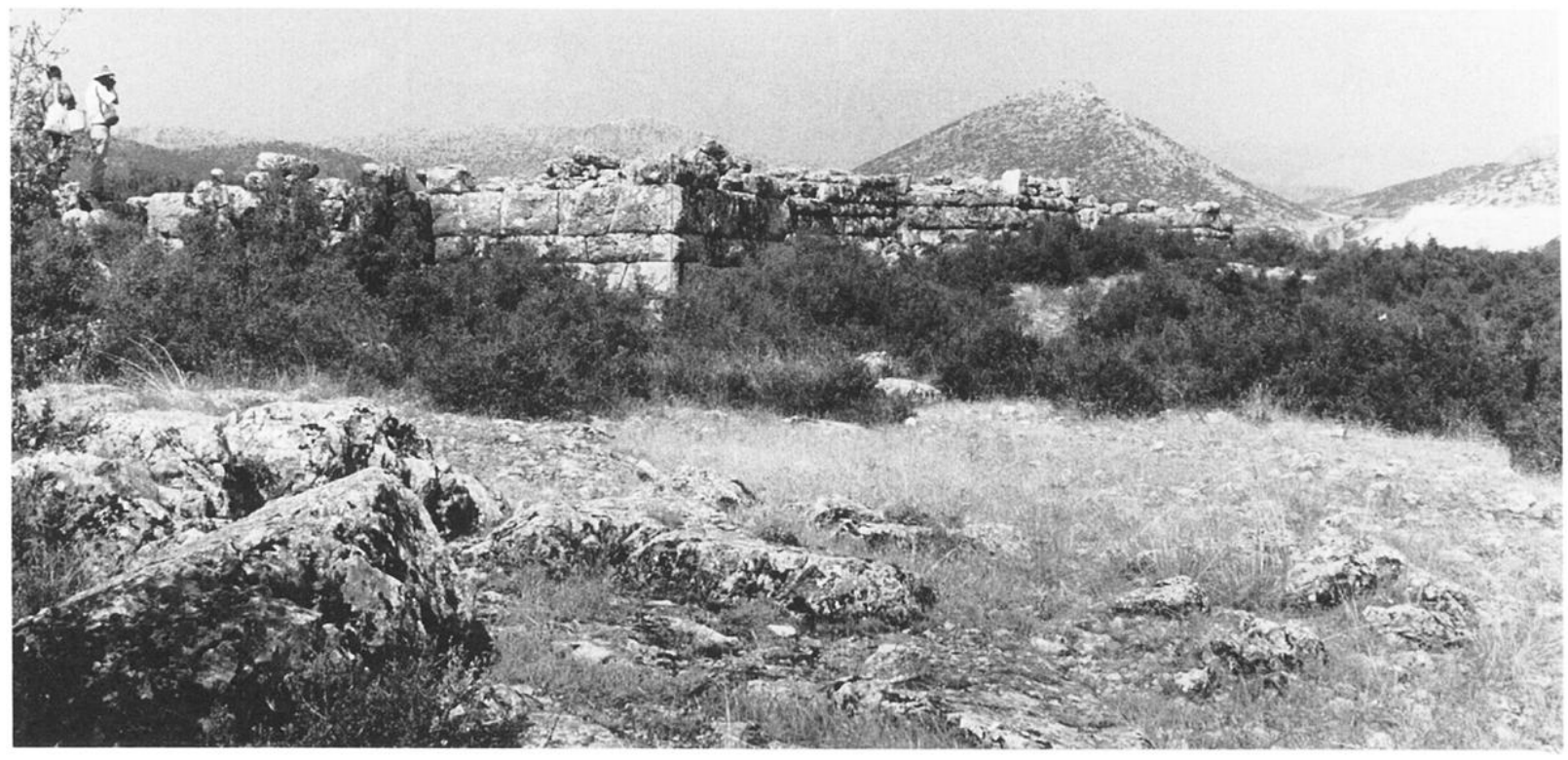

Fig. 33. Kepez Kalesi, Pisidia. Hellenistic city walls. (Courtesy M. Waelkens)

the Kaunians in thanks to the people of Rome. A monolithic inscribed pillar found behind the stoa may also have been moved from a platform adjoining a building further north, where a series of niches and socles would have displayed statues of prominent citizens. Iş1k would place a base for a bronze statue on top of the pillar. For his reconstruction of the Protogenes monument, and other excavations at the site, see KST 15:2 (1994) 325-39 and 16:2 (1995) 319-25. The fountain house in the Harbor Agora is discussed in a final report: C. Işık, Kaunos Arastırmaları II.2: Liman Agorası Ceşme Binası (Ankara 1994).

Burgaz-Datça. The history of this ancient harbor was extended back into the Late Geometric period by Numan Tuna's 1994 excavations in the southeastern sector of the site, beside the modern shoreline. The southwestern trenches exposed more of later Greek and Roman architectural levels from the previous season. A chamber tomb associated with the upper domestic architectural phase (second-third century A.D.) was discovered intact, its stone door still in place. Inside were found 30 individuals, and numerous funerary gifts (lamps, pitchers, small amphoras) placed on a niched shelf that lined the walls. Soundings on the small acropolis indicate severe erosional loss. The first season is reported in KST 16:2 (1995) 283-95.

Knidos. Ramazan Özgan devoted the 1994 season to restoration of the frescoed Hellenistic/Early Roman house from the terrace beside the Aphrodite temple; and to the excavation of more of the small one-room shops or public facilities built along three terraced streets on the promontory overlooking the south harbor. Late black-figure pottery re- covered from a plastered cistern could push their construction date back into the fifth century. For the 1991-1993 seasons, see KST 15:2 (1994) 161-88 and 16:2 (1995) 297-314.

Keramos. The exceptionally well-preserved monuments still visible among the modern houses at Ören, on the north side of the Gökova bay, were recorded in 1993 by Marcello Spanu, whose preliminary report appears in ArassT 12 (1995) 133-44. He suggests that the structure known locally as "Bakicak," and previously identified as a temple, should be understood as an elaborate nymphaeum of perhaps Trajanic date and western (Italian) construction.

Bodrum-Halikarnassos. Poul Pedersen provides interim reports on the 1992 and 1993 seasons, with commentary on the Mausolos palace soundings, in KST 15:2 (1994) 135-47 and 16:2 (1995) 327-34.

Iasos. In addition to continuing salvage excavations in the northeastern necropolis around its prominent Roman mausoleum ("Clock Tower"), and restoring to its original elegance the site's most elaborate funerary monument ("Fish Market") to serve as a museum, Fede Berti and her colleagues reopened excavations in the agora and on the acropolis. Soundings in the agora below the Hadrianic northeastern portico revealed an earlier Doric version with unfluted columns, and an associated pavement with Roman inscriptions and graffiti. To the north of this, fine isodomic masonry from a Hellenistic structure and an associated pavement suggested that the drainage system here was originally installed at the same time, rather than in the Hadrianic period as previously proposed. An opus sectile floor with poly. chrome geometric designs could belong to the Hel- 
lenistic structure, since such floors were attested in Italy by the second century B.C.; but the area was also much reworked, and remained in use into the Byzantine 11th century.

Below the Hellenistic level were family tombs whose burial gifts include late fifth-century B.C. pottery. It is not yet clear whether the tombs should be linked symbolically with the agora, or belong to a period when the area enjoyed a different function, since Iron Age burials were also excavated here in earlier campaigns. Research was also carried out on the acropolis temple. For the 1992 and 1993 seasons, see $K S T$ 15:2 (1994) 125-34 and 16:2 (1995) 335-39. Related regional surveys conducted by Eugenio La Rocca are summarized in AraşST 11 (1994) 169-89.

Labraunda. The marble sculptures from the Hekatomnid sanctuary have been published by Ann C. Gunter, Labraunda. Swedish Excavations and Researches II:5 (Jonsered 1995).

Stratonikeia. Limited excavations were carried out by Yusuf Boysal in 1994. Reports on the 1992 and 1993 campaigns appear in KST 15:2 (1994) 121-23 and 16:2 (1995) 315-17.

Lagina. In a second season directed by Ahmet Tirpan, excavations on the southeastern side of the site outside the propylon of the sanctuary of Hekate uncovered a further stretch of the road leading to Stratonikeia, and bordered with tombs from the sixth century B.C. to the Byzantine period. Numerous inscriptions on the orthostats lining the road as it nears the gate read XOPO $\Sigma$ EONTO $\Sigma$. The Doric stoa that frames the eastern side of the sanctuary was also partially cleared: its columns and entablature collapsed in place when the sanctuary was violently burnt. In the area of the temple proper, enough entablature fragments were recovered to show the work of five separate craftsmen. The season also produced a number of small fragments to supplement the temple frieze now in the Istanbul Archaeological Museum. Other sculptural finds include part of a round altar with a relief showing three dancing women, one holding a lyre, reminiscent of the maiden frieze from the Sagalassos heroon (supra, fig. 30).

Outside the sanctuary and to the east, the sacred pool or circular nymphaeum was excavated to its depth of $1.5 \mathrm{~m}$, still preserving some of its travertine revetments and three of the columns that once stood on its perimeter. Water was piped in from a source to the south. The pool had been repaired on at least two occasions. A still unpublished inscription from here, found one century ago and reused in a nearby house, is said to relate to the pool's construction.

Nysa. Vedat İdil has spent several seasons excavating and restoring the town where Strabo was educated, so that many of its Roman public buildings are now reemerging from the midst of olive groves. These activities have alerted thieves to the site's interest. In 1994, theater reliefs were removed with heavy equipment. It is fortunate that they were then abandoned along the Ödemiş highway, and eventually recovered. A progress report for 1992 can be found in KST 15:2 (1994) 115-20.

Aphrodisias. The program of urban study, mapping, inventory, restoration, and regional survey conducted by R.R.R. Smith and C. Ratté in 1994 maintained the energetic standards of the previous season, which had already succeeded in transforming our perception of this city's configuration and its relation to the surrounding landscape.

Excavations again concentrated on establishing more clearly the city's grid. The area behind (north of) the bouleuterion was cleared to document the shift in orientation from the Aphrodite temple to the new street plan of the Late Hellenistic (first century B.C.) period. It was found that the transition was achieved at the northern row of chambers, whose front and back facades run parallel with the two different alignments. A sideline of this study was the reexamination of the Late Antique sculptor's workshop excavated in the 1960 s, whose many practice pieces have recently been inventoried. The northsouth axial street of the new urban layout was also discovered in 1994, in a sounding $30 \mathrm{~m}$ north of the tetrapylon (later incorporated into the Byzantine triple-apsed or Triconch church), where the eastwest axial street was traced in 1993. Aphrodisias has thus recovered the two major streets that determined its alignment. A further segment of the northern street leading to the southern agora was found at the western end of the Great Basilica. A Hadrianic inscription referring to taxes on nails was reused here as a paving stone, placed (deliberately?) face up. A blue marble base for an equestrian monument can be associated with a blue marble horse found here in the 1970s.

Mapping extended in 1994 to the stadium, a plan of which was drawn for the first time. Inscriptions on the seats record the names of guild members, city officials, and visitors from nearby towns. The stadium's eastern end was transformed into an amphitheater in Late Antique times, when an arcade was erected along the top. The inventory of spolia, statues and their bases, and sarcophagi added several hundred more numbers to the collection, with sarcophagi accounting for over 500 of the total. These include 12 newly excavated by the local museum; one of the sarcophagi illustrates two men on either side of a furnace, perhaps glassblowers or smiths. All of the sculpture previously kept in the excavation compound was moved into a secure, newly designed depot 
that will also function as a workshop for marble conservation. The need for such protection had been confirmed by the recent theft of a head from the Sebasteion reliefs; it was recovered (from a dealer) and restored to its proper place at the end of the season.

As part of the ongoing regional survey project, the circuit walls, inner redoubt, and stadium of Antioch-on-the-Meander were mapped. A full preliminary report of the 1994 campaign appears in AJA 100 (1996) 5-33; the 1993 season is published in AJA 99 (1995) 33-58, and KST 16:2 (1995) 191-206. R.R.R. Smith presents the corrected reconstruction of the Zoilos monument in Aphrodisias I: The Monument of C. Julius Zoilos (Mainz 1993).

Herakleia am Latmos. In 1994 Anneliese PeschlowBindokat continued to conduct her long-term survey project in the environs of Herakleia, in recent seasons tracing the routes that connected the city to sanctuaries and forts in the Bessparmak/Mt. Latmos range and ultimately across to the northeast and northwest. These sites, like Herakleia, owe their remarkable preservation to their remoteness; and their fine masonry, fortifications, and temples to Hekatomnid ambitions. They also succeeded in preserving local Carian cults alive under a Hellenizing veneer, as at Bağarcık high above Herakleia to the northeast. For 1993, see AraşST 12 (1995) 123-31; a 1994 report is published in $A A 1995$ (forthcoming).

Prehistoric cave paintings newly discovered in the Latmos area are discussed above, under "Palaeolithic."

Harpasa. The long-term survey and epigraphical project conducted by Enver Varinlioğlu and French colleague P. Debord to document settlement patterns in Caria focused its attention in 1994 on Harpasa (modern Esenköy), south of Nazilli on the Akçay (Harpasus) River. Soundings demonstrate that the Hellenistic town was built on an earlier foundation, going back at least to the sixth century B.C. It prospered until Byzantine times, when the site contracted in size and functioned primarily as a fortress. The Ottoman period revived its economic importance as a market center. For earlier survey results, see ArassT 11 (1994) 199-204 and 12 (1995) 25-27, and Asia Minor Studien 8 (1992) 17-22.

\section{Ionia}

Miletos. The 1994 season was spent in evaluating past results, and assessing the directions in which new research interests will lead the excavation project in the coming years. A major decision involved reviving the Bronze Age investigations, which are summarized above (see under "Chalcolithic and Bronze Age: Western and Coastal Anatolia”). An- other, more general shift in focus has led to increased efforts at placing the site within its diachronic regional and environmental context. Volkmar von Graeve, Ruhr-Universität Bochum, kindly reports:

"Interdisciplinary projects took precedence in 1994 over excavation, which - beyond the Bronze Age program directed by W.D. Niemeier - was limited to salvage work in the Aphrodite sanctuary. Archaeobotanical and archaeofaunal projects, begun in 1992, are investigating the resources available to Milesians in the Archaic and later periods. This study will combine forces with the archaeological survey, now in its fourth year, of the $200 \cdot \mathrm{km}^{2}$ area around the site to discover the ecological setting that made it prosper and the extent to which it was exploited. In the same spirit of inquiry, the Roman water supply system is being retraced via its canals and reservoirs.

"Geophysical surveys of the site have also produced subsurface information about the city enclosure wall's extension toward and around the Archaic residential district of Kalabaktepe. The results, suggesting a larger circuit than previously thought, will be tested with soundings in 1995. Similar efforts in the Bay of Lions have identified another large structure near the harbor.

"A major reassessment of the location of Milesian cemeteries will now be required as a result of new research in the Kazartepe necropolis, which was always assumed to have served during the Archaic period. Clearing of the chamber tombs and associated structures in preparation for their publication has shown that only one honorific monument can be dated this early, and must have commemorated an exceptional person. Although Miletos has now acquired a fine new monument, the Archaic necropolis will nevertheless need to be sought elsewhere.

"Conservation continued in the theater, the Baths of Faustina, and the Hellenistic Heroon I. In addition, the cooperative project with the State Waterworks Department to control the site's annual flooding is making good progress. A more discouraging challenge is how to prevent illegal excavations, such as occurred during the winter in the Aphrodite sanctuary. Such incidents underscore the difficulties involved in protecting even the most visible sites from looting."

The 1992 and 1993 seasons are presented in KST 15:2 (1994) 83-99 and 16:1 (1995) 405-17; a detailed summary of the 1988-1993 results is published by V. von Graeve et al., $A A$ 1995, 195-333.

Didyma. Klaus Tuchelt and his team pursued the project's current survey of the Sacred Road leading from the sanctuary of Apollo to Miletos. A small spring and nearby stream marked the location of 
an Archaic nymphaeum, the source for a seventhcentury B.C. headless statue of a woman holding a bird. In mid-Imperial times, a bath building was constructed there. The area was later used for burials.

Restoration work continued in the Apollo temple, and $80 \mathrm{~m}$ to the north, in the village mosque, where a polygonal stone pavement and a reused Hellenistic architrave were revealed. A platform for an altar has been discovered between the temple and the mosque, beside the sacred road. Brief summaries of the 1992 and 1993 seasons appear in KST 15:2 (1994) 69-82 and 16:2 (1995) 341-43. A full report on the Sacred Road and its monuments is in preparation: $K$. Tuchelt et al., Didyma III:1: Ein Kultbezirk an der Heiligen Strasse von Milet nach Didyma.

Priene. Publication research on the Agora and the Lower Gymnasium, regional survey, and restoration of the theater were again carried out under Wölf Koenigs's direction in 1994. For a progress report, see ArassT 12 (1995) 145-66, and AA 1995 (forthcoming).

Magnesia ad Meandrum. Orhan Bingöl's efforts to free the Artemis sanctuary and surrounding structures from a century of alluvium turned in 1994 to the temple proper, where he suggests that the east entablature is lying complete except for its frieze (now in the Louvre in Paris). The results of the 1992 and 1993 seasons can be found in KST 15:2 (1994) 41-52 and 16:2 (1995) 43-56.

Metropolis/Torball. The three excavation areas of previous seasons were continued in 1994 by Recep Meriç. A second stratigraphic sounding on the acropolis, where the earliest, Iron Age settlement was located, has pushed occupation back to the Subgeometric period, as well as confirmed that the acropolis was abandoned from the fifth century B.C. until the Early Hellenistic period. Excavation of the Hellenistic stoa at the base of the acropolis was completed; the initial building is still to be dated in the early third century B.C., with Roman and Byzantine modifications. In the exceptionally well preserved theater, the stage building, intact even to its marble floor, was freed of $6 \mathrm{~m}$ of erosional fill. That the theater was entirely buried by the fourth century A.D. can now be demonstrated by the products of a glass workshop, installed on top of the erosion level above the left parados.

Ephesos. The 99th excavation season at Ephesos again expanded its team and its ambitions, with stratigraphic research, conservation, and publication projects under the direction of S. Karwiese. The ongoing sounding at the northwestern end of the Artemision came down on a Mycenaean building level with wall foundations built of unworked fieldstones. It seems to underlie an eighth/seventh century B.C. level without intervening deposits; whether the hiatus is indeed reflecting a broader pattern, or merely restricted to this area, cannot be determined on the present evidence. In the agora, at least, the earliest occupation began in the seventh century B.C., as Ionian Geometric pottery from the base of deep soundings has repeatedly indicated. Stratigraphic research in the agora has now been concluded, and the ceramic sequence is being prepared for publication.

Other projects of previous seasons continued: on the Hellenistic-Late Roman cemetery outside the Damianos stoa; on the second-century A.D. Olympeion and South Stoa, which now appear to be contemporary; at the Church of St. Mary, which reused stone architectural elements from the Olympeion in its apse and earliest flooring, now to be dated during the fifth century A.D. but before the Council of A.D. 431; on the stadium, where a marble portico of Hellenistic date (part of Lysimachos's circuit wall?) may have given access to a formal road leading to the Artemision; and on the water supply to the villas on the southern slope and elsewhere, a system that functioned until the Arab invasions. Conservation and large-scale restoration projects at the lower end of the main street involved reerecting the portal and colonnade of the Temple of Hadrian; and wrestling with the fig tree that had grown around the Hellenistic heroon or Androcleon, a monument dedicated to the founder's cult and already repaired on several occasions in antiquity. The theater and selected Roman chamber tombs are also being restored. For a summary of the 1993 campaign, see KST 16:1 (1995) 419-24. The Mycenaean finds from the Artemision sounding are discussed by A. Blakolmer in ÖJh 63 (1994) 28-39.

Claros. Juliette de la Genière's program of the past six seasons to document the history of the oracular sanctuary of Apollo and the adjacent Artemis temple, and to restore their final and most flamboyant Hellenistic-Roman phase, proceeded in 1994 with more deep soundings and a large team of conservators. Soundings to the southeast of the Apollo temple have followed the continuation of four parallel rows of hecatombs (second century B.C.) that attest to the scale of sacrificial activities there. The possibility that they overlay earlier installations, as suggested by reused blocks of similar type, was confirmed by the discovery of some of these predecessors in situ. Large numbers of molded votive terracottas, representing and perhaps offered by children and young girls as at Brauron, give the associated hecatombs an Archaic date. Despite the problems of excavating below the water table and deep silting, the sequence of Artemis 
temples has now been defined as four Archaic versions and two Hellenistic ones. The soundings produced a fine head from an Archaic sculpture, a fibula, and Attic Protogeometric sherds that could herald a foundation for the Artemis cult as early as the 10th century B.C. The sanctuary's abrupt collapse in the later Roman period can be gauged by the dramatic tumble of honorary monuments to the south of the Apollo temple, where excavations continued removing the especially thick silt.

In conjunction with the restoration of the colossal sculptural group representing Claros's sacred family-Apollo, Artemis, and Leto - a reproduction has been made by Lafarge-Coppée, whose previous experience with the Khorsabad sculptures prepared them for the task of casting sculpture on this scale (the Artemis leg alone weighs 7 tons!). The group was originally placed in the cella of the Apollo temple during the reign of the emperor Commodus. The 8-m-high honorific column of Sextus Apolleius is being reerected in its findspot on the sacred road. For the 1992-1993 interim reports, see KST 15:2 (1994) 53-68 and 16:2 (1995) 39-42.

Teos. In 1993 Numan Tuna resumed D. Mustafa Uz's project with a survey, and continued efforts to save the site from encroaching constructions. For an assessment, see ArassT 12 (1995) 167-76.

Klazomenai. Local industries of the Archaic period were further documented during the 1994 campaign at Klazomenai, as Güven Bakır and Yaşar Ersoy, Ege University, Izmir, kindly report:

"The season's work concentrated on two different areas: on the southern acropolis slope along the Yıldıztepe necropolis road, where an industrial district occupied the outskirts of the city; and in the western sector of the city proper, in a complex devoted to the production of olive oil. The industrial district, consisting of two main phases and their sublevels, began its activities in the second quarter of the sixth century with ceramic production. Kilns associated with quantities of Wild Goat-style pottery were found directly on bedrock, although a few Late Geometric and Subgeometric sherds in the same deposit may point to an earlier presence in the area too. In the second half of the century, when a series of workshops was constructed here as a second building phase, the pottery industry diversified to include bone-carving and iron metallurgy. Significant num. bers of cooking vessels from both levels suggest that the artisans working here also lived in their shops.

"The olive oil factory first investigated in 1993 was excavated further toward the north, where the exis. tence of two phases became evident. Both are dated by ceramics to the second half of the sixth century, but before the Persian destruction of 530 B.C. The ancient olive oil industry required two mills, hot water, and lime, thus both processing and storage facilities. All of its elements can be documented here, including a water supply from channels that bordered the road beside the factory. While the rooms themselves were built with stone walls, the specialized installations were cut into bedrock: these pits and vats, in shapes appropriate to their functions, would have been used for crushing the fruit, extracting the oil, and collecting it (fig. 34). The large plastered pits with a central circular depression were housings for the mills, whose two parts were held together with a pivot. In the northern extension of the complex, intact pithoi set into the floors, their rims flush with the pavement, were probably used to store the oil. They were sealed off when the floors were repaved in the complex's second phase (fig. 35) probably not long after the initial setup. Finally, the amphoras found in significant numbers in these deposits must have served as portable containers for the finished product."

Bayrakl1-Old Smyrna. Excavations directed in 1994 by Meral Akurgal continued in the fourth century B.C. western residential district, where two more streets faced with tightly packed buildings were uncovered. Among the houses was a workshop filled with molds for terracotta figurines. North of the Athena temple, the Cyclopean enclosure wall was followed further toward the east. Outside it, a corbeled fountain house dating to the late seventh century B.C. was excavated completely so that its structural aspects and relation to a nearby spring could be studied before beginning restoration work. The 2.5-m.high fountain house was built of rectangular blocks on basalt foundations, abutting the different masonry of the fortifications. Behind it, a conduit covered with large slabs led to the spring proper, which was channeled via a deep square shaft. Similar systems are known from Miletos and Syros. The 1993 season is presented in KST 15:2 (1994) 37-40. Attic black-figure pottery from Bayraklı and other western Aegean sites is discussed by Y. Tuna-Norling in AraşST 11 (1994) 437-51.

Lydia

Sardis. The Archaic and Classical lower city's massive fortification wall, Late Roman and Byzantine housing, conservation, publication research, and potential sources for Sardis's limestone and marble claimed the careful attention of the Harvard-Cornell Expedition during the 1994 season. C.H. Greenewalt, jr., University of California, Berkeley, graciously reports: 


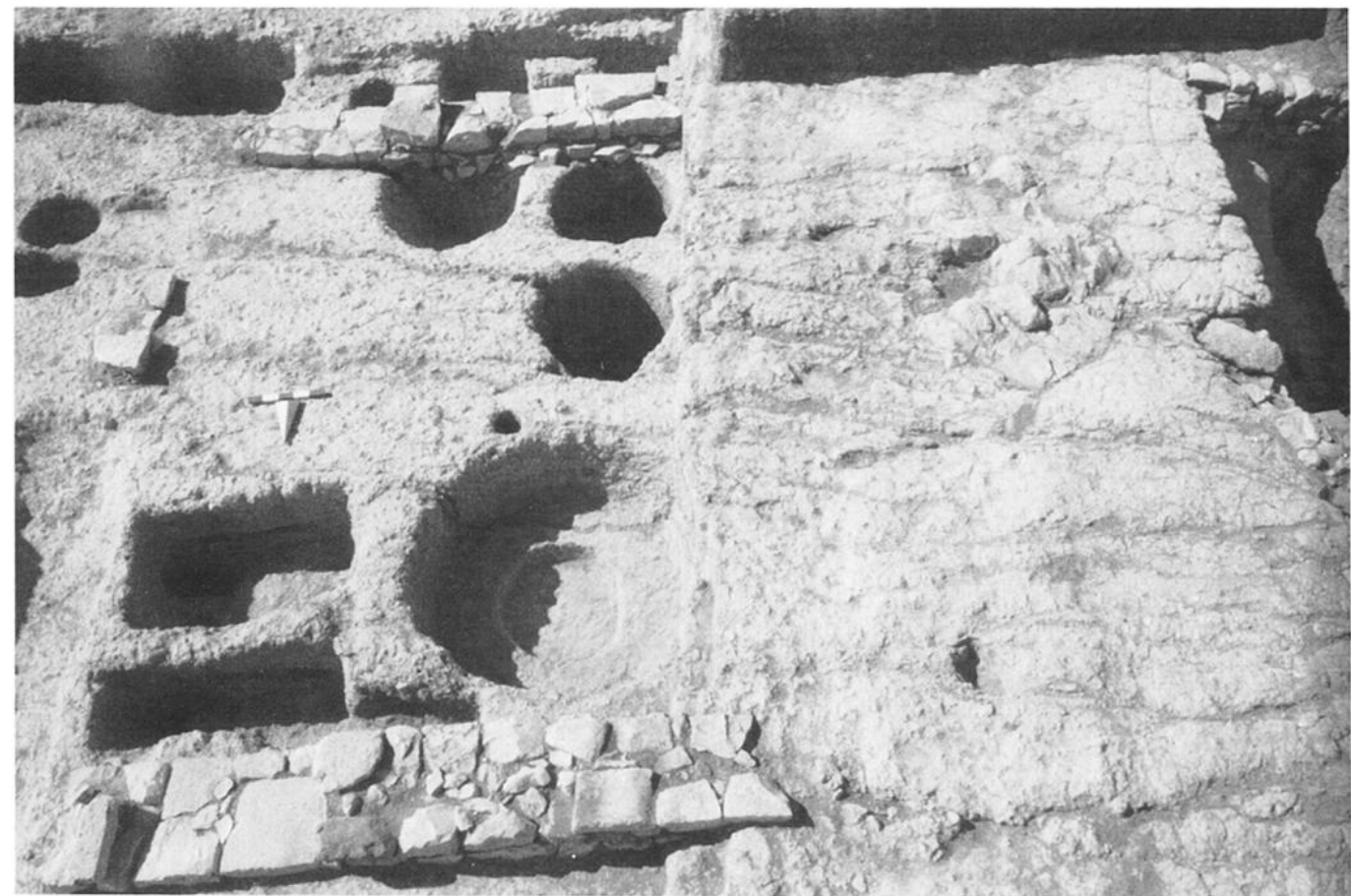

Fig. 34. Klazomenai. Olive oil complex, with installations cut into bedrock. (Courtesy G. Bakır and Y. Ersoy)

"Excavation again focused on the area at the northwestern foot of the Acropolis (sectors MMS/N, MMS, MMS/S), where a fortified line of defense existed for about 300 years, from the seventh to the fourth cen. tury B.C. Two major phases can be distinguished in the $150 \cdot \mathrm{m}$ stretch that has been exposed. The earlier includes, at the northern end, a gate whose foundation trench contained sherds (Middle Wild Goat

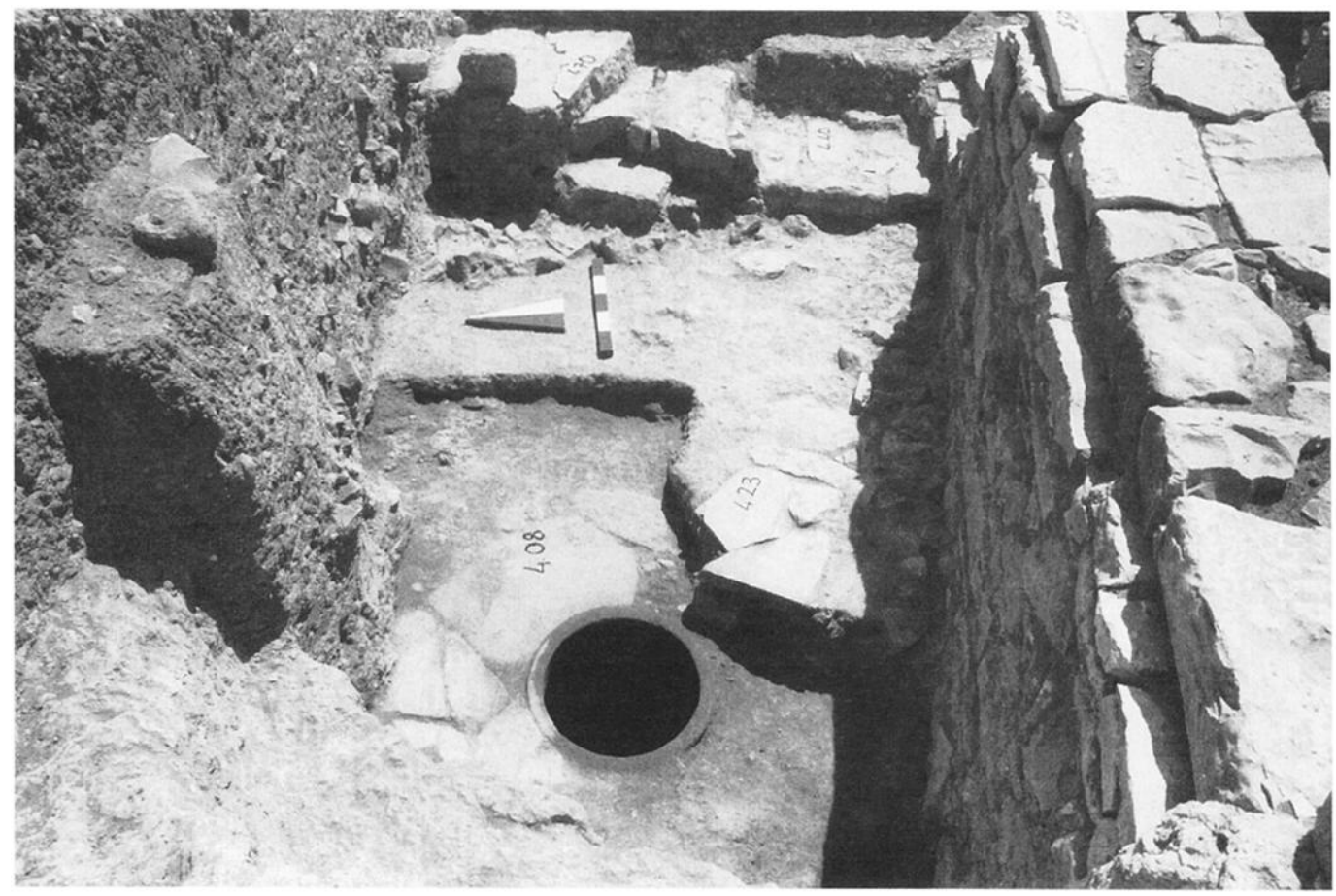

Fig. 35. Klazomenai. Olive oil complex: pithos belonging to original flooring, with reflooring pavement visible. (Courtesy G. Bakır and Y. Ersoy) 
Style and Corinthian or Orientalizing East Greek wares) confirming its construction in the third quarter of the seventh century B.C. The gate itself was built over two cobbled roads that antedate the fortifications. After the Persian destruction in the midsixth century and the city's conversion into a satrapal capital, the gate was blocked and traffic diverted from this perennial east-west thoroughfare to some other route. The second phase, following shortly upon Sardis's rehabilitation, reused the earlier fortifications as a rampart to support and elevate a 5-m-thick stone wall built on top, while leaving exposed at least one part of the earlier version's facade. A mid-sixth century occupation surface at the foot of this facade produced more iron objects, bringing to over 300 items the Archaic iron assemblage recovered from this area since 1992. The defensive system continued to enclose and protect the lower city into the fourth century B.C.

"This area was occupied during the following centuries, but architectural features remained modest until the Late Roman period, when the thorough. fare took on a monumental character as an $18 \cdot \mathrm{m}$ wide avenue flanked with colonnaded porticoes. The sector excavated in 1994 (MMS/N) contained a paved walkway perpendicular to the south portico and run. ning south, perhaps to one of the neighboring insulae. Portico and walkway were substantially built of spolia, such as the torso of a draped figure whose unfinished back destined this statue for a more dig. nified initial setting in a niche or against a wall. And although the residents of Sardis during this period appear to have respected their predecessors' constructions only as a ready source of building material, their own houses were carefully preserved and re. stored well into Middle Byzantine times. When, in the course of the season, we dismantled these houses for access to the underlying Archaic strata, we found that their walls consisted of stratified courses whose mortar contained pottery dating, in the uppermost layers, to no earlier than the eighth or ninth century A.D. The homogeneous external appearance of these walls would have suggested a single phase of construction, instead of repairs actually spanning half a millennium.

"Conservation efforts focused on the pottery and metal finds from the Lydian residential unit excavated in 1993, a chronologically precious subassemblage of conventional Lydian and East Greek vessels that predate the Persian destruction; painted funeral klinai supports recovered by the Manisa Museum from an Archaic tumulus chamber at Bin Tepe; painted wall plaster from the Late Roman housing in MMS; sections of the earlier fortification; and the unfinished crepis wall inside Karnıyarık Tepe. Research projects on the EB cemeteries excavated 30 years ago beside the Gygean lake, Hellenistic relief ware, Lydian pottery, and Roman terracotta water conduits will lead to publications and doctoral dissertations. Fikret K. Yegül continued his architectural recording of the Artemis temple.

"A survey for the stone sources that supplied Archaic Sardis's contractors identified several limestone quarries on the Bin Tepe ridge, and marble quarries (one inscribed with XOPO , or "boundary") to the south and southeast of Sardis. Sampling of the marble used in the Tomb of Alyattes and Karnıyarık Tepe, however, suggests in preliminary analysis that the best match is not with local types, but with marble from the Kuşini quarries near Ephesos."

Reports on the 1992 and 1993 seasons have been published in KST 15:2 (1994) 101-13 and 16:1 (1995) 393-404. C. Ratté discusses the Archaic architectural terracottas in Hesperia 63 (1994) 361-90; on this topic, see too E. Hostetter, Lydian Architectural Terracottas (Atlanta 1994).

\section{Aeolis-Mysia}

Pergamon. The four-month 1994 season at Pergamon concentrated its research and conservation efforts on the acropolis's two most salient monuments: the Altar of Zeus and the Trajaneum, with outright excavation limited to soundings tracing the city's system of streets. Wolfgang Radt, Deutsches Archäologisches Institut, Istanbul, kindly discusses and illustrates the results:

"It seemed timely to investigate once again the Pergamon Altar, which has recently been the subject of renewed discussions concerning its date and details of reconstruction. To this end, the still intact foundations were cleaned in order to test the accuracy of their plan; several of their compartments were excavated for chronological indicators, and to reexamine the apsidal building that underlies them; and clues to the original placement of the marble superstructure were carefully studied.

"The altar's foundations consisted of a $4.5 \cdot \mathrm{m} \cdot \mathrm{high}$ structural core designed as a casemate system, with rectangular compartments all of uniform size except in the narrower outer row (fig. 36). This core was then entirely concealed with marble revetments; it should be noted, however, that the long-standing reconstruction of the northeastern corner (see below, fig. 38) was put together from blocks that were not found in situ. Previous excavations by Humann, von Conze, and, in 1961, by J. Schäfer had focused on the central portion of the foundations, and emptied three of the compartments. This year, in addition 


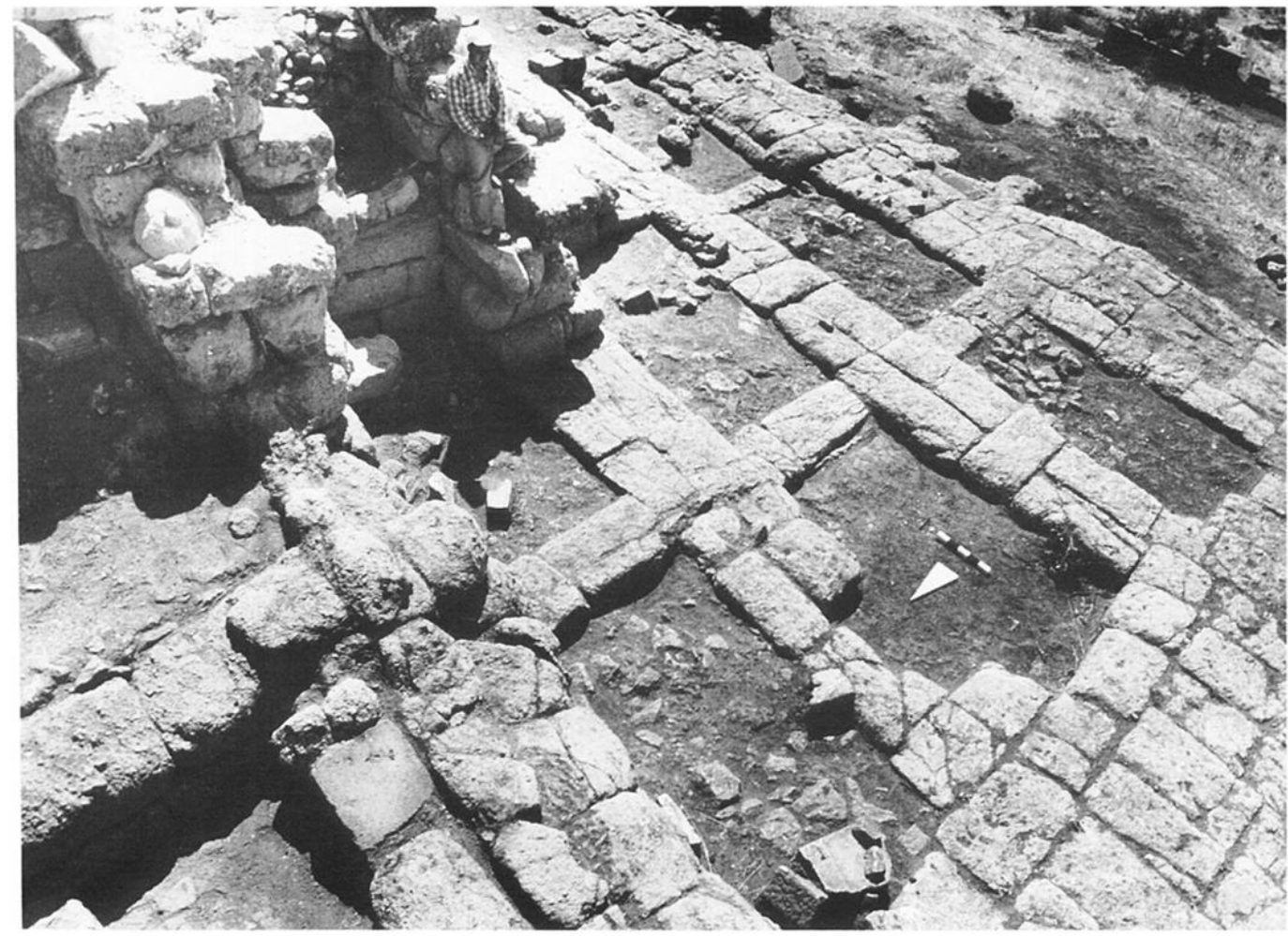

Fig. 36. Pergamon. Altar of Zeus: foundations in northwestern zone. (Photo E. Steiner)

to cleaning the top and the perimeter, 10 more compartments were cleared down to bedrock and the other three reexamined. The painstaking method used in their construction can now be understood. Their walls were built of large tufa blocks, which were laid down only one or two courses at a time until the same level inside the compartments could be obtained, tightly packing them with andesite rubble and a covering layer of earth (fig. 37). The packing stones included squared and polygonal blocks from dismantled Hellenistic buildings (such as the underlying apsidal one), as well as small and very large rough fragments. This technique ensured that the monument would resist settling and even earthquake damage.

"Efforts to learn more about the plan and nature of the underlying apsidal structure were not fully rewarded, in large part because the preparations for the later altar involved a meticulous clearing of the area. No trace of it could be discovered beyond its eastern apse, despite a careful search at the base of the compartments bordering its presumed northern, southern, and western walls. To Schäfer's previous study, however, a few details can now be added. The outer face of the apse preserved some of its orig. inal red plaster coating, while the interior face was plastered in white. Shallow drainage channels were cut into the bedrock near the wall, but appear un- related to it. They must have belonged to the Early Hellenistic houses that extended to the south of the Altar, and either preceded or were coterminous with the apsidal building itself. No closer date within the Early Hellenistic period could be assigned to the apsidal building as a result of this new study.

"A considerable amount of pottery was recovered from the soil layers in the compartment fill, and there

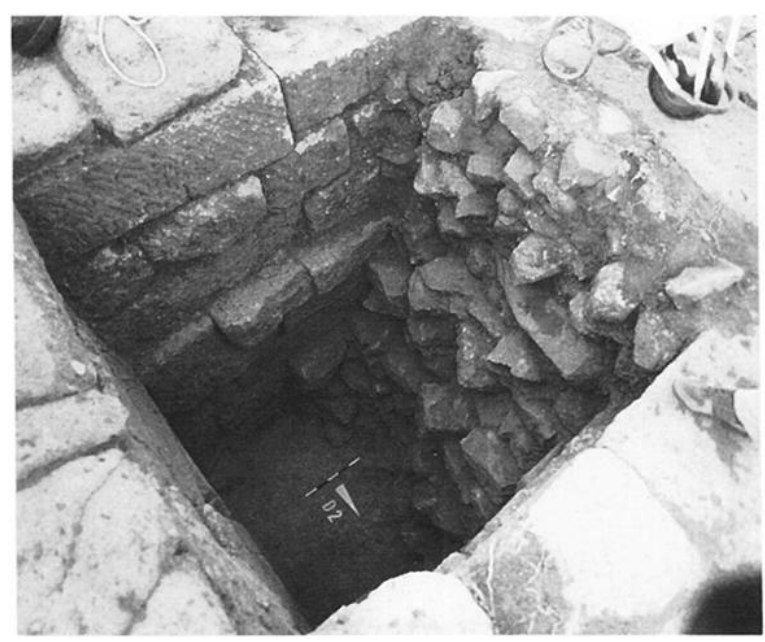

Fig. 37. Pergamon. Altar of Zeus: compartment D2, with Hellenistic rubble packing still in place in its western half. (Photo E. Steiner) 


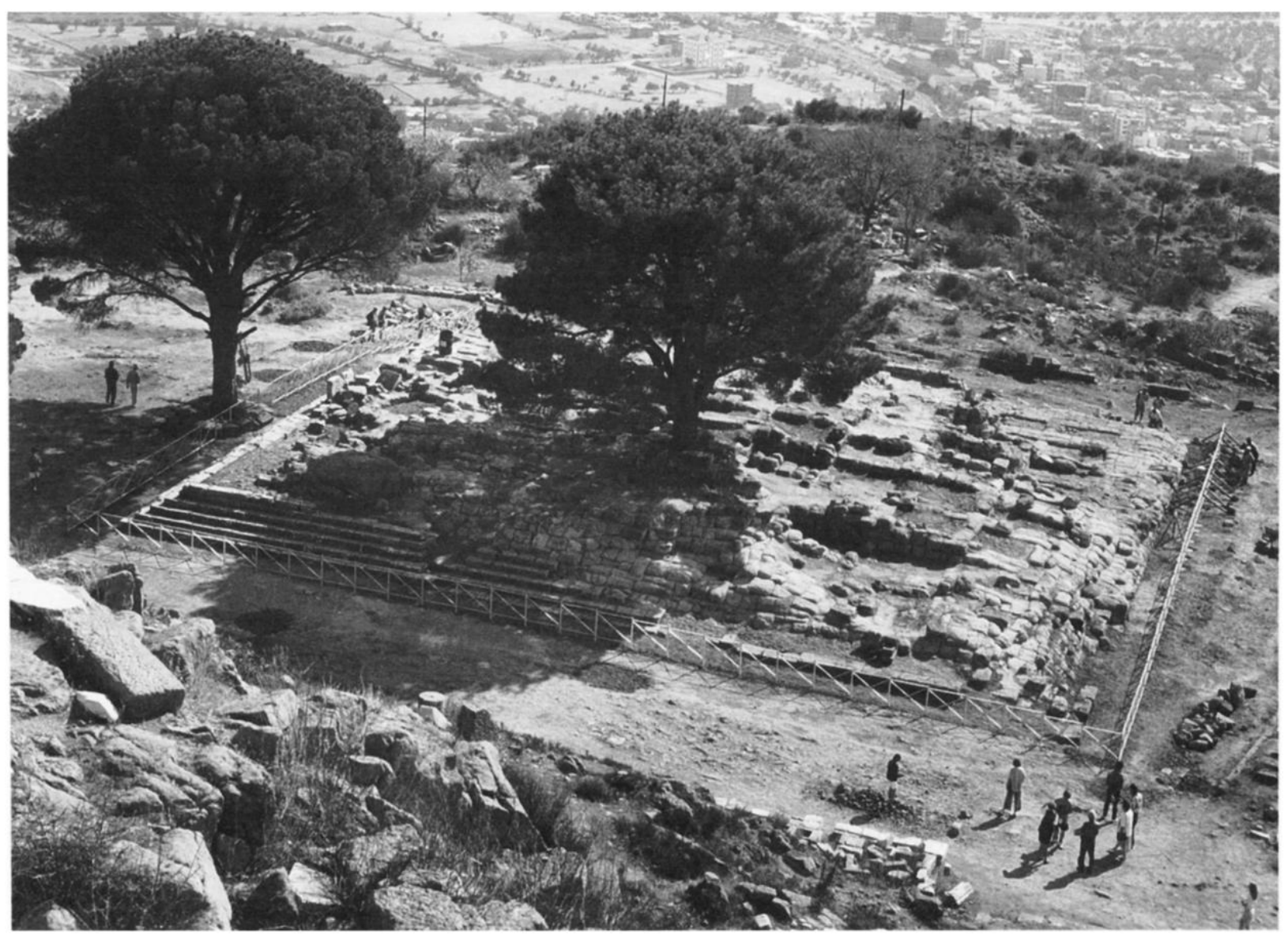

Fig. 38. Pergamon. Altar of Zeus, from the north, at the close of the 1994 season. (Photo E. Steiner)

was no difficulty in distinguishing the Hellenistic deposits from those previously excavated, or others disturbed by the Byzantine housing that overlay this area. The original deposits provide an excellent review of the entire range of local ceramic production in both fine and coarse wares, from a context sealed in the first part of the second century B.C. Although this ceramic assemblage can be considered a reliable general indicator for the Altar's date of construction, unfortunately neither it nor the few identifiable coins from the fill can narrow down its date more closely within the 185-160 B.C. range. The season's finds and those of Schäfer's investigations will be presented in a forthcoming publication of the entire monument, together with a new plan of the foundations, and a detailed study of the marble superstructure - for which the season recovered a number of small fragments. The compartments were filled in at the end of the season, and the foundations enclosed in a fence to end 'tourist erosion' (fig. 38).

"Soundings to determine Pergamon's urban lay. out by locating its network of streets continued this year in the unexcavated northeastern residential district on the steep slope southeast of the Upper Agora and the Altar. Here a stepped street, bordered by deep drainage channels, was newly discovered and followed for some length. The carefully cut stone slabs that paved its steps and covered the drains were often incised with the Greek letter X (fig. 39), an interesting contrast to the $\mathrm{E}$ found on the western streets. The street was laid out on a sharp diagonal course (northwest-southeast) at odds with the previously recorded orthogonal axes, and thus requires a reassessment of the criteria directing the Hellenistic planners.

"The 15-year project headed by K. Nohlen to restore the Trajaneum was successfully completed with two concluding rituals: the placement of trilingual explanatory panels outside the entrance; and a celebratory banquet in the precinct for everyone who participated in this undertaking. Conservation of the painted stuccoes from the Masked Mosaic Room in Building $\mathrm{Z}$ also made good progress."

Reports relating to the 1992-1993 seasons can now be found in KST 15:1 (1994) 563-90 and 16:2 (1995) 1-26. For 1994, see $A A 1995,575-96$, with a full bibliography of recent Pergamene studies.

Phocaea. Ömer Özyiğit conducted salvage inves- 


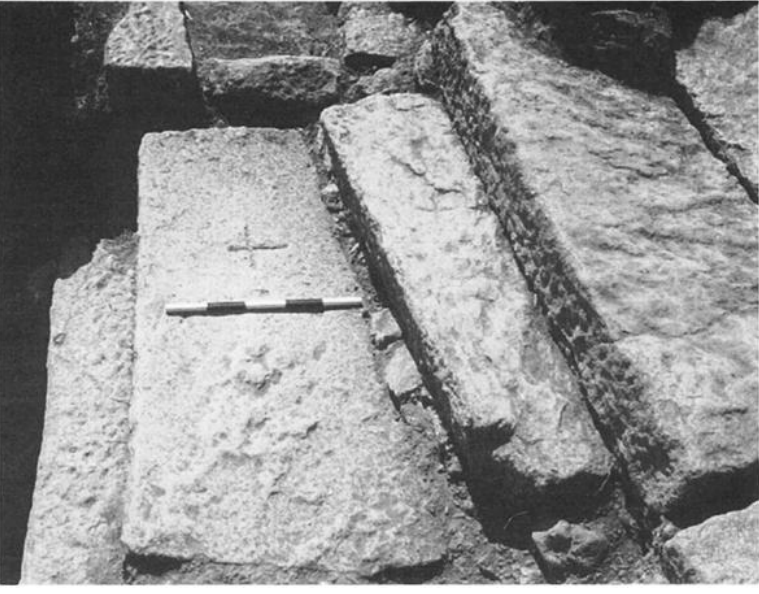

Fig. 39. Pergamon. Northeastern residential district: pavement slab with incised Greek letter X. (Photo E. Steiner)

tigations both above ground and under water in his efforts to record Foça's past before it is eradicated by the city's uncontrolled growth. Research in the poorly preserved Cybele sanctuary, whose foundations were cut into bedrock, uncovered Archaic walling of the sanctuary's first phase, and three rebuildings (the most recent, a Genoese reuse). Archaic terracottas and tufa plaques showing the goddess in an oikos resemble representations of Cybele found in Marseilles, a Phocaean colony [and at later Troysee below under "Troad"]. The Hellenistic tumulus on Maltepe, and the nearby Archaic fortification wall, excavated in previous seasons, were also studied and restored. The rubble used to construct the tumulus contains a wide range of Hellenistic pottery and figurine wasters, clearly from a workshop's dump. They would suggest an active local industry manufacturing even such types as West Slope ware.

The municipality's callousness toward ancient monuments is well illustrated by the opening in the Aphrodite sanctuary of a tea garden, which involved damaging the Ottoman tower that overlooks it; and by an incident involving a marble replica of a Cybele plaque, set up by Özyiğit beside the sanctuary's spring, which was vandalized within 10 days of installation.

For the 1992 and 1993 reports with poignant photographs of these tensions, see KST 15:2 (1994) 11-36 and 16:1 (1995) 425-54; a study of the fortifications has been published in REA 96 (1994) 1-34.

Kyme. Research projects of previous seasons were pursued in 1994 by Sebastiana Lagona and her collaborators in the harbor, the theater, the Hellenistic Isis sanctuary on the north hill, and in the central Byzantine and Roman residential district. Neolithic and $\mathrm{EB}$ pottery has been recovered in mixed contexts.
Interim reports appear in KST 15:2 (1994) 1-9 and 16:2 (1995) 27-37.

Troad

Troy. The project of 1994 focusing on the postBronze Age monumentalized the scale of the Hellenistic sanctuary, discovered Archaic architectural remains for the first time, and began to close the gap between the Bronze and Iron Age phases. C. Brian Rose, University of Cincinnati, kindly reports on his team's progress:

"The excavation area north of the Upper Sanctuary was continued for a third season and expanded, in order to uncover broader plans for the Hellenistic South Building and the North Building's predecessors (fig. 40); and extended into Blegen's Upper and Lower Sanctuaries to recover earlier phases in this precinct. The South Building, with its 3-m-deep foundations of regular marl ashlars, was an enormous building that would have dwarfed every other structure in the area. The $20 \cdot \mathrm{m}$ length of exterior walling uncovered by the close of the season represents only a fraction of the original size. Although the superstructure of limestone blocks has been essentially robbed out, even its few remaining elements highlight the importance of this second-century B.C. architectural commission, now to be understood as an enclosed plan rather than a stoa or portico. It coexisted with the nearby North Building, which was set on a higher terrace formed by the remains of two earlier Hellenistic structures. An iron double ax and an Archaizing gilded bronze sphinx found in 1993 in association with the North Building can now be linked with the symbols of Tenedos and Gergis that appear on their coinage. They may represent gifts from members of the Troad koinon to their capital's sanctuary. Finally, traces of another large Early Hellenistic structure with pebble mosaics and fragmentary wall paintings showing architectonic designs were recovered in a new trench between this area and the Upper Sanctuary - the first evidence linking the two areas architecturally during this time.

"For the earlier stages in this sacred precinct, the Classical phase is so far too badly disturbed by stone robbing and pitting to allow any suggestions. But monuments of the Archaic period are appearing for the first time. Under the porch of the North Build ing, the corner of a building and a column base still in situ were exposed, certainly part of a structure with an interior colonnade. An Aeolic capital in later fill probably belonged to the same building, whose stratigraphic situation would date it to the sixth century B.C. It appears to have had a short duration, since it was sealed off by Early Classical debris. This 


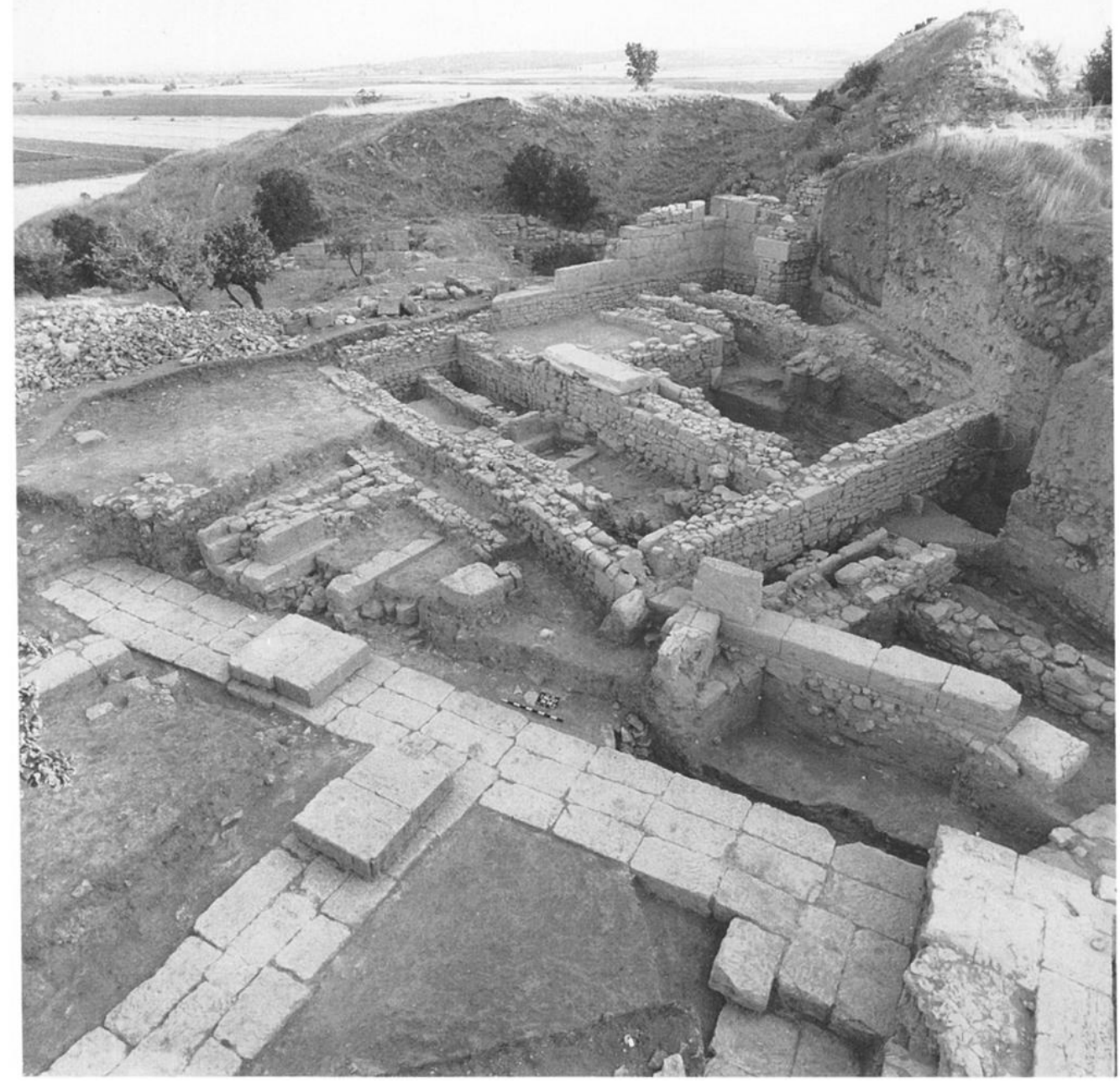

Fig. 40. Troy. The North and South Buildings (second century B.C.), north of the Upper Sanctuary, looking north. (Courtesy C.B. Rose)

monument, a boundary wall to its south, and another potential structure beyond it, were probably contemporary with the two Archaic altars excavated by Blegen in the Upper and Lower Sanctuaries.

"Previously unexcavated deposits in the Lower Sanctuary were investigated in 1994, with results that both confirmed and enlarged Blegen's assessment. Quantities of Orientalizing and Archaic ceramic imports were again recovered here, as well as a variety of votive offerings (notably a faience scarab, two "spectacle" fibulae, and a terracotta figurine). The altar remained in use until the Early Hellenistic period, when it was replaced by a new one at the same time as the Hellenistic mosaic building was founded. Throughout the sanctuaries' history, the two were kept separate from each other by enclosure walls, and distinguished by the different orientations of the altars. Even in the Hellenistic period, when the altars were aligned, the two enclosures remained in. dependent and were equipped with separate wells. The new finds still do not point to specific cults, al. though female deities could be appropriate for both. Figurines from the Lower Sanctuary may refer to Cybele, but identification remains at best tentative.

"Seventh-century B.C. pottery had been found in mixed contexts by Blegen in both the Upper and Lower Sanctuaries. In 1994, this was for the first time recovered from stratified contexts in a sounding below the Archaic surface in the Lower Sanctuary, together with the gray and tan wares characteristic of Troy VIII. Close study of these gray and tan wares in 1994 underlined the fact that they are virtually indistinguishable from similar fabrics in Troy VII an indication that the two may signify a tighter chronological range than previously thought (a re dating proposed too by D. Hertel in Studia Troica 1). A sounding beside the North Building also produced a Protogeometric stratum directly overlying a Troy 
VII:2 deposit, a sequence that would suggest a similar sequencing of the two phases. A cache of five bronze fibulae dating to ca. 700 B.C., although found in mixed fill, promises more evidence for the Early Iron Age in this sector in future seasons.

"An ancillary benefit of the Lower City Bronze Age project to examine the Troy VI ditch was the investigation of this area's later phases. An Early Hellenistic stone structure, although much disturbed by later constructions, was found to be aligned with the street grid. This urban plan was thus perhaps already in place centuries before the Roman period to which it has been attributed. A nearby well was emptied of nearly $17 \mathrm{~m}$ of fill dating from the midsecond century B.C. to the mid-first century A.D. In another area a limestone quarry was discovered, which appears to have supplied the Hellenistic city with building material. The area above it may have become residential in later years, as indicated by another well in use during the third century A.D. on the evidence of pottery and especially coinage. Into it had been tossed a gilded terracotta Cybele, and a marble version of similar size and type (fig. 41), whose Archaic roots have recently been illustrated at Phocaea. The southwestern corner of the LB Lower City, in contrast, does not seem to have been reoccupied until the Late Byzantine period, when it functioned first as a cemetery, later as a storage area with large pits cut into bedrock, and finally as a field in Early Ottoman times."

Interim reports on the 1993 season have appeared in Studia Troica 4 (1994) 75-104; for 1994, see Studia Troica 5 (forthcoming).

Assos. Ümit Serdaroğlu devoted the 1994 campaign to excavating sectors in the necropolis outside the city gate, and in the residential district on the terrace overlooking the gymnasium. He also carried out a regional survey.

Smintheon. The program of cleaning, restoration, and soundings in the Apollo temple continued the pace of previous seasons under the direction of Coşkun Özgünel, in whose honor an appreciative Gülpınar municipal council has renamed the street leading to the sanctuary. The stereobate has been completely cleared of overlying deposits, which contained, among other architectural debris, two fragmentary entablature blocks that appear to be window frames. Soundings around the stereobate revealed a stretch of fourth-century B.C. header-andstretcher masonry that should belong to an earlier version of the building.

\section{Propontis, Bithynia, Thrace, Pontus}

Cyzicus. Abdullah Yaylalı and his assistants spent

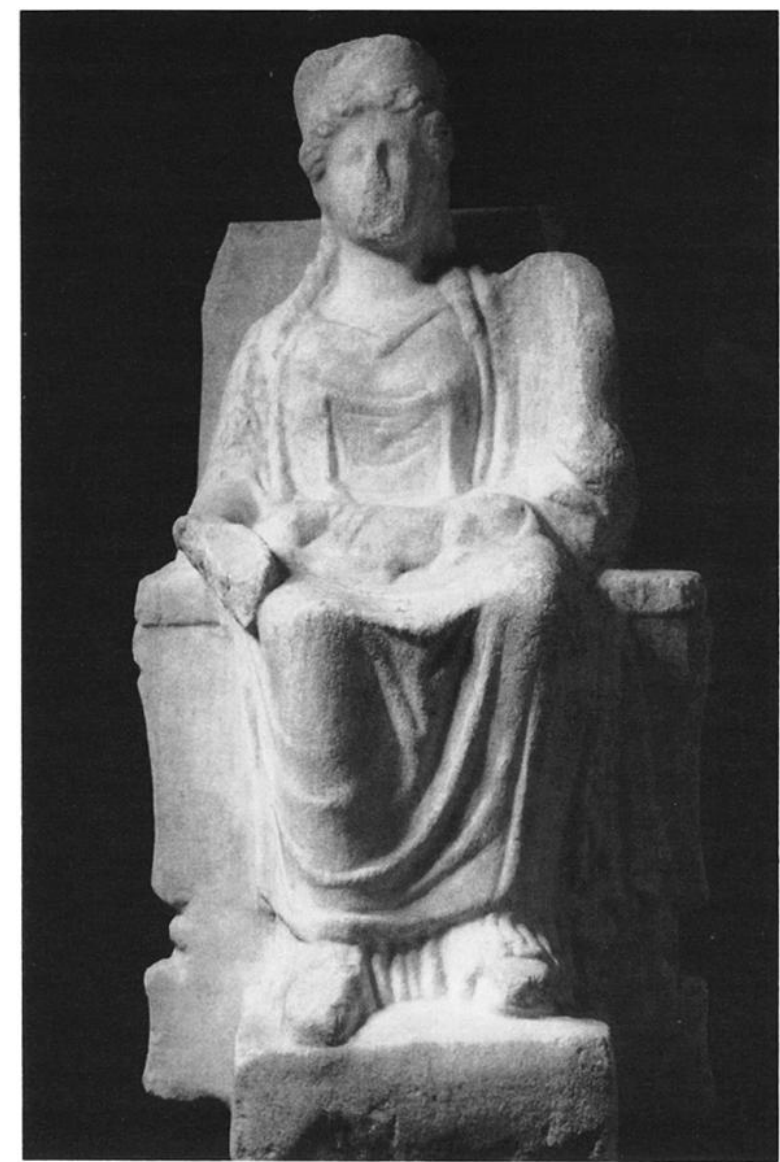

Fig. 41. Troy. Lower City. Marble statuette of Cybele. (Courtesy C.B. Rose)

the 1994 season inventorying more of the colossal Temple of Hadrian's disiecta membra, which include unfinished drums for the columns that once stood to a height of $17 \mathrm{~m}$. Continuing survey of the associated city extended to the theater and the Metroön, where Roman female statuary was found. An illus. trated report on the 1993 results appears in KST 16:2 (1995) 107-30.

Iznik. In a 15th season of excavations in the theater, whose construction had apparently already begun during Trajan's reign, Bedri Yalman freed the entire width of the stage building from its massive overburden of reuse. The stage building housed a stable in the Medieval period, with tethering holes drilled into many of the marble facade blocks. The splendid collection of glazed vessels excavated in the stratified sequence of ceramic workshops that occupied this area in Byzantine and Ottoman times will be presented in a forthcoming thesis. The 1992 season is discussed in KST 15:2 (1994) 425-54.

Ainos-Enez. Sait Başaran, who has inherited the directorship of the Ainos project, widened and deep. ened the stratigraphic sounding on the acropolis 
down to bedrock. The occupational sequence began in the sixth century B.C. with many diagnostic Aegean and East Greek wares, and was maintained without interruption into the Hellenistic period. The acropol is was then abandoned until the Byzantine era. On the eastern side of the modern city, excavations in the classical necropolis followed immediately on the heels of clandestine diggers, whose approach - while systematic-requires less time and thus outstrips formal research at an alarming pace. The project also progressed in its long-term program of restoring Enez's Byzantine and Early Ottoman monuments. The 1992 report appears in KST 15:2 (1994) 455-73. $M$. Tunay's research on the Byzantine frescoes in the Haghia Sophia church is published in AraşST 11 (1994) 521-25.

Zeytinlik/Sinop, Demirci. A comprehensive project to investigate the Black Sea amphora industry and its center in the Sinop region followed up on the 1993 survey (see AJA 99 [1995] 246-47) with excavations in 1994 at two workshops: Zeytinlik, in an eastern suburb of modern Sinop, and Demirci, 18 $\mathrm{km}$ to the south. Dominique Kassab Tezgör, French Institute of Anatolian Studies, Istanbul, and her collaborators Yvon Garlan and Ismail Tatlıcan (director of the Sinop Museum) kindly provide the follow. ing report:

"The kiln site at Zeytinlik represents the earlier of the two excavated workshops, which between them span the Hellenistic and Roman periods to Early Byzantine times. It was exposed and damaged by the foundation cut for a housing project in 1992 and 1993, and excavation was thus restricted to salvage investigations on a single kiln. The workshop was established on bedrock that had been cut back by quarrying. Shortly thereafter, a large piriform kiln constructed with reused tiles and clay began to manufacture primarily amphoras and tiles: stamps found in the kiln and bearing the name of the producer Sosias date it to $300 / 290$ B.C. Associated pottery, and many wasters, indicate that the kiln remained active for one century. Stamped examples numbered 169 (all from Sinop with the exception of three Rhodian types), including a few tiles impressed with the same seals used on the amphoras. Of particular significance is the large proportion of stamps relative to the number of amphoras recovered: roughly $80 \%$, in contrast to the $17-20 \%$ proposed in earlier studies. After the workshop ceased production, no doubt in the upheaval caused by Pharnaces's conquest of Sinop in 183 B.C., the area remained essentially unoccupied until the Late Ottoman period.

"At Demirci, excavations were carried out in one of several anomalies recorded by geomagnetic survey, along the site edge that was threatening to collapse and be destroyed. It proved to be a dense area of stratified kilns and related installations such as wells and storage areas. Unlike the Zeytinlik workshop, where production was limited to heavy potting, this center made a few varieties of tableware and lamps along with cooking pots, tiles, and amphoras. The kilns were adapted to this industry: the earliest (second century B.C.) and the best preserved, an oval $2.4 \times 2 \mathrm{~m}$ with two central supports, contained over 20 tubes to diffuse the heat and support the more fragile vessels during firing. It was abandoned and replaced by a shallow well at the end of the Hellenistic period, until a second kiln was assembled here (second century A.D.) and enclosed in a stone platform to retain heat. This kiln was again replaced two or three centuries later by a well. The amphora industry sampled in the preceding year's survey is now confirmed through stratified finds. A few new types were previously known from the northern shore of the Black Sea, at the sites to which they were exported. Finally, although the 1994 excavations focused on Demirci's later ceramic industry, the site's long involvement in this speciality is attested 300 $\mathrm{m}$ to the north, where a fourth-century B.C. workshop has been identified."

For the 1993 survey, see AraşST 12 (1995) 177-90; Y. Garlan discusses Sinop amphora stamps in CRAI 1990, 492. The neighboring Byzantine site of Çiftlik is summarized below, under Byzantine Period: Çiftlik/Sinop.

Şamlar necropolis/Amasya. Further examples of the barrel-vaulted communal tombs used by modest Late Roman inhabitants of Amasya were excavated by Metin Özbek in a second salvage season in 1994. Samples taken from construction timber may place the cemetery in an absolute dendrochronological framework. Previous findings are reported in $K S T$ 16:2 (1995) 95-105.

\section{Phrygia}

Aizanoi. Klaus Rheidt and his team devoted the 1994 season to restoration projects in the porticoed street and at the Roman baths; to organizing the excavation's large collection of reliefs and inscriptions from the site and its vicinity; and to pre-publication study. Progress reports for 1992 and 1993 can be found in KST 15:1 (1994) 515-37 and 16:2 (1995) 57-73; for 1994, see $A A 1995$ (forthcoming).

Pessinus. The 1994 season directed by John Devreker progressed on the combined fronts of excavation, geophysical prospecting, and intensive regional survey that have characterized the past several campaigns. Excavations again focused on the 
city center. Trenches north of the temple, which was built under Tiberius for the imperial cult, and uphill to the east, confirmed the existence of a Middle/Late Phrygian (seventh-mid-sixth century B.C.) domestic level as the earliest occupation. Beyond the temple to the north, a possible defense wall of Early Hellenistic date and a massive sunken foundation were overlaid in the second/first century B.C. by a large building with black-and-white mosaics, already partly encountered by Lambrechts in earlier excavations. Because this area was badly disturbed by Byzantine quarrying for building materials, there remains unfortunately little of its Roman phase.

Survey and GIS analysis traced $7 \mathrm{~km}$ of the northern aqueduct's terracotta pipes, and found possible evidence for a Roman dam in a high valley at the far end. A second water supply was tapped at a source $8 \mathrm{~km}$ to the northeast. Four more Roman cemeteries were located, in the vicinity of their villages and farm. steads. A report on the 1993 season appears in KST 16:2 (1995) 75-94.

Ankara. The demolition of a large commercial building in the city's old Ulus district gave unprecedented access to Ankara's pre-Republican history. Excavations carried out in 1995 by the Ankara Archaeological Museum and Cevdet Bayburtluoğlu reviewed here the entire sequence of periods from Ottoman to Phrygian times, with especially substantial Roman and Hellenistic phases. The most impressive remains were a well-paved Roman street oriented $n-s$ and exposed for a length of $69 \mathrm{~m}$, neighboring structures with marble floors, and a Roman female statue in marble. Classical, Archaic, and Phrygian pottery, without associated architecture, dates the earliest occupations founded on sterile soil. An illustrated report has been published in the Museum of Anatolian Civilization's Museum News 6 (1995) 5-6.

Hierapolis. The previous years' vigorous pace of research and restoration was maintained by Daria De Bernardi Ferrero in 1994. Excavations in the agora and on Frontinus Street uncovered and reerected more of their columned porticoes. Restoration continued in the Apollo temple, the theater, and the Medieval fortress. The project begun in 1993 in the northern necropolis added four new tombs to the over 100 already inventoried: these masonry hypogea were conceived as houses to contain sarcophagi, including one Sidamara type. For the 1992 and 1993 seasons, see KST 15:2 (1994) 341-50 and 16:2 (1995) 345-60.

\section{Cilicia}

Cumhuriyet Square-Tarsus. Salvage investigations continued for a second season in the municipal square in the center of Tarsus, where bulldozing for a parking lot had uncovered the paved street of a much older municipal project. Levent Zoroğlu and his associates devoted the 1994 campaign to stratigraphic soundings around the 65-m stretch exposed the previous year, in order to determine its chronological parameters. The 1.5-m-deep road foundations, carefully set on a bed of sand with a sunken drain, were found to overlie a Middle Hellenistic building level. It can now be concluded that the street was laid out as part of an Early Imperial Roman urban reorganization in the first century B.C.learly first century A.D. The street was stabilized again with limestone paving blocks in Late Roman times. It was probably no longer functioning by the Medieval period, when the portico columns were retrieved for private housing. The archaeologists hope to persuade the local council to establish an open-air museum here.

Donuktaş-Tarsus. Nezahat Baydur assesses her 10th and final excavation season in 1992 at the colossal Imperial Roman temple on the outskirts of the modern city in KST 15:2 (1994) 225-41.

Kelenderis. After a decade of excavations in Rough Cilicia's best harbor and Anatolia's closest maritime link with Cyprus, Levent Zoroğlu spent the 1994 season conserving the 15-m-long Late Antique mosaic for in situ display (see AJA 99 [1995] 249, fig. 33 ); and restoring several of the town's Ottoman monuments. For the 1992 season, see KST 15:2 (1994) 189-209. The first in the final report series has appeared: L. Zoroğlu, Kelenderis I: Kaynaklar, Kalıntılar, Buluntular (Ankara 1994).

Karasis. Mustafa Sayar discusses and illustrates this well-preserved Seleucid fortress, perched high above AnavarzalAnazarbos in northeastern Cilicia, in AntW 26:4 (1995) 279-82. Recent installments of his annual epigraphic surveys in this region can be found in AraşST 11 (1994) 137-60 and 12 (1995) 39-60.

Küçük Burnaz. This anonymous ancient harbor in the northeasternmost tip of the Mediterranean remained invisibly buried in coastal dunes until 1987, when a local company began to bulldoze the site for sand and revealed buildings standing as high as $10 \mathrm{~m}$. A thorough survey, carried out in 1994 by Jennifer Tobin, recorded some 20 identifiable structures and placed their chronological range between the first century B.C. and the 13th century A.D. The site was laid out on a roughly $500 \times 500 \mathrm{~m}$ cardinal grid, perhaps as the port for inland Epiphaneia/Güzelhan when Pompey resettled Cilician pirates there in 67 B.C. Much of the architecture, however, suggests that the site saw its greatest development in Late Antiquity; it may have profited from its location on the 
Pilgrim's Road as an inviting stop for weary travel. ers. The best preserved of the buildings exposed in the city center was connected to an aqueduct, and displays the necessary furnishings of a public bath: chambers lined with waterproof cement, hypocaust tiles, and elaborate piping. Other large structures are still contained within intact dunes. The site is now protected by a fenced enclosure generously con. tributed by a nearby industrial center. For mention of the site in previous surveys, see AraşST 10 (1993) 391 and ArkST 8 (1993) 357-67.

Porsuk. For the Roman period, see above under "Chalcolithic and Bronze Age: Eastern, Northern, and Central Anatolia."

\section{Southeast Anatolia}

Zeugma. Reports by David Kennedy on his 1993 preliminary season at Belkis/Zeugma appear in KST 16:2 (1995) 207-15, Archaeology 48:2 (1995) 54-55, and AnatSt 44 (1994) 18-20. No formal excavations were carried out in 1994.

\section{BYZANTINE}

Istanbul. The struggle to record, preserve, and celebrate the monuments of this city's past in the face of unprecedented urban growth achieved sev. eral major victories in the past year, to offset the by now familiar chronicle of destruction. The follow. ing report was kindly prepared by Mehmet Tunay, Istanbul University:

“This year's most celebrated moment for Byzantine studies was the long-awaited opening of the Archaeological Museum's new Byzantine wing in June 1995, together with an exhibit entitled "Istanbul through the Ages," where finds from excavations at the city walls, the Hormisdas Palace, and the churches of St. Polyeuktos and Constantine Lips take pride of place. It is also significant that an independent national commission has declared the entire historic district of Istanbul a protected zone. All building projects will be required to obtain clearance from designated authorities, and will proceed under close supervision in the case of archaeological findings. These regulations should prevent the repetition of disasters like those that affected the Bodrum Camii, the Hippodrome, the Forum of Constantine, and-more recently-the Magnaura.

"The pattern of recent years urgently needs interrupting. As a result of the 1994 municipal elections, all restoration work on the city walls has ceased, as have related projects on the Hormisdas and Mangana Palaces (fortunately for the cisterns of the St. George monastery at Mangana, only after the debris accumulating there since the excavations of the 1920s had been cleared out). Building projects on the city outskirts damaged elements of three Byzantine summer residence complexes: in the Aretas of Romanus IV Diogenes on the European side; and on the Anatolian side, a bath near the Damatris complex at Samandra, and walling west of the main Bryas complex at Küçükyalı. The year's most spectacular accidental discovery occurred in the Kocamustafapaşa district, inside the city walls on the Sea of Marmara. A foundation cut there came down on two intact sarcophagi, and below them, on a large figural mosaic (fig. 42) from the floor of what must have been a wealthy villa."

E. Yücel's restoration work at Haghia Sophia is discussed in ArassT 11 (1994) 1-8 and MKKS 5 (1995) 171-74. The Silivrikapı Mausoleum (erroneously identified as such in AJA 99 [1995] 250, fig. 34) has been published by J.G. Deckers and Ü. Serdaroğlu in JAC 36 (1993) 140-63.

Great Imperial Palace, Istanbul. In 1994 E. Bolognesi Recchi-Franceschini concentrated her third survey season on the juncture between the upper Constantinian palace and the lower Justinianic one, in the area of the great peristyle hall (site of the Mosaic Museum: see below). She now dates the construction of Mamboury DB - perhaps a church - to the same period as the peristyle, whereas Mamboury DC would represent a later phase in the palatial complex's history. A report on the first (1992) season appears in ArassT 11 (1994) 19-34.

Great Imperial Palace/Mosaic Museum, Istanbul. The restoration of the Mosaic Museum, in the Justinianic palace's peristyle court and its northeastern hall, was revived and is nearing completion thanks to a joint Austrian-Turkish project directed by W. Jobst and B. Erdal. The museum project, conservation, and study of the mosaics (excavated in the 1930s and 1950s) are discussed in ArassT 11 (1994) 9-18. New soundings, carried out in three sectors of the northeastern wing to determine more closely the stratigraphic setting of the mosaics, confirm that they were installed in the first decades of the sixth century, when the palace was restructured and restored.

Anastasian Wall Project, Thrace. A survey to map and analyze the $50 \mathrm{~km}$ circuit of long walls, constructed in the early sixth century by Anastasius I (A.D. 491-518) between Karacaköy on the Black Sea and Silivri on the Sea of Marmara, was carried out in 1994 by James Crow. Although the northern end has eroded into the sea, the other parts of the defensive system - ditch, walls, gates, rectangular towers, and possibly pentagonal towers - have been well protected and preserved by vegetation. It is suggested 


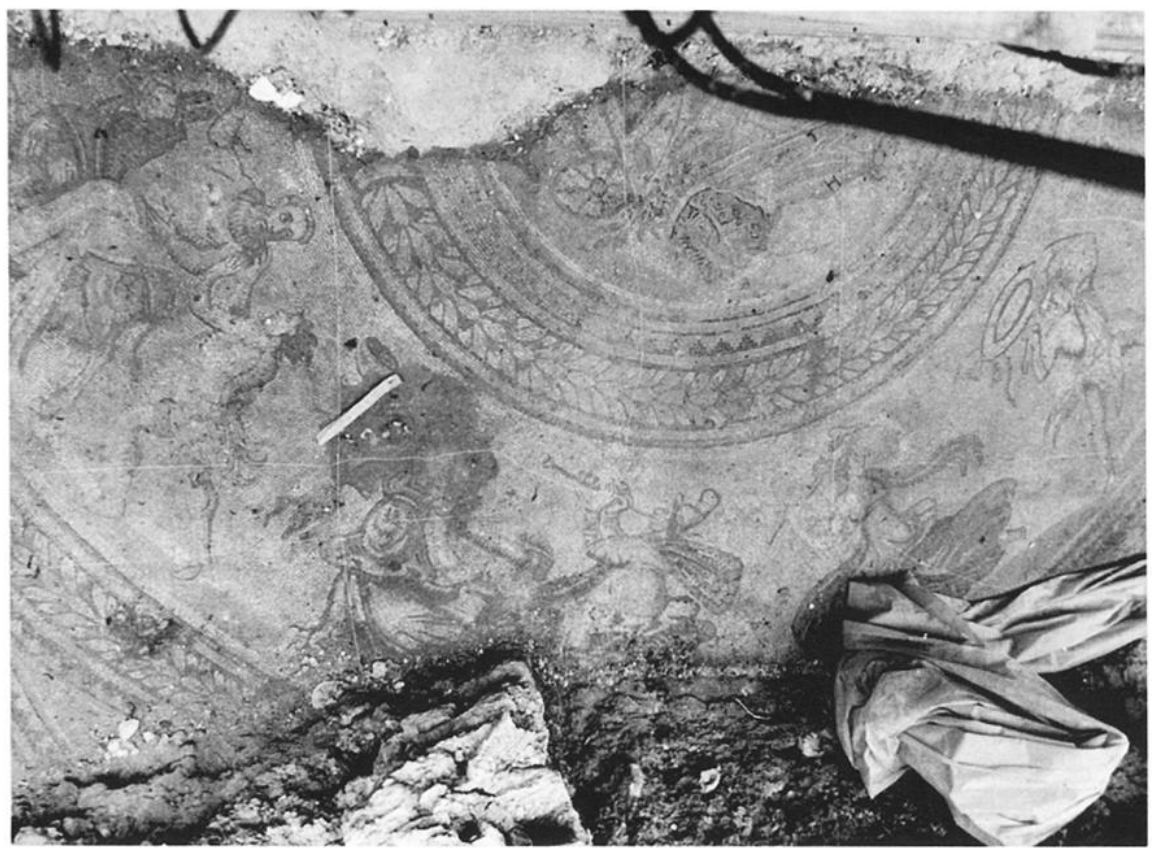

Fig. 42. Istanbul. Kocamustafapaşa district: mosaic from a Byzantine villa. (Courtesy M.I. Tunay)

that the walls may have been constructed to safeguard the preexisting aqueduct system, of which many sections are still visible in this area. The long walls functioned for 150 years, after which Constantinople fell back on its city fortifications for protection. A summary appears in British Institute of Archaeology/Ankara Research Reports 1994, 18. For the aqueduct survey conducted in the 1950 s by F. Dirimtekin, see CahArch 10 (1959) 215-43. J. Crow has published a pre-survey study of the walls in C. Mango and G. Dagron eds., Constantinople and Its Hinterland (Cambridge 1995) 109-24.

Ainos-Enez. See above, under "Classical: Propontis, Bithynia, Thrace, Pontus."

Cyzicus-Iznik-Geyve Survey. The fifth and final season of a multidisciplinary project to record the human and natural geography of this province (Roman Bithynia) in Roman, Byzantine, and Ottoman times extended its survey from Gemlik east to the Sakarya River. Project directors Véronique François, Bernard Geyer, and Jacques Lefort combined their fields of archaeology, geography, and history to assess the complexities of the Iznik lake, whose level has fluctuated over $4.5 \mathrm{~m}$ in historic times because of climate and human intervention; followed the regional network of Byzantine routes and associated settlements; and evaluated the diachronic effects of heavy erosion. A report on the Bursa area (1992 survey) has been published in ArassT 11 (1994) 65-71. J. Lefort discusses the Byzantine road systems in C. Mango and G. Dagron eds., Constantinople and Its Hinterland (Cambridge 1995) 207-18. The final report is planned for 1996-1997.

Ereğli-Marmara. The salvage excavations at the Middle Byzantine Basilica at Perinthos, with wellpreserved mosaics, are reported by M. Akif Işın in MKKS 5 (1995) 27-37.

Gaziköy-Tekirdağ. Nergis Günsenin shifted her investigations in 1994 from the Byzantine amphora manufacturing center of ancient Ganos to shipwrecks off the Marmara coast, and an amphora workshop on the island of Marmara. She discusses her 1993 results in ArkST 10 (1995) 201-20.

Kurşunlu/Gemlik-Bursa. In 1995 Mehmet Tunay began the cleaning and restoration of the 12thcentury monastic Church of St. Abercius.

Ulubey/Uşak Survey. In the third installment of a five-year project to record Byzantine castles along the Aegean coast, Mark Whittow turned south of Uşak to the fertile Banaz plain, whose agricultural prosperity in Roman and Byzantine times was well illustrated by N. Firatli's excavations of the church at Sivasl1. The 1994 survey focused on the large castle that dominates a canyon $2 \mathrm{~km}$ south of Ulubey. The castle's relatively poor preservation, mainly at foun. dation level, in fact proved useful in revealing its many phases of construction alternating with periods of neglect. It may originally date to the seventh/eighth centuries, then fell out of use during the two centuries of Byzantine economic expansion that pre- 
ceded the defeat at Manzikert in A.D. 1071. The castle was then reactivated in a second building stage, which made use of Roman spolia for the repair and expansion of the towered enclosure, before being abandoned and revived yet again in the 13 th century. Since written sources are few for this region, the archaeological evidence takes on primary importanceparticularly for the poorly understood transition from Byzantine to Turkish control. Whittow's report for the 1993 Ödemiş survey can be found in AnatSt 44 (1994) 187-206 (with H. Barnes).

Heraclea Pontica. For inscriptional material, see L. Jonnes ed., The Inscriptions of Heraclea Pontica (Inschriften griechischer Städte aus Kleinasien 47, Bonn 1994).

Ciftlik/Sinop. Urgent salvage work to record the Byzantine and earlier site at Çiftlik, south of Sinop, before it erodes further into the sea, was carried out in 1994 by Stephen Hill in cooperation with the Sinop Museum. Excavation efforts concentrated on the Early Byzantine church with a square nave and fine mosaic floors, which show several phases of repair. It may have been associated with an agricultural estate and a monastic community. Earlier settlements are indicated by Bronze Age artifacts. The mosaics have been lifted and taken to the Sinop Museum. A preliminary report on the 1993 survey appears in British Institute of Archaeology/Ankara Research Reports 1994, 3-5; and AnatSt 44 (1994) 15-16.

For the nearby amphora factories at Demirci $(1 \mathrm{~km}$ distant), see above, under "Propontis, Bithynia, Thrace, Pontus: Zeytinlik/Sinop, Demirci."

Trabzon-Gümüşhane Survey. James Crow extended his survey area in 1994 from the Arakl1. Trabzon-Maçka region of the two previous seasons toward the south and Gümüşhane, in order to dis cover the Byzantine communications network linking communities, monasteries, and fortresses across a highly irregular and difficult terrain. For the 1993 survey, see AnatSt 44 (1994) 16-18.

Amorium. The seventh (1994) excavation season progressed in the Lower City's two ongoing areas of investigation, the church and the southwestern gate, as well as on the northern side of the Upper City mound. Survey in the northern foothills of the Emirdağ Mountains also documented the intensive Roman and Byzantine exploitation of the hinterland connected to this regional urban center. C.S. Lightfoot kindly provides this assessment:

"Excavations in the church concentrated on uncovering the floor in the bema and naos, with much new evidence for the occupational history of the building. Two major construction phases are now clearly attested, rather than three as previously thought: the primary phase of the Late Antique aisled basilica, followed by extensive remodeling, perhaps in the second half of the ninth century, when the building was transformed into a cross-domed basilican church. This restructuring involved the addition of massive internal pillars to support a domed roof, and a radical alteration of the church's furnishings. Thus, two distinct levels of the opus sectile pavement in the bema can now be understood in connection with this phasing. The location of the high altar in the middle of the bema floor was also identified thanks to fragments of the altar base still in situ. Precise evidence for secular reuse of the church in the 13th century, dated by three coins issued by the Seljuks of Rum, was concentrated in the eastern end where the apse and its superstructure must have better survived the church's destruction. Archaeobotanical samples and carbonized sheep droppings indicate that the structure was used as a farmyard for agricultural produce and animal husbandry.

"Work on the Lower City fortifications focused on the gateway west of the triangular tower, which - late in its history-had been blocked by a crude stone wall at its northern, inner end. The wall was assembled from reused blocks, including a keystone decorated with a raised cross medallion, and probably dates to the 11th century like other rubble dwellings constructed inside the gate. At the outer end of the gateway, the horizontal lintel blocks were still lying in a row across the entrance (fig. 43). A coin from the surface immediately below the collapse indicates that the gateway was still standing until the last quarter of the 10th century. The lintel's interlocking blocks recall W.J. Hamilton's description of an arch still visible in 1836, when he conclusively iden. tified this site as Amorium.

"In the Upper City, a second season in the northern slope step trench did much to clarify the chronology and stratigraphy of the latest defensive system, which involved cutting back the mound to create a steeper rampart and the construction of a substantial fortification wall. A new $30 \cdot \mathrm{m}$ trench inside the fortifications exposed a range of Late Seljuk and Early Ottoman features and surfaces, including a room with fallen roof beams. These deposits, which represent the final stages of permanent occupation in the 14th and 15th centuries, reflect the decline of the site under the Seljuks, and Amorium's transformation from a major Byzantine fortress city to a rustic backwater. The archaeological findings from this part of the Upper City, together with historical and demographic documents, and environmental analysis, should provide a unique glimpse into the life of a rural community in the Late Medieval period."

Reports for 1994 can be found in AnatSt 45 (1995), 


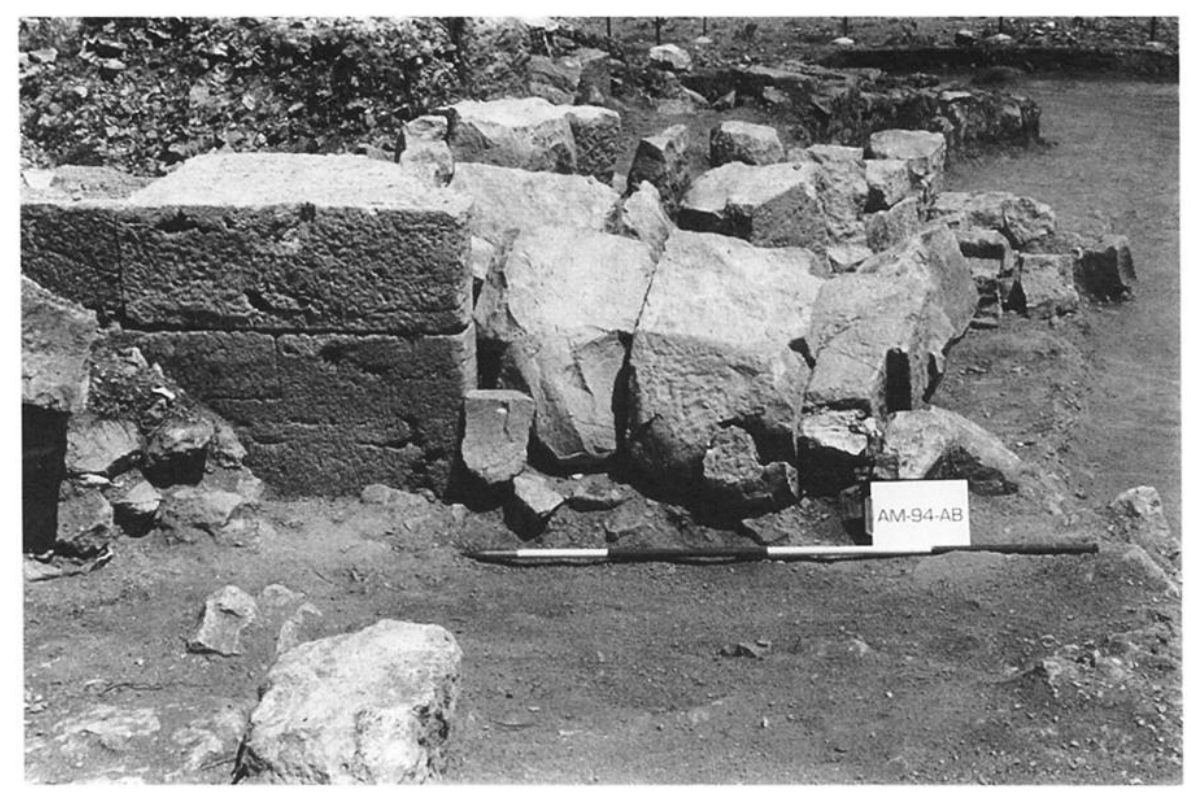

Fig. 43. Amorium. Lower City gate: collapsed lintel. (Courtesy C.S. Lightfoot)

and British Institute of Archaeology/Ankara Research Reports 1994, 8-11; for 1993, see AnatSt 44 (1994) 105-28 and KST 16:2 (1995) 131-51.

Çatalhöyük. For the Byzantine remains, see above, under "Later Neolithic."

Çanlı Kilise-Akhisar. Although the Çanlı Kilise is usually cited in handbooks as an example of Constantinopolitan style imported to provincial Cappadocia, it has received little architectural study since Gertrude Bell's brief visit in 1906. Robert Ousterhout, University of Illinois at Urbana-Champaign, kindly offers a summary of his first three-week survey season to document more fully the church and its surrounding village:

"Much of our effort in 1994 was directed to the preparation of a new plan, elevations, and sections of the elegant brick and stone church (fig. 44), usually dated because of its frescoes to the 11th century with a few later additions. Its naos was constructed with exceptional care, the dome's diameter measuring nearly 15 Byzantine feet and half the width of the naos, in contrast with less exacting attention paid to other sections of the building. Of particular interest is the use of brick almost exclusively as facing material, thus a veneer imitating techniques in the capital without affecting the local tradition of mortared rubble and especially stone.

"We also wanted to situate the church within its architectural landscape - a settlement extending to the east and west over perhaps $2 \mathrm{~km}$. We were able to survey a $100 \times 250 \mathrm{~m}$ area around and east of the church, and draw a plan of its rock-cut building remains and topographic features. Four distinct areas were located here, comprising two so-called courtyard monasteries, three small churches, one of several cemeteries at the site, and two chamber complexes arranged in rows. The season's surprise came with the discovery of two 'underground cities' connecting to one of the rock-cut churches. The entrances were protected by an elaborate series of rolling stone doors; and, although they appear to follow a village scale, some of the rooms are exceptionally large (one measuring $35 \mathrm{~m}$ long) in comparison with the more famous examples in eastern Cappadocia. They certainly served as refuges, since they are linked to buildings above ground. It is particularly significant that they would date, like the village, to the 10 th-12th centuries, well after the time of the Arab invasions usually cited for other underground cities.

"The nature of this settlement (and others like it in the region) must also be reevaluated. Rather than being strictly monastic, it may well represent a typical Byzantine town, with houses of varying sizes, barns, and stables, coexisting with a few monasteries. This issue will require a fuller documentation of the site in future seasons."

Cappadocian Underground Cities Survey. A typological study of the multilevel underground refuges and villages that characterize the Cappadocian highlands was carried out for a fourth season in 1994 by Roberto Bixio with a team of speleologists. They have located 172 such settlements in the broad area between Yozgat, Niğde, and Aksaray, and recorded a wide variety of architectonic systems, some of them previously unknown. Particular attention is being given to the hydraulic and drainage tunnels that tapped underground streams for the settlements and their fields, as well as to converse techniques for di- 


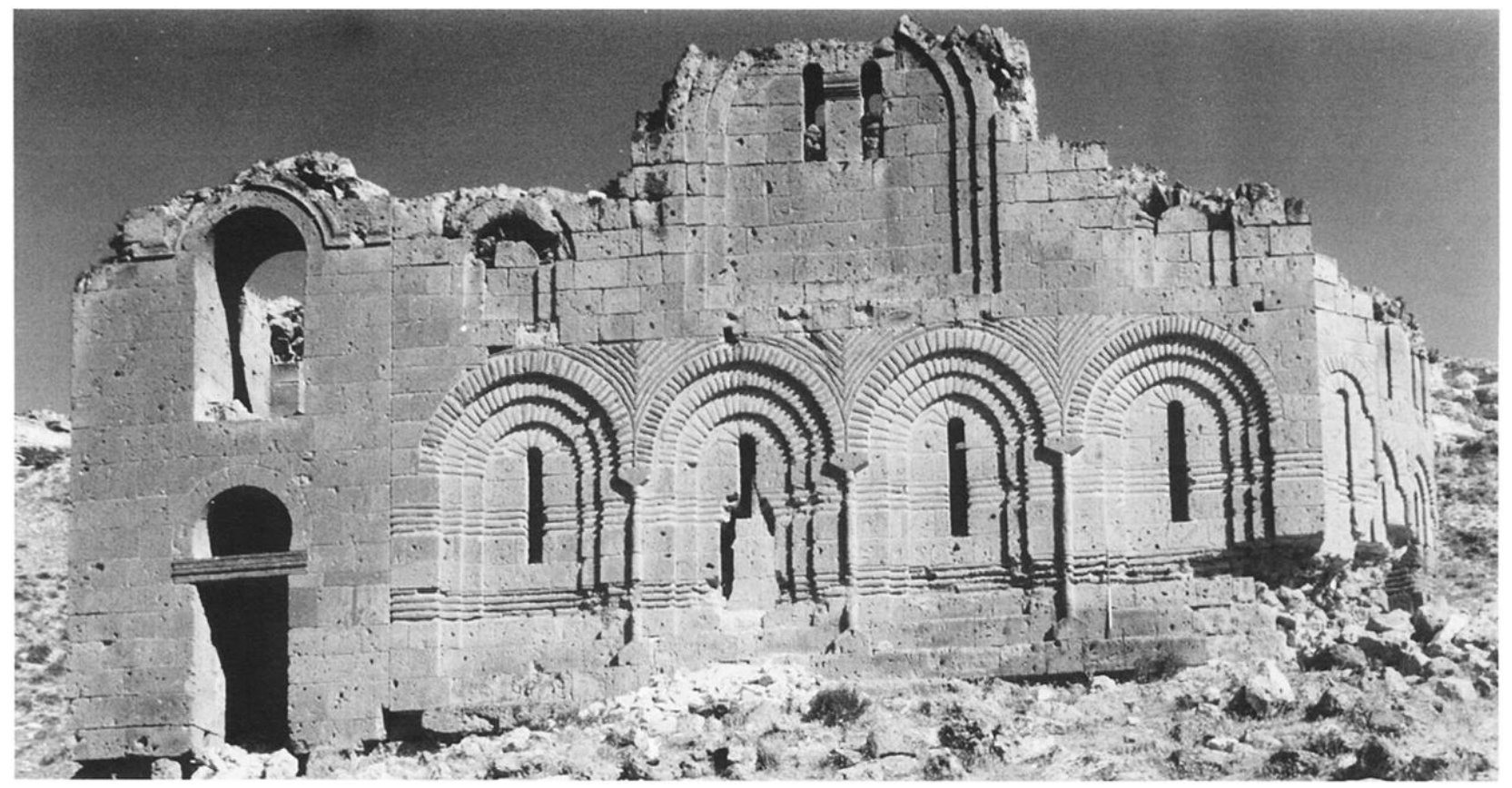

Fig. 44. Çanlı Kilise-Akhisar. Church from the south. (Courtesy R. Ousterhout)

verting and storing excess rainwater. A report on the first two seasons is published in ArassT 11 (1994) 43-56.

Akören (northern Cilicia). This sixth-century A.D. site $50 \mathrm{~km}$ north of Adana in the upper Seyhan valley recalls the "dead cities" of northwestern Syria both in its architecture and remarkable state of preservation. Gabriele Mietke, during a first 1994 survey, focused her attention on two of its churches (one with figural sculpture) and a mausoleum. For inscriptions, preliminary photographs, and comparable sites in the region, see M.H. Sayar's 1993 survey notes in ArassT 11 (1994) 137-60.

Kilise Tepe. For the Byzantine period, see above, under "Chalcolithic and Bronze Age: Eastern, Northern, and Central Anatolia."

Gemiler Island/Fethiye Survey. The extensive Medieval colony on the Lycian coast and offshore islands was investigated for a fifth season in 1994 by Shigebumi Tsuji with Kazuo Asano. The project's painstaking documentation of pilgrimage centers, necropolises, and churches, many with well-preserved wall paintings, has appeared in a first preliminary report edited by S. Tsuji: The Survey of Early Byzantine Sites in the Ölüdeniz Area (Memoirs of the Faculty of Letters, Osaka University 25, Osaka 1995). The 1993 season is summarized by $\mathrm{K}$. Asano in AraşST 12 (1995) 407-19.

Demre. In 1994, Yıldız Ötüken's excavations inside the church of St. Nicholas proceeded to its interior arcade and podium sector. Architectural finds include opus sectile flooring from the eighth-century, second building phase, and carved arcades with Constantinopolitan features. The exterior arcade and its neighboring street are now completely exposed. Pottery, including Cypriot types, spans the sixth to the 11th century. Restoration work on the church's frescoes continued. For the 1992 and 1993 progress reports, see KST 15:2 (1994) 475-86 and 16:2 (1995) $361-75$.

\section{ISLAMIC}

The following site summaries were generously prepared by Scott Redford, Georgetown University.

Alanya Citadel. In the course of the 1994 excavations, Oluş Arık uncovered an eyvan, thought to be the royal audience hall of the Seljuk palace. This open hall, facing the innermost courtyard of the palace, was flanked by two rooms whose entrances have yet to be identified. The remains of piers indicate that it was also fronted by a portico. This architectural schema recalls the larger palace at Kubadabad, as do underglaze painted tiles (eight-pointed stars, cruciform ones, and tile mosaics). Two tiles remained in situ on the courtyard facade. The 1992 season is presented in KST 15:2 (1994) 579-82.

Hacı Baba Kiosk, Alanya. Scott Redford's 1994 survey resulted in a site plan of this two-story pavilion and its enclosure wall, $6 \mathrm{~km}$ from Alanya, as well as plans, sections, and elevations of the building itself. The complex can be dated to the second quarter of the 13 th century by its masonry, and by its interior and exterior geometric fresco decoration.

Kubadabad. Rüçhan Arık's 1994 season concen. 
trated on the area surrounding the smaller palace of this Seljuk-period site. The road between the larger and smaller palaces was found to run parallel with the water system. The enclosure wall and a possible fountain were also investigated. Glaze slag recovered in these areas underscores the probability that tiles were being produced locally. Soundings uncovered extensive Early Bronze remains here, but nothing of the Byzantine period attested in other sectors. Dendrochronological samples from the northern end of the larger palace give the reassuring confirmation that all its juniper pilings were cut in 1231, well within the reign of the builder, Alaeddin Keykubad. For the 1992 findings, see KST 15:2 (1994) 533-46.

Erciş Fortress (Çelebibağı). Salvage operations against the rising waters of Lake Van were continued with increased urgency by Abdüsselam Uluçam. The entire site is now under water, except for the fortress's necropolis (whose low-lying areas are also threatened). The 1994 efforts concentrated on trans. ferring the late 12 th-early 15 th century Islamic sarcophagi, tombstones, and burials - many dating to the Karakoyunlu dynasty - to the top of the hill. Despite weathering, they are often well preserved, and of a high artistic quality that will especially interest students of calligraphy. Soundings also confirmed the presence of earlier cremation burials. For the 1992 season, see KST 15:2 (1994) 487-511.

Ani. The major investigation of Beyhan Karamağaralı's 1994 campaign was a large building, perhaps a palace; its stratigraphic context and frag. mentary carved portal elements suggest that it dates to the 11th century, after the arrival of the Turks. This structure is multistoried, with two staircases. The lower floor, at basement level, must have been lit from above since no windows were found. It consisted of a room with a raised sleeping platform, a granary, and other rooms with lamp niches and hearths that may have served for storage or as stables. It is suggested that the main living areas were located on the upper story or stories.

Harran. Nurettin Yardımcı and his team focused their 1994 excavations around the Aleppo Gate, clearing the city wall on either side of it, and restoring part of the defensive wall there. They also worked on two buildings inside the gate: a vaulted structure, thought to be a granary, and what appears to be a military canteen with large ovens, a well, and a water channel. The 1992 report appears in KST 15:2 (1994) 513-32.

Aksaray. Bekir Deniz began excavations in 1994 at the building locally known as the "Darphane" or Mint, which is in fact the zaviye, or dervish lodge, of the Melik Mahmoud khan. In the process of clearing the eastern and southeastern sides of the structure, a fragmentary inscription was found that may date part of the building to A.H. 711/ A.D. 1310/11. Tiles associated with this structure, however, and its typological similarity to other zaviyes, would suggest an initial foundation in the 13 th century.

Iznik kilns. The long-term investigations of the famous Ottoman-period ceramic industry continued in 1994 under the direction of Oktay Aslanapa and Ara Altun. In the area south of the Hacı Hamza baths, workshops for tiles were discovered reinstalled inside a structure datable to the fourth century A.D. Water supply via pipes was shared with the nearby bathhouse. The team also restored several previously excavated kilns, as part of the rapidly developing but underfunded Iznik preservation zone. The 1992 season is discussed in KST 15:2 (1994) 547-63.

Ottoman kilns, Istanbul. When budgetary constraints in 1994 prevented Filiz Yenişehirlioğlu from excavating soundings in the Ottoman potters' district around the Tekfur Sarayı, she conducted an ethnoarchaeological survey of the few traditional workshops still surviving in Eyüp and other districts of Istanbul. Their kilns closely resemble those from Iznik, and the two industries were indeed linked in the later Ottoman period. Clay sources used by the current workshops will serve for comparative analysis with the historical ceramics and tiles collected during earlier surveys. A detailed report on the previous campaign appears in AraşST 12 (1995) 535-66.

\author{
DEPARTMENT OF ARCHAEOLOGY AND \\ HISTORY OF ART \\ FACULTY OF HUMANITIES AND LETTERS \\ BILKENT UNIVERSITY \\ o6533 BILKENT \\ ANKARA, TURKEY \\ GATES@BILKENT.EDU.TR
}

